\title{
Conversion of biomass to biofuels and life cycle assessment: a review
}

\author{
Ahmed I. Osman ${ }^{1}$ (1) Neha Mehta ${ }^{1,2} \cdot$ Ahmed M. Elgarahy $^{3,4} \cdot$ Amer Al-Hinai $^{5} \cdot$ Ala'a H. Al-Muhtaseb $^{6}$. \\ David W. Rooney ${ }^{1}$
}

Received: 6 May 2021 / Accepted: 9 July 2021 / Published online: 23 July 2021

(c) The Author(s) 2021

\begin{abstract}
The global energy demand is projected to rise by almost $28 \%$ by 2040 compared to current levels. Biomass is a promising energy source for producing either solid or liquid fuels. Biofuels are alternatives to fossil fuels to reduce anthropogenic greenhouse gas emissions. Nonetheless, policy decisions for biofuels should be based on evidence that biofuels are produced in a sustainable manner. To this end, life cycle assessment (LCA) provides information on environmental impacts associated with biofuel production chains. Here, we review advances in biomass conversion to biofuels and their environmental impact by life cycle assessment. Processes are gasification, combustion, pyrolysis, enzymatic hydrolysis routes and fermentation. Thermochemical processes are classified into low temperature, below $300{ }^{\circ} \mathrm{C}$, and high temperature, higher than $300{ }^{\circ} \mathrm{C}$, i.e. gasification, combustion and pyrolysis. Pyrolysis is promising because it operates at a relatively lower temperature of up to $500{ }^{\circ} \mathrm{C}$, compared to gasification, which operates at $800-1300{ }^{\circ} \mathrm{C}$. We focus on 1) the drawbacks and advantages of the thermochemical and biochemical conversion routes of biomass into various fuels and the possibility of integrating these routes for better process efficiency; 2) methodological approaches and key findings from 40 LCA studies on biomass to biofuel conversion pathways published from 2019 to 2021; and 3) bibliometric trends and knowledge gaps in biomass conversion into biofuels using thermochemical and biochemical routes. The integration of hydrothermal and biochemical routes is promising for the circular economy.
\end{abstract}

Keywords Biomass $\cdot$ Biofuel $\cdot$ Thermochemical $\cdot$ Biochemical $\cdot$ Life cycle assessment

Ahmed I. Osman

aosmanahmed01@qub.ac.uk

$\bowtie$ Amer Al-Hinai

hinai@squ.edu.om

$\triangle$ Ala'a H. Al-Muhtaseb

muhtaseb@squ.edu.om

1 School of Chemistry and Chemical Engineering, Queen's University Belfast, Belfast, Northern Ireland BT9 5AG, UK

2 The Centre for Advanced Sustainable Energy, David Keir Building, Queen's University Belfast, Stranmillis Road, Belfast, Northern Ireland BT9 5AG, UK

3 Environmental Science Department, Faculty of Science, Port Said University, Port Said, Egypt

4 Egyptian Propylene and Polypropylene Company (EPPC), Port-Said, Egypt

5 Department of Electrical and Computer Engineering, College of Engineering, Sultan Qaboos University, Muscat, Oman

6 Department of Petroleum and Chemical Engineering, College of Engineering, Sultan Qaboos University, Muscat, Oman

\section{Introduction}

In recent decades, urbanisation, modernisation and industrialisation linked to energy production and utilisation have been a fundamental loop in various economic, scientific and social sectors (Ahmad Ansari et al. 2020; Shrivastava et al. 2019). The depletion of non-renewable fuel sources, accompanied with greenhouse gas emissions, has become a critical issue (Fawzy et al. 2020; Osman et al. 2021). Therefore, the necessary shift for exploring alternative options to overcome the world-scale looming energy crisis, considering the environmental concerns and its mitigation, while confronting the spiralling energy demand has become an urgent need of the hour.

Biomass, unlike other sustainable energy sources such as wind, solar, geothermal, marine and hydropower, can directly produce fuel along with chemicals (Quereshi et al. 2021; Farrell et al. 2019; Farrell et al. 2020). Thus, it is not feasible to substitute fossil-based fuels with the aforementioned sustainable energy sources; hence, biomass 
utilisation to produce fuel and chemicals is required (Bharti et al. 2021). Biomass is classified as non-lignocellulosic or lignocellulosic in nature and exists in various forms such as woody, herbaceous, aquatic debris, farming manure and byproducts and other forms (Osman et al. 2019; Kaloudas et al. 2021). Various technologies are used to convert biomass into fuel or chemicals, such as gasification, combustion, pyrolysis, enzymatic hydrolysis routes and the fermentation processes (Abou Rjeily et al. 2021; Peng et al. 2020).

A recent review discussed integrating hydrothermal and biochemical routes in biomass utilisation from a circular bioeconomy approach (Song et al. 2021). The thermochemical methods usually involve a high energy intake along with solvent or catalyst addition. Meanwhile, the biochemical route has a lengthy cycle period and is less efficient in breaking down recalcitrant biomass materials. Thus, combining those two routes can be promising by incorporating the benefits of both methods in biofuel processing. They proposed a schematic route where hydrothermal routes are being used in the pretreatment stage to prepare the appropriate biomass feedstock for the following biological routes to improve the overall process efficiency and final product yields and vice versa, as shown in Fig. 1. There are unprecedented challenges with the integration of thermochemical and biochemical routes. For instance, the catalysts or solvent utilisation of the thermal routes may result in poisoning or kill the microorganism or generate various inhibitors that can affect the biological progress routes. Furthermore, this integration may lead to additional costs.

Identifying sources of biofuels such as biodiesel and biochar can potentially reduce the environmental impacts of fossil fuels (Balajii and Niju 2019; Gunarathne et al. 2019). Biofuels can also counter the increasing use of fossil resources and prevent pressure on non-renewable sources (Peng et al. 2020; Hassan et al. 2020). However, it is important to use practical, scientific and robust tools to evaluate the real benefits of using biofuels over conventional energy sources (Chamkalani et al. 2020; Kargbo et al. 2021). Life cycle assessment (LCA) has been identified as a comprehensive evaluation approach (Astrup et al. 2015) to measure environmental impacts over the entire production chain of biofuels (Collotta et al. 2019).

Therefore, this review aims to critically evaluate existing biomass to biofuel pathways and associated studies

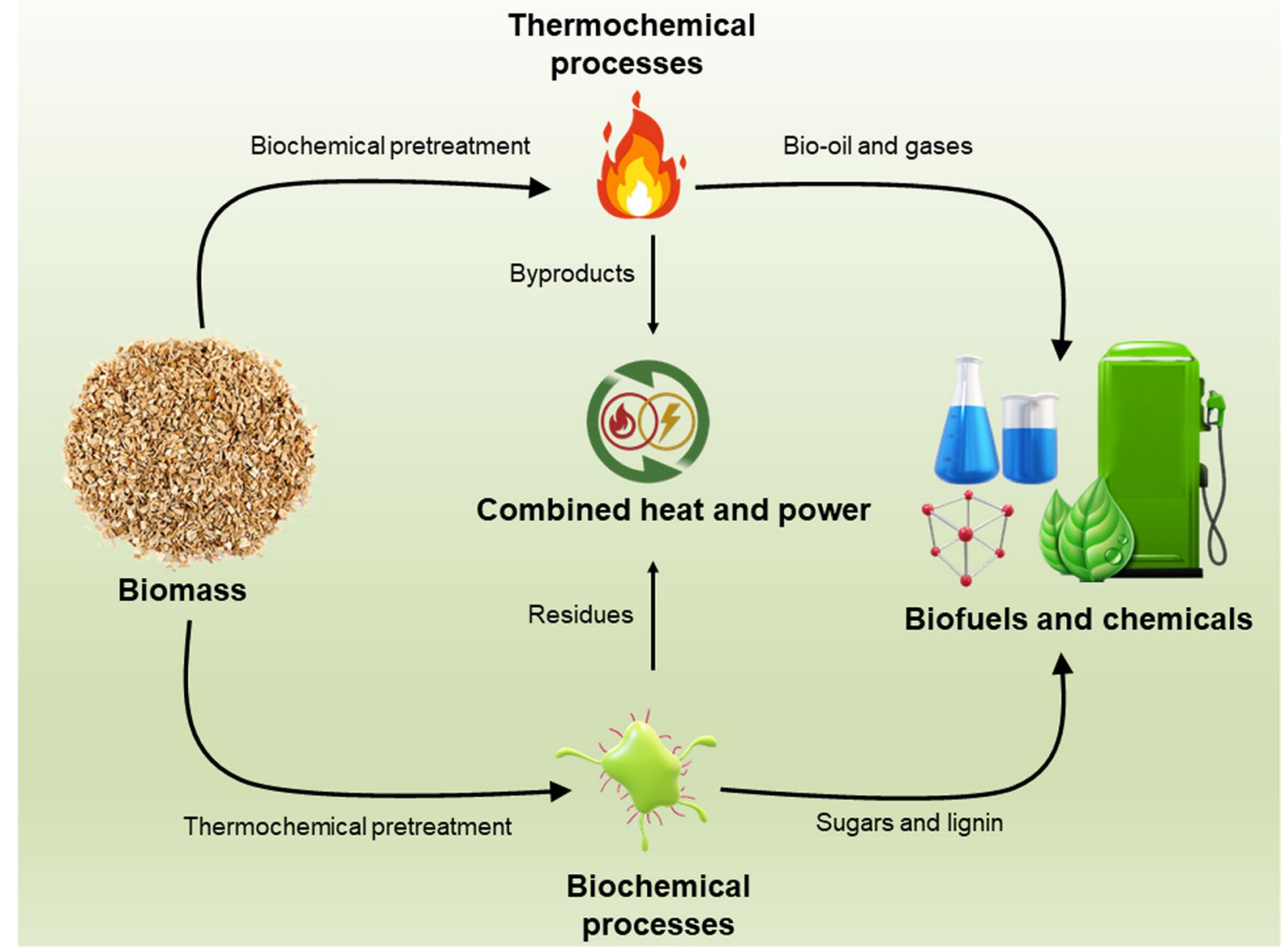

Fig. 1 Integration of hydrothermal and biochemical routes in biomass utilisation from a circular economy approach. Firstly, the biomass is pretreated using a biochemical process for the following thermochem- ical route or vice versa by thermochemical pretreatment for the following biochemical route and eventually producing biofuel or chemicals 
which evaluated environmental impacts for the entire life cycle. The main objectives were to: (1) critically review recent advances in biofuel production processes, (2) analyse existing LCA studies and highlight key methodological approaches and present critical findings.

\section{Bibliometric analysis}

Bibliometric research methodology: TOPIC: 'biomass pyrolysis' OR TOPIC: 'biomass gasification' OR TOPIC: 'biomass combustion' OR TOPIC: 'biomass hydrothermal liquefaction' OR TOPIC: ‘biomass torrefaction' OR TOPIC: 'biomass fermentation' OR TOPIC: 'anaerobic digestion' AND TOPIC: 'biomass into fuels' AND TOPIC: ('thermochemical' OR 'thermo-chemical') AND TOPIC: 'biochemical'. The document type selected in the bibliographic search was articles, the timespan: All years.

It is a complex process to assess the sustainability of biofuels. This is because the use of energy crops can cause the transformation of natural and agricultural land for the cultivation of these crops. Moreover, various technical pathways range from biological to thermochemical conversion processes, all involving range of products and co-products. Therefore, it is imperative to conduct the LCA of the biofuel production chain. This study provides an overview of LCA approaches by recent studies. Keywords: 'biomass', 'biofuel', 'life cycle assessment', 'environmental impact assessment', were used for literature search in the Web of Science database. Forty most complete studies published from 2019-2021 were selected for analysis in the present study.

\section{Biomass conversion technologies}

Harnessing various renewable energy resources is considered affordable, reliable and sustainable solutions for their excessive availability, such as agriculture wastes, domestic wastes, forest residues, industrial wastes and human excreta. Among them, biomass is the most significant contributor with 9\% ( 51 EJ) of the global overall primary energy supply, out of which about $55 \%$ is traditionally used in daily living activities such as heating and cooking, especially in developing countries (Chan et al. 2019). Slade et al. (2014) revealed the possibility of biomass, wastes and energy crops for sharing up to $\sim 100 \mathrm{EJ}$ in the world energy supply (Slade et al. 2014).

Economically, biomass combustion is not the best strategy to utilise biomass because of causing severe environmental damage as well as not recovery of the total energy stored in the substrates (Ullah et al. 2015). In this context, biomass conversion into solid, liquid and gaseous forms is deemed an efficient and green energy supplier for various sectors comprising heat, power and transport fuel (Kargbo et al. 2021; Wang et al. 2020a). For this purpose, two grouped distinct routes, namely thermochemical and biochemical, are currently used. Thermochemical methods use the whole biomass in the presence of a heat source and controllable oxygen atmosphere to modify it to different energy forms.

In contrast, biochemical methods employ enzymes, bacteria or other engineered organisms to transform it to liquid fuels such as drop-in-biofuels (Shen and Yoshikawa 2013; Singh et al. 2016). During the past decades, the biomassderived fuel synthesis process has upgraded from the firstgeneration biofuel to fourth-generation biofuel, passing by second and third generations. Food crops, inedible biomass, macro/microalgal biomass and genetically bioengineered algal and microbial systems-based biofuels are examples for the first, second, third and fourth generations, respectively (Martin 2010; Adelabu et al. 2019; Aro, 2016; Ben-Iwo et al. 2016). Innumerable biomass-based fuels, chemicals and organic compounds such as methane, ethane, propane, butane, ethylene, methanol, ethanol, butanol, dimethyl ether, ammonia, acetic acid, formaldehyde, gasoline, diesel, wax, paraffin, bio-jet fuels and others have been produced throughout different biomass to liquid routes and presently available in the markets throughout the world (Demirbas and Demirbas, 2010).

\section{Thermochemical conversion methods}

Thermochemically, diverse technologies including direct combustion, torrefaction, hydrothermal liquefaction, pyrolysis and gasification have been implemented to produce liquid fuels from biomass, as shown in Fig. 2. Practically, the biomass is decomposed in controllable operational conditions to produce solid, liquid and gas (syngas), which need a supplementary catalytic promotion process to produce liquid fuels called drop-in biofuel. One of its most important features is its capabilities to utilise any biomass type as a biomaterial feedstock, unlike biochemical conversion methods (Raheem et al. 2015).

The thermal-based processes are also classified into lowtemperature, which typically operate at $<300{ }^{\circ} \mathrm{C}$, such as torrefaction, hydrothermal carbonisation and high-temperature that operate at $>300^{\circ} \mathrm{C}$, such as gasification, combustion and pyrolysis biomass conversion methods (Quereshi et al. 2021). The direct combustion (flaming or smouldering) of biomass to produce energy usually operates in the temperature range of $1000-2000{ }^{\circ} \mathrm{C}$ in the presence of air. However, there are emissions associated with such processes as NOx and pollutants (Osman 2020). Hence, gasification which typically operates at $800-1300{ }^{\circ} \mathrm{C}$ is seen as a potential substitute to produce energy and chemicals as well. The synthesis gas produced from the gasification process can 


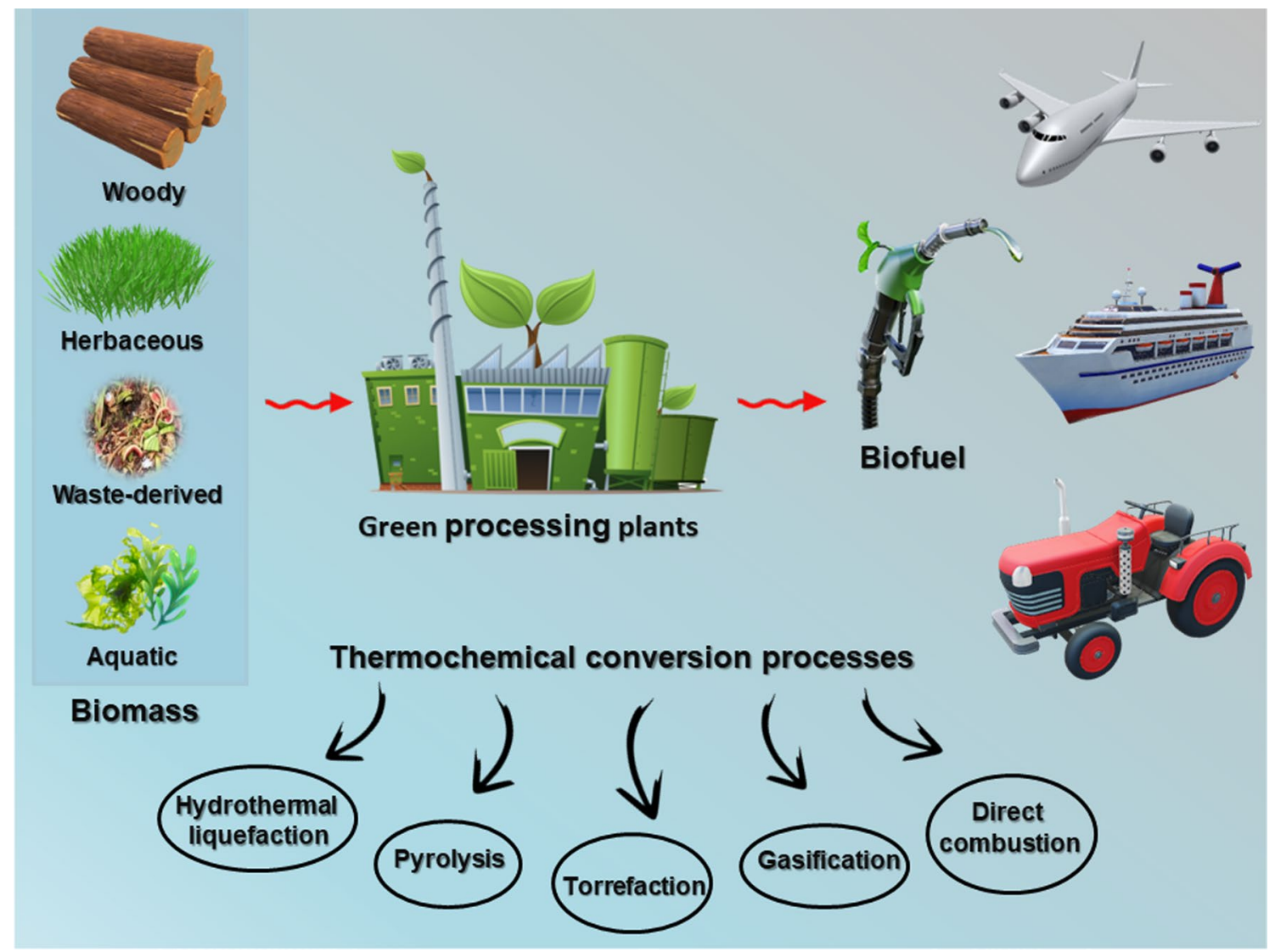

Fig. 2 Thermochemical conversion of biomass, including hydrothermal liquefaction, pyrolysis, torrefaction, gasification and direct combustion processes. Different types of biomass are treated in pro-

be used for electricity production, as well as the conversion into liquid fuel via the Fischer-Tropsch route. Interestingly, pyrolysis is considered a promising route requiring a lower temperature of up to $500{ }^{\circ} \mathrm{C}$ compared to the gasification process.

\section{Direct combustion}

Biomass utilisation as fuel was closely linked with the beginning of human civilisation. Moreover, it is the highest contributor source of clean energy globally (Mladenović et al. 2018). Biomass combustion is described as a group of chemical reactions involving carbon dioxide and water formation resulting from the transformation of carbon and hydrogen, respectively, by oxidation reactions. Improper oxygen quality can result in incomplete combustion associated with release of atmospheric polluters (i.e. $\mathrm{CO}, \mathrm{NO}_{X}$, $\mathrm{SO}_{2}$ and particulate matter) (Yang et al. 2020). Nowadays, the usage of effective fabricated combustion systems such as combustion control systems that simultaneously use conventional and alternative biomass resources has become a predominant feature industrially. cessing plants into liquid biofuels for energy purposes or for the production of value-added chemicals

In waste-to-energy facilities, biomass can be separately burned or combined in co-firing with coal to produce steam, used later in electricity generation. The net electricity efficacy generated from coal/biomass in co-firing power plant system varied from 36 up to $44 \%$ based on as-used strategy and biomass specifications (quantity and quality). Despite the present feasibility of $20 \%$ of co-firing as energy basis in addition to a theoretical achievability of $50 \%$, only less than $5 \%$ and sometimes surpasses to $10 \%$ of biomass contribution continuously. It has been estimated that only $10 \%$ of biomass usage in co-firing systems in power plants can decline the release of $\mathrm{CO}_{2}$ to the atmosphere from 45 to 450 million tonnes/year by 2035 (Sahu et al. 2014). Considering the physicochemical properties of fuel and its required volume to air for avoiding any troubles in the fuel-to-air ratio, excessive air can be forwarded to the reaction to control the temperature of the burning system and ensure complete combustion (Vicente and Alves, 2018). Majorly, combustion physicochemical features of biomass can be categorised into macroscopic and microscopic. Comprehensively, macroscopic features are provided by macroscopic analyses such as proximate analysis such as moisture tenor, sulphur, 
particle magnitude, calorific value, bulk density, fixed carbon and ash fusion. This is coupled with ultimate analysis such as $\mathrm{C}, \mathrm{H}, \mathrm{N}, \mathrm{O}$ and $\mathrm{S} \%$, whereas microscopic analyses include chemical, thermal and mineral data (Khodaei et al. 2015).

Main combustion reactions are as follows: (1) drying out of biomass, (2) pyrolysis, (3) pre-combustion reaction, (4) primary combustion, (5) secondary combustion and (6) effluent stack gas. Parameters that influence the combustion process include biomass magnitude, specific gravity, moisture tenor, ash percentage, elemental composition and anatomical structure as lignin, cellulose and hemicellulose. Different researchers highlighted that about $95-97 \%$ of the global bioenergy production is based on direct biomass combustion (Fouilland et al. 2010; Zhang et al. 2010). Given the massive quantity of ash produced from coal burning $(\sim 780$ million tonnes), a less quantity of biomass ash ( $\sim 480$ million tonnes/year) was assumed to be generated coincided with the burning of 7 billion tonnes of biomass (Vassilev et al. 2013; Izquierdo and Querol, 2012). Retrofitting investment cost characterised to various power plants was USD 430-500/kW, USD 760-900/kW and USD 3000-4000/kW for co-feed plants and separate feed plants indirect co-firing, respectively. These investigated costs were totally more minuscule than the specified outlays of $100 \%$ biomass power generations facilities (Sahu et al. 2014). Table 1 presents the energy content in $\mathrm{MJ} / \mathrm{kg}$ for several kinds of biomass, whereas Table 2 displays the differences in the physicochemical characteristics of biomass and coal-based fuels.
Table 2 Physicochemical characteristics of biomass and coal-based fuels (Demirbas, 2004)

\begin{tabular}{lll}
\hline Property & Biomass & Coal \\
\hline Particle size (mm) & 3 & 100 \\
Fuel density & 500 & 1300 \\
Carbon content* & $43-54$ & $65-85$ \\
Oxygen content* & $35-45$ & $2-15$ \\
Sulphur content* $^{*}$ & Max 0.5 & $0.5-7.5$ \\
$\mathrm{AL}_{2} \mathrm{O}_{3}$ content* & $2.4-9.5$ & $15-25$ \\
$\mathrm{SiO}_{2}$ content* & $23-49$ & $40-60$ \\
$\mathrm{~K}_{2} \mathrm{O}$ content* & $4-48$ & $2-6$ \\
$\mathrm{Fe}_{2} \mathrm{O}_{3}$ content* & $1.5-8.5$ & $8-18$ \\
Ignition temperature & $418-426$ & $490-595$ \\
Heating value & $14-21$ & $23-28$ \\
\hline
\end{tabular}

$*$ (wet $\%$ of dry fuel)

As a solid fuel, fossil-based fuels are still dominating this sector for power generation and heat. However, biomass utilisation in the co-combustion along with fossil-based fuel is seen as a cost-effective and interesting option (Variny et al. 2021). Co-combustion of those two feedstocks offers higher power generation than biomass alone, and biomass ash is acting as a sulphur capture and mitigates the sulphur oxide emissions. On the other hand, some challenges arise when mixing fossil-based coal with biomass, leading to higher corrosion, slagging and fouling due to the high alkali contents within the biomass. In fact, the projected gradual

Table 1 Energy contents of biomass sources, in $\mathrm{MJ} / \mathrm{kg}$

\begin{tabular}{|c|c|c|c|c|c|}
\hline Biomass type & $\begin{array}{l}\text { Energy content } \\
(\mathrm{MJ} / \mathrm{kg})\end{array}$ & Biomass type & $\begin{array}{l}\text { Energy content } \\
(\mathrm{MJ} / \mathrm{kg})\end{array}$ & Biomass type & $\begin{array}{l}\text { Energy content } \\
(\mathrm{MJ} / \mathrm{kg})\end{array}$ \\
\hline Greenwood & 8 & Sour cherry stalk & 17.59 & Coconut shell & 20.00 \\
\hline Manure & 8.650 & Tobacco leaf & 17.97 & Oven dry plant matter & 20 \\
\hline Sewage & 10.510 & Corncob & 17.99 & Wood bark & 20.3 \\
\hline Mustard stalk & 10.73 & Soybean cake & 18.30 & Hazelnut shell & 20.47 \\
\hline Corn stover & 10.730 & Peanut shell & 18.46 & Spruce wood & 20.5 \\
\hline Rice husk & 13.524 & Cereals & 18.61 & Wood bark & 20.57 \\
\hline Peat & 15.30 & Ailanthus wood & 18.93 & Peach stones & 20.657 \\
\hline Cotton gin & 15.500 & Tobacco stalk & 19.02 & Olive cake & 21.57 \\
\hline Olive refuse & 15.77 & Hazelnut seed coat & 19.2 & Olive husk & 21.8 \\
\hline Fuelwood & 16.10 & Eucalyptus (Grandis) & 19.35 & Oak bark & 22 \\
\hline Peach bagasse & 16.24 & Poplar & 19.38 & Olive pits & 22 \\
\hline Potatoes & 17.00 & Colza seed & 19.38 & Apricot stones & 22.082 \\
\hline Potato peel & 17.18 & Spruce wood & 19.45 & Tuncbilek lignite & 23.212 \\
\hline Corncob & 17.3 & Coir pith & 19.50 & Rape seed & 27.80 \\
\hline Sugar beet & 17.40 & Black locust & 19.71 & Tyres & 36.800 \\
\hline Cotton cake & 17.50 & Groundnut shell & 19.80 & Methane gas & 55 \\
\hline
\end{tabular}

Data sourced from: Sami et al. 2001; Demirbas 2001; Demirbas 2005; Atimtay 2010; Haykiri-Acma 2003; Borjesson 1996; Raveendran and Ganesh 1996; Erol et al. 2010; Friedl et al. 2005 
shutdown of fossil-based power plants will limit this cocombustion approach. Technologies such as gasification and pyrolysis should be the main focus, to be competitive and fully available in the near future.

\section{Torrefaction}

Torrefaction is an endothermic pretreatment pathway that mainly proceeded at temperatures ranging from 200 to $300{ }^{\circ} \mathrm{C}$ and a non-accelerated heating rate of less than $50^{\circ} \mathrm{C} /$ $\mathrm{min}$ in an oxygen-free atmosphere. This process is used for upgrading the solid biomass to produce a torrefied product used later as a suitable alternate to coal (Cahyanti et al. 2020). Three transformational reactions, including: volatilisation, polymerisation and carbonisation, occur during the torrefaction process. The process efficacy is influenced by temperature, reaction time, particle magnitude, carrier gas type and flow, catalyst and performance index (Chen et al. 2021). This strategy significantly improves the physicochemical properties of utilised biomass such as hydrophobicity, grindability, mass/energy density, ignitability, moisture expelling and homogeneity (Chen and Kuo 2011).

Commonly, the torrefied product is termed bio-coal or green coal and biochar when used as fuel and soil amendment. Based on the mode of operation, the torrefaction process can be practically classified into dry, wet and steam modes (Barskov et al. 2019). In dry torrefaction, biomaterial feedstock can be torrefied in non-oxidative; for example, nitrogen and carbon dioxide are carrier gases or oxidative mediums such as air, flue gases and other streams with various oxygen concentrations at working temperatures ranging from 200 to $300{ }^{\circ} \mathrm{C}$. Attributing to oxygen presence, the oxidative scenario has a better reaction rate than the other non-oxidative scenario and minimises the reaction time (Thanapal et al. 2014; Lynam et al. 2011).

Contrarily, in the wet torrefaction, the biomass is torrefied in a wet environment, typically water and dilute acids at $180-260^{\circ} \mathrm{C}$ and $5-240 \mathrm{~min}$ for surrounding temperature and holding time, respectively, and the produced solid is termed as hydrochar. Under these subcritical conditions, physicochemical properties of water such as density, diffusivity, dielectric constant and viscosity alter and improve the biomass degradation process, which further upgrades the torrefaction process (Bach and Skreiberg 2016; Balat et al. 2008).

Besides the two mentioned routes, steam torrefaction by introducing steam with elevated temperature and pressure is conducted to torrefy the biomass at $200-260^{\circ} \mathrm{C}$ and 5-10 min for environmental temperature and contact period, respectively. The subsequently accelerated venting of the pressure will allow steam to bulge the biomass and split it with minor loss in the feedstock.
Commercially, the torrefaction process is a potential scenario to be applied in various applications. Salapa et al. revealed the high adsorption capacity of torrefied barley straw of $11.65 \mathrm{mg} / \mathrm{g}$ at operating parameters of $220^{\circ} \mathrm{C}$ and 20 min (Salapa et al. 2018). Other researchers evaluated the torrefaction process's impacts at different contact periods (i.e. 20,40 and $60 \mathrm{~min})$ and temperature $\left(160-260{ }^{\circ} \mathrm{C}\right)$ on ethanol generation based on rice straw. They found out that the best yield of $351 \mathrm{mg} / \mathrm{g}$ was obtained at operating parameters of $220^{\circ} \mathrm{C}$ and $40 \mathrm{~min}$.

Additionally, they confirmed that the torrefied biomass enhanced the yield of ethanol production at a value of $50.67 \%$ compared with the untreated one (Chiaramonti et al. 2011; Sheikh et al. 2013). An enhancement in the ethanol production yield is based on torrefied sugarcane bagasse and waste jute caddies by 19.34 and $20.28 \%$, respectively, compared with the untreated biomass (Chaluvadi et al. 2019).

Igalavithana et al. demonstrated that torrefied product could be positively utilised in soil improvement because it increases air space, water retention efficiency, plant prosperity, microbial community and enzymes activity (Igalavithana et al. 2017). Ogura et al. observed an increase in the growth of the $J$. curcas when it was exposed to varied ratios of $250{ }^{\circ} \mathrm{C}$ torrefied biomass of 1,3 and $5 \%$ (Ogura et al. 2016). The feasibility of using torrefaction condensate in plant safeguarding pathways (pest repellent, insecticide and herbicide) was confirmed considering its minimum amounts of polycyclic aromatic hydrocarbons and phenolic compounds. Comparing the as-generated condensate resulting from different biomass feedstocks such as pine bark, forest residue, wheat straw and willow biomass, the condensate based on willow had the best pesticide performance (Hagner et al. 2020). Table 3 presents more details about the physicochemical properties of numerous biomass after the torrefaction process.

\section{Hydrothermal liquefaction}

Hydrothermal liquefaction is defined as a thermochemical pathway at which the lignocellulosic feedstock, whether wet or dry, is effectively decomposed into renewable liquid fuel (Guo et al. 2015). Based on the mode of operation, it can be divided into two main subclasses: (1) indirect liquefaction and (2) solvent liquefaction (Mika et al. 2018). In the first scenario, biomass or its liquefied products are first converted into syngas followed by a subsequent fuel synthesis (i.e. alcohols and alkanes). In contrast, in the second, direct conversion of biomass into liquid fuel occurs by the action of proton solvents such as water, alcohols, phenols, sulpholane and ionic liquid. Solvent liquefaction has the priority to be implemented over the other scenario because of its remarkable merits, moderate operational conditions and higher yield of products (Gollakota et al. 2018). 
Table 3 Physicochemical properties of biomass after torrefaction

\begin{tabular}{|c|c|c|c|c|c|c|c|}
\hline Biomass & Fixed carbon (wt.\%) & $\begin{array}{l}\text { Volatile matter } \\
\text { (wt.\%) }\end{array}$ & Ash content & $\mathrm{O} / \mathrm{C}$ ratio & $\mathrm{H} / \mathrm{C}$ ratio & $\begin{array}{l}\text { Higher heating } \\
\text { value }(\mathrm{MJ} / \mathrm{kg})\end{array}$ & References \\
\hline Cotton stalk & $16.48-34.01$ & $53.62-75.44$ & $4.79-9.88$ & $0.25-0.83$ & $0.06-0.14$ & $18.68-25.43$ & \multirow{2}{*}{$\begin{array}{l}\text { Chen et al. (2014a), } \\
\text { Chen et al. } \\
\text { (2014b), Chen } \\
\text { et al. (2014c) }\end{array}$} \\
\hline Corn stalk & $18.41-41.19$ & $35.30-69.32$ & $9.18-20.52$ & $0.18-0.85$ & $0.06-0.15$ & $18.26-23.61$ & \\
\hline Rice straw & $17-48$ & $44.5-79.6$ & $6-8$ & $0.24-0.81$ & $0.09-0.16$ & $19.0-28.6$ & $\begin{array}{l}\text { Nam and Capareda } \\
\text { (2015) }\end{array}$ \\
\hline Oil palm fibre & $5-25$ & $3-48$ & $6-7$ & $0.22-0.62$ & $0.02-0.10$ & $11.13-23.98$ & \multirow[t]{4}{*}{ Chen et al. (2013) } \\
\hline $\begin{array}{l}\text { Cryptomeria } \\
\text { japonica }\end{array}$ & $12-25$ & $5-54$ & 0 & $0.23-0.63$ & $0.02-0.09$ & $21.94-28.81$ & \\
\hline Coconut fibre & $2-27$ & $2-40$ & $0.5-3$ & $0.22-0.55$ & $0.02-0.09$ & $11.86-26.46$ & \\
\hline Eucalyptus & $15-28$ & $10-61$ & 0 & $0.28-0.64$ & $0.02-0.09$ & $20.59-26.28$ & \\
\hline Bamboo & $25.05-47.03$ & $48.05-70.20$ & $1.43-1.95$ & $0.34-0.63$ & $0.07-0.10$ & $21.02-27.26$ & \multirow{3}{*}{$\begin{array}{l}\text { Chen et al. (2012a), } \\
\text { Chen et al. } \\
(2012 b)\end{array}$} \\
\hline $\begin{array}{l}\text { Rice husk sugar cane } \\
\text { bagasse Madagas- } \\
\text { car almond }\end{array}$ & $22.27-41.17$ & $33.33-61.88$ & $13.18-23.11$ & $0.32-0.70$ & $0.06-0.10$ & $17.68-21.48$ & \\
\hline Oil palm & $32.58-43.67$ & $39.60-53.76$ & $9.97-13.52$ & $0.29-0.54$ & $0.06-0.08$ & $20.61-23.54$ & \\
\hline Reed canary grass & $13.3-21.3$ & $70.5-80.3$ & $6.4-8.3$ & $0.67-0.74$ & $0.11-0.13$ & $20.0-21.8$ & \multirow{2}{*}{$\begin{array}{l}\text { Bridgeman et al. } \\
\text { (2008) }\end{array}$} \\
\hline Wheat straw & $15.6-38$ & $51.8-77$ & $7.4-10.2$ & $0.48-0.72$ & $0.10-0.12$ & $19.8-22.6$ & \\
\hline Olive tree pruning & 20.4 & 74.5 & 2.4 & 0.89 & 0.16 & N/A & $\begin{array}{l}\text { Martin-Lara et al. } \\
\text { (2017) }\end{array}$ \\
\hline Olive trimmings & $16.54-32.57$ & $55.96-77.65$ & $3.87-7.87$ & $0.18-0.70$ & $0.08-0.12$ & $19.6-28.4$ & \multirow{4}{*}{$\begin{array}{l}\text { Martin-Lara et al. } \\
\text { (2017), Volpe } \\
\text { et al. (2015) }\end{array}$} \\
\hline Olive pulp & $19.98-50.40$ & $41.99-77.22$ & $1.50-6.67$ & $0.24-0.72$ & $0.08-0.12$ & $20-26.8$ & \\
\hline Orange peel waste & $38.9-62.2$ & $37.8-61.1$ & $3.3-5.6$ & $0.24-0.65$ & $0.06-0.10$ & $21.45-28.74$ & \\
\hline Lemon peel waste & $35.7-61.8$ & $38.2-64.3$ & $3.5-6.3$ & $0.22-0.68$ & $0.06-0.10$ & $21.09-28.75$ & \\
\hline $\begin{array}{l}\text { Jatropha seed } \\
\text { residue }\end{array}$ & $13.5-35.5$ & $55.5-79.8$ & $6.25-7.60$ & $0.29-0.49$ & $1.14-1.50$ & $21.8-23.8$ & Hsu et al. (2018) \\
\hline
\end{tabular}

The main process parameters that directly influence the hydrothermal liquefaction process include biomass composition, particle size, pressure, temperature, heating rate, residence time, feed/solvent ratio and presence of the catalyst and reducing gas. Generally, the hydrothermal liquefaction process operates at mild operational parameters of temperature in the temperature range of $250-500{ }^{\circ} \mathrm{C}$ and pressure of 5-35 MPa and contact periods of 5-60 min. These processes are conducted in the presence of solvents such as sub/supercritical water, organic solvents and mixed solvents such as the combination of water + organic solvent (Yang et al. 2019; Akalin et al. 2017).

The utilisation of water as a solvent has numerous advantages over conventional organic solvents due to its natural occurrence in biomass and eco-friendliness. On the contrary of water state at ambient conditions, the compressed water in a liquid state at the following critical conditions of temperature and pressure of $374{ }^{\circ} \mathrm{C}$ and 22.064 $\mathrm{MPa}$, respectively, generates higher ionic products (i.e. $\mathrm{H}_{3} \mathrm{O}^{+}$and $\mathrm{OH}^{-}$) ions. Proximity to the mentioned critical conditions, the physicochemical properties of water such as density, viscosity, dielectric constant, polarity and permittivity change (Arun et al. 2021). Decrease in the viscosity as well as dielectric constant and weakening of water hydrogen bonds consequently enhance the solubility of hydrophobic organic compounds associated with an improvement in the catalytic activity of acid-base reactions. This results in biomass conversion into four main fractions: bio-crude fuel (liquid), water-soluble products, solid residue and gases.

Moreover, hydrothermal liquefaction is regarded as lesser energy consumption and a higher efficiency strategy than pyrolysis because of the better physicochemical properties. The produced bio-crude from the hydrothermal liquefaction process has an oxygen content of 10-20 wt.\% and a heating value of 30-35 MJ/kg, which is typically higher than those obtained from the conventional pyrolysis process (Guo et al. 2019). During the hydrothermal liquefaction process, the oxygen contained in the biomass is partially eliminated by dehydration, decarboxylation and decarbonylation reactions associated with producing $\mathrm{CO}, \mathrm{CO}_{2}$ and $\mathrm{H}_{2} \mathrm{O}$. Despite its higher quality, the higher oxygen content produces a highly sticky and acidic bio-crude product with a low heating value. Distinctly, its quality enormously varies depending on the operational parameters and biomaterial feedstock composition (Scarsella et al. 2020). 
Hence, the importance of downstream upgrading treatment such as catalytic cracking and hydrotreating for the obtained bio-crude cannot be ignored for further utilisation as a transportation drop-in fuel. In situ upgrading using various acidic or alkaline homogenous catalysts such as $\mathrm{HCl}$, $\mathrm{H}_{3} \mathrm{PO}_{4}, \mathrm{~K}_{2} \mathrm{CO}_{3}, \mathrm{Na}_{2} \mathrm{CO}_{3}, \mathrm{NaOH}, \mathrm{KOH}$ and $\mathrm{Ca}(\mathrm{OH})_{2}$ and heterogeneous catalysts has been studied in detail (Perkins et al. 2019). Despite its cost and energy-saving nature, it has some disadvantages, such as operating at high pressure that results in the necessity of (1) solid/water slurries reliable pumping, (2) suitable unit metallurgy to avoid the potentially corrosive nature of slurries at the operational parameters of elevated pressures and mild temperatures and (3) usage of heat exchangers with high surface areas to overcome the problem of low heat transfer coefficients (Beims et al. 2020). Li et al. (2017) liquefied wheat straw biomass at a pre-adjusted temperature of $270{ }^{\circ} \mathrm{C}$ for $120 \mathrm{~min}$, and the resulting oil was forwarded for manufacturing of bio-polyols and polyurethane foams (Li et al. 2017).

Crude oil originated from liquefaction of bark biomass was directed to produce bio-based phenol-formaldehyde formable resole as reported by Li et al. (Li et al. 2016). Spent coffee grounds of approximately 15 and $17.4 \%$ for lipids and proteins, respectively, were liquefied to output crude bio-oil under $\mathrm{N}_{2}$ atmosphere at $\left(200-300{ }^{\circ} \mathrm{C}\right)$ and $(5-25 \mathrm{~min})$. The highest yield of acetone-recovered bio-crude oil (47.3 wt\%) was obtained at $275^{\circ} \mathrm{C}$ and 10 min with an estimated higher heating value of $31.0 \mathrm{MJ} / \mathrm{kg}^{-1}$, better than that of spent coffee grounds of $20.2 \mathrm{MJ} / \mathrm{kg}$ (Yang et al. 2016). Xiu et al. performed a study on swine manure composed of $<1 \%, 17.1 \%$, $22.3 \%$ and $\sim 35 \%$ for lignin, crude protein, ash content and saccharide, respectively. They successfully liquefied into bio-crude oil under $\mathrm{N}_{2}$ atmosphere at a temperature range of $260-340{ }^{\circ} \mathrm{C}$ and a contact period of $15 \mathrm{~min}$ with a yield of $24.2 \mathrm{wt} . \%$ and higher heating value of $36.05 \mathrm{MJ} / \mathrm{kg}$ (Xiu et al. 2010). Table 4 presents the proximate as well as ultimate investigations of crude bio-oil prepared from several biomaterials through the hydrothermal liquefaction process.

\section{Pyrolysis}

Pyrolysis is counted as one of the most as-used thermochemical scenarios to degrade the carbonaceous biomass, such as cellulose, hemicellulose and lignin (Aravind et al.

Table 4 Proximate and ultimate analyses of bio-crude oil prepared from several biomass through hydrothermal liquefaction process. Where, the higher heating value is abbreviated as $\mathrm{HHV}$

\begin{tabular}{|c|c|c|c|c|c|c|c|c|c|c|}
\hline \multirow[t]{2}{*}{ Feedstock } & \multicolumn{5}{|c|}{$\begin{array}{l}\text { Elemental composition of product spe- } \\
\text { cies after Hydrothermal liquefaction }\end{array}$} & \multicolumn{4}{|c|}{$\begin{array}{l}\text { Physicochemical properties of the prod- } \\
\text { ucts }\end{array}$} & \multirow[t]{2}{*}{ References } \\
\hline & $\mathrm{C}(\%)$ & $\mathrm{H}(\%)$ & $\mathrm{N}(\%)$ & $\mathrm{O}(\%)$ & $\mathrm{S}(\%)$ & Ash \% & Moisture \% & HHV & Yield \% & \\
\hline Spirulina algae & 68.9 & 8.9 & 6.5 & 14.9 & 0.86 & - & - & 33.2 & 32.6 & Vardon et al. (2011 \\
\hline Anaerobic sludge & 66.6 & 9.2 & 4.3 & 18.9 & 0.97 & - & - & 32.0 & 9.4 & \\
\hline Cladophora glomerata & 26.8 & 3.53 & 2.14 & 20.48 & 0.22 & 36.5 & 9.1 & 10.29 & - & Plis et al. (2015) \\
\hline Nannochloropsis gaditana & 40.3 & 5.97 & 6.30 & 14.49 & 0.37 & 28.3 & 4.1 & 18.53 & - & \\
\hline Almeriansis & 73.2 & 9.3 & 5.1 & 0.8 & 11.7 & 35.8 & 20.0 & - & 42.6 & López Barreiro et al. (2015) \\
\hline Gaditana & 74.2 & 9.3 & 4.0 & 0.6 & 11.8 & 36.2 & 12.4 & - & 50.8 & \\
\hline Swine manure & 71 & 8.9 & 4.1 & 0.21 & 14.2 & 35 & - & - & 61 & Toor et al. (2011) \\
\hline Algae Dunaliella tertiolecta & 63.55 & 7.66 & 3.71 & - & 25.8 & 30.7 & - & - & 25.8 & \\
\hline Porphyridium & $66-83$ & $5-11$ & $0-12$ & $0-1$ & $8-27$ & $22.8-36.9$ & - & - & $5-25$ & \\
\hline A.esculenta & 73.8 & 8 & 3.8 & 14 & 0.8 & - & - & 33.8 & 17.8 & Anastasakis and Ross (2015) \\
\hline L.digitata & 70.5 & 7.8 & 4.0 & 17 & 0.7 & - & - & 32 & 17.6 & \\
\hline L.Saccharina & 31.3 & 3.7 & 2.4 & 26.3 & 0.7 & 24.2 & 9.2 & 12 & - & \\
\hline Fucus vesiculosus & 32.88 & 4.77 & 2.53 & 35.63 & 2.44 & 11.8 & - & 15.0 & - & Ross et al. (2008) \\
\hline Laminaria hyperborea & 34.97 & 5.31 & 1.12 & 35.09 & 2.06 & 11.2 & - & 16.54 & - & \\
\hline Miscanthus & 46.32 & 5.58 & 0.56 & 41.79 & 0.2 & 2.1 & - & 19.08 & - & \\
\hline A.azuera & 40.82 & 5.56 & 0.63 & 52.99 & - & 10.61 & 6.03 & 52.99 & - & Aysu et al. (2016) \\
\hline Nannochloropsis Oceana & 77.6 & 4.9 & 3.4 & - & 0.3 & - & - & 37.70 & 54.2 & Caporgno et al. (2016) \\
\hline Aspen wood & 75.2 & 8.2 & 0.5 & 15.8 & 0.3 & 0.48 & 3.8 & 34.3 & - & Pedersen et al. (2016) \\
\hline Arthrospira platensis & 74.5 & 10.2 & 6.8 & 7.5 & 1.0 & - & - & 38.65 & 30 & Lavanya et al. (2016) \\
\hline Tetraselmis & 71.4 & 9.5 & 5.7 & 12.3 & 1.1 & - & - & 35.58 & 29 & \\
\hline Nannochloropsis Salina & 55.16 & 6.87 & 2.73 & 33.97 & 1.27 & 2.48 & 4.95 & 25.40 & - & Toor et al. (2013) \\
\hline Seaweed meal & 43.99 & 5.95 & 5.21 & 36.13 & 1.02 & 7.7 & 7.92 & 18.35 & - & Ferrera-Lorenzo et al. (2014) \\
\hline Laurel algae & 48.97 & 6.38 & 3.02 & 41.63 & - & 10.53 & 9.95 & 19.77 & - & Ertas and Alma (2010) \\
\hline
\end{tabular}


2020). This results in the generation of solid, liquid and gas biofuels in an oxygen-free atmosphere via endothermic reaction (Perkins et al. 2018). The yield of the pyrolytic products is influenced by factors, including feedstock composition such as structure and complexity. This is also coupled with pyrolysis impacting factors such as particle size, temperature, heating rate, residence time, inert gas type, inert gas flow, catalyst type and others (Azizi et al. 2018).

Complex reactions such as dehydration, decarboxylation, decarbonylation, hydrogenation, isomerisation, aromatisation, depolymerisation and charring are involved in the thermal decomposition process of biomass. Typically, pyrolysis of biomass undergoes the following steps: (1) transfer of heat from its source to biomass to initiate the reaction, (2) elevated pyrolysis temperature of primary vapours contributes to volatiles and char formation, (3) because of the influx of hot vapours to the biomass, heat migration continues between unpyrolysed fuel and hot volatiles, (4) volatiles condensation associated with secondary reactions leads to tar formation and (5) autocatalytic secondary pyrolysis reactions take place in conjugation with primary pyrolytic reaction (Dabros et al. 2018).

The impact of different pyrolysis operational parameters occurs at different stages such as dehydration, decomposition and reforming. With elevated heating rate, minimum vapour contact periods and a surrounding temperature of $500{ }^{\circ} \mathrm{C}$, liquid yields can be maximised (Chintala, 2018). These conditions directly prohibit (1) thermal or catalytic cracking of the primary decomposition products due to char presence to lesser non-condensable gas molecules as well as (2) their polymerisation to char (Kasmuri et al. 2017). Table 5 presents different working modes of the pyrolysis process. Other pyrolysis types such as catalytic and assisted microwave, carbon dioxide, additives, solar and hydro-pyrolysis can be performed to upgrade the product's yields.

Slow pyrolysis is a process in which organic materials are slowly heated at a low heating rate between 5 and $50{ }^{\circ} \mathrm{C}$ min- 1 and the longest residence time above $10 \mathrm{~s}$ in the absence of oxygen, typically producing about $80 \%$ of carbon as the main product (Antoniou and Zabaniotou, 2013). Fast pyrolysis is a strategy by which organic materials are quickly heated at faster heating rates of $>103{ }^{\circ} \mathrm{C} \mathrm{s}^{-1}$ and shorter contact periods of up to $3 \mathrm{~s}$ without air existence.
The primary product is liquid oil (Bridgwater, 2012a). Ultrafast or flash pyrolysis is a highly accelerated pyrolysis at a high heating rate with major gas and oil products. The operating conditions are as follows temperature (medium-high $\left(700-1000{ }^{\circ} \mathrm{C}\right)$, shortest residence time and fastest heating rate. Yields of outputs are: (1) liquid condensate $(10-20 \%)$, (2) gases $(60-80 \%)$ and (3) char $(10-15 \%)$ (Priharto et al. 2020).

Catalytic pyrolysis is a process in which catalysts such as natural zeolite, $\mathrm{Cu} / \mathrm{Al}_{2} \mathrm{O}_{3}, \mathrm{Co} / \mathrm{Mo} / \mathrm{Z}$, Zeolite- $\mathrm{B}, \mathrm{Fe}_{2} \mathrm{O}_{3}$ and $\mathrm{Ni}-\mathrm{CaO}-\mathrm{C}$ are used to decrease the reaction operating temperature and increase the selectivity towards desired products. This process is used to optimise the biomass conversion into liquid fuels with improved physicochemical properties (Cai et al. 2019; Chai et al. 2020). Catalytic co-pyrolysis of biomass and plastic waste showed promising results in upgrading the oil quality by removing oxygen from the biomass and producing more aromatics and olefins (Wang et al. 2020b). This is due to the high hydrogen and carbon contents within the plastic waste and consequently acting as a hydrogen donor in the catalytic co-pyrolysis process and thus eliminates the oxygenated compounds. This approach is seen as a sustainable, efficient and economical approach to upgrading the bio-oil quality, along with extending the catalyst's lifetime.

Microwave-assisted pyrolysis is a new thermochemical process that transforms biomaterial feedstock into liquid oil using microwave input heat energy. In contrast to the conventional process, microwave-assisted pyrolysis is a more effective and controllable technique. $\mathrm{CO}_{2}$-assisted pyrolysis is a process by which $\mathrm{CO}_{2}$ is delivered as a reactive medium instead of inert $\mathrm{N}_{2}$ in utilising the pyrolysis process and enhancing the syngas yield and declines the produced oil but also decreases the greenhouse gas emissions (Kwon et al. 2019).

Additive-assisted pyrolysis is a type of pyrolysis at which metal salts such as sodium, potassium and calcium salts and inorganic additives (zeolites, biochar) are added and thus having some advantages over conventional pyrolysis. It has a great potential to decrease the required operating temperature, cracking time and solid residue yield, in addition, to increase the cracking efficacy of wastes and improves the quality of pyrolysis products (Wang et al. 2019a).
Table 5 Different working modes of the pyrolysis process (Bulushev and Ross, 2011)

\begin{tabular}{llllll}
\hline Mode of action & $\begin{array}{l}\text { Working tem- } \\
\text { perature }\left({ }^{\circ} \mathrm{C}\right)\end{array}$ & Residence time (seconds) & \multicolumn{2}{l}{ Yields (wt. \%) } & Gas \\
\cline { 4 - 6 } & & & Char & Liquid & 35 \\
Slow & 450 & Very long $(>30)$ & 35 & $30(70 \%$ water $)$ & 35 \\
Medium & 500 & Moderate $(10-30)$ & 25 & $50(50 \%$ water $)$ & 25 \\
Fast & 500 & Short $(<2)$ & 13 & $70(30 \%$ water $)$ & 12 \\
Flash & 500 & Very short $(<0.5)$ & $<13$ & 75 & $<12$ \\
Gasification & $>800$ & Long & 10 & 5 & 85 \\
\hline
\end{tabular}


Solar pyrolysis is a process in which solar renewable energy can be introduced as thermal input sources rather than electrical energy that maximise biofuel production and reduce $\mathrm{CO}_{2}$ emissions. Hydropyrolysis is a particular type of pyrolysis at which biomaterial feedstock is decomposed with the assistance of high pressurised hydrogen. Using the mentioned technique above, a higher yield of hydrocarbons with improved structures can be attained (Marcilla et al. 2013).

Pyrolysis products can be categorised as solid, liquid and gases that can be exploited to generate chemicals, energy, electricity and transportation fuels. Proximate and ultimate analyses are beneficial to characterise the obtained products. Char, pyrolytic char or biochar, is the produced solid, chemically not pure carbon, and contains carbon as the main constituent, hydrogen, nitrogen, ash and some volatiles. The highly porous char is used in several applications as adsorbent and soil amendment for wastewater treatment and enhancement of crop yields. Bio-oil (tar) is a dark brown, sticky liquid produced from the thermal degradation of biomass. Typically, it consists of more than 400 chemical compounds (i.e. aldehydes, alcohols, amines, acids, esters, ethers, ketones, phenol derivatives, ketones, guaiacols, furans, oligomers, syringols and sugars) (Henrich et al. 2016). Considering its low carbon, nitrogen and sulphur content, $\mathrm{CO}, \mathrm{SO}_{X}$ and $\mathrm{NO} x$ emissions are low, hence preparing bio-oil and conventional fuels.

Table 6 displays a comparison between the properties of prepared bio-oil (after water removal) and conventional liquid fuels. Concurrently, Table 7 shows physiochemical properties of as-formed bio-oil resulting from the pyrolysis of several biomaterials feedstocks without applying any upgrading strategy as well as comparing it with other conventional fuels, respectively. Both condensable and non-condensable gases are generated throughout the first

Table 6 Comparison of bio-oil properties with conventional fuels (Bridgwater, 2012b)

\begin{tabular}{lllll}
\hline Property & Bio-oil & Diesel & Heating oil & Gasoline \\
\hline pH & $2.0-3.0$ & - & - & - \\
Viscosity at $40{ }^{\circ} \mathrm{C}(\mathrm{cP})$ & $40-100$ & 2.4 & $1.8-3.4$ & $0.37-0.44$ \\
Density at $15^{\circ} \mathrm{C}\left(\mathrm{kg} / \mathrm{m}^{3}\right)$ & 1200 & $820-950$ & 865 & 737 \\
Heating value $(\mathrm{MJ} / \mathrm{kg})$ & $18-20$ & 42 & 45.5 & 44 \\
Pour point $\left({ }^{\circ} \mathrm{C}\right)$ & -15 & -29 & -6 & -60 \\
Flash point $\left({ }^{\circ} \mathrm{C}\right)$ & $48-55$ & 42 & 38 & 40 \\
Solids $(\mathrm{wt} \%)$ & $0.2-1.0$ & - & - & - \\
Ash & $<0.02$ & & $<0.01$ & \\
Carbon & $42-47$ & 87.4 & 86.4 & 84.9 \\
Hydrogen & $6-8$ & 12.1 & 12.7 & 14.76 \\
Oxygen & $46-51$ & - & 0.04 & - \\
Nitrogen & $<0.1$ & $392 \mathrm{ppm}$ & 0.006 & 0.08 \\
Sulphur & $<0.02$ & 1.39 & $0.2-0.7$ & - \\
\hline
\end{tabular}

decomposition stage and secondary cracking of vapours. Bio-oil is formed by subjecting the heavier molecules condensable gases to subsequent cooling and condensation processes, while the lower molecules non-condensable gases (i.e. $\mathrm{CO}$ and $\mathrm{CO}_{2}$ ) are not condensed during the cooling stage.

\section{Gasification}

Gasification is a process by which carbonaceous materials are thermochemically converted into valuable gases, commonly referred to as synthesis gases in the presence of a gasifying agent such as air, oxygen, steam, $\mathrm{CO}_{2}$ or a combination of them at a temperature above $700{ }^{\circ} \mathrm{C}$. Primarily, the produced gas consists of $\mathrm{CO}, \mathrm{H}_{2}, \mathrm{CO}_{2}$ and $\mathrm{CH}_{4}$ (Shahabuddin et al. 2020). Generally, the gasification process comprises four main steps: (1) heating or drying $\left(100-200{ }^{\circ} \mathrm{C}\right)$ to decrease its moisture content, (2) pyrolysis, (3) oxidation or partial combustion and (4) gasification. Firstly, the moisture content $(30-60 \%)$ of the biomass is vaporised at about $200{ }^{\circ} \mathrm{C}$. Then, pyrolysis includes the decomposition of different biomass, including cellulose, hemicellulose and lignin, into solid residues and volatiles occurs (Thomson et al. 2020). Oxidation or partial combustion is the third stage in which the resultant volatiles and char residues are oxidised to $\mathrm{CO}, \mathrm{CO}_{2}$ and $\mathrm{H}_{2} \mathrm{O}$ with gasifying agent assistance beyond $700{ }^{\circ} \mathrm{C}$ (exothermic reaction).

By the action of $\mathrm{CO}_{2}$ or steam as gasifying agents, carbon and volatile compounds react with them in terms of reduction reaction to produce syngas at a temperature over $800^{\circ} \mathrm{C}$ in an endothermic reaction (Situmorang et al. 2020; Hanchate et al. 2021). Briefly, simultaneous exothermic and endothermic reactions are included in the gasification process, and the first previously mentioned reactions are considered as heat suppliers for the endothermic one. Main reactions involved in the gasification include carbon reaction such as primary or secondary steam reforming, hydrogasification, oxidation, shift reaction, mechanisation and steam reaction.

The efficiency of the gasification process is impacted by different operational parameters such as feedstock composition, moisture content, ash content, granulometry, pressure, temperature, gasifier's type, gasifying agents, equivalence ratio and steam to biomass ratio (Díaz González and Pacheco Sandoval 2020). Basically, the gasifier's selection: fixed or moving bed (dry ash/slagging), fluidised bed (circulating, bubbling) and entrained flow (upflow, downflow), is controlled by several factors, for instance, feedstock composition, gasifying agent and product requirements (Mehrpooya et al. 2018). Syngas chemical composition and its heating values vary based on the as-used gasification method, as presented in Table 8 . 


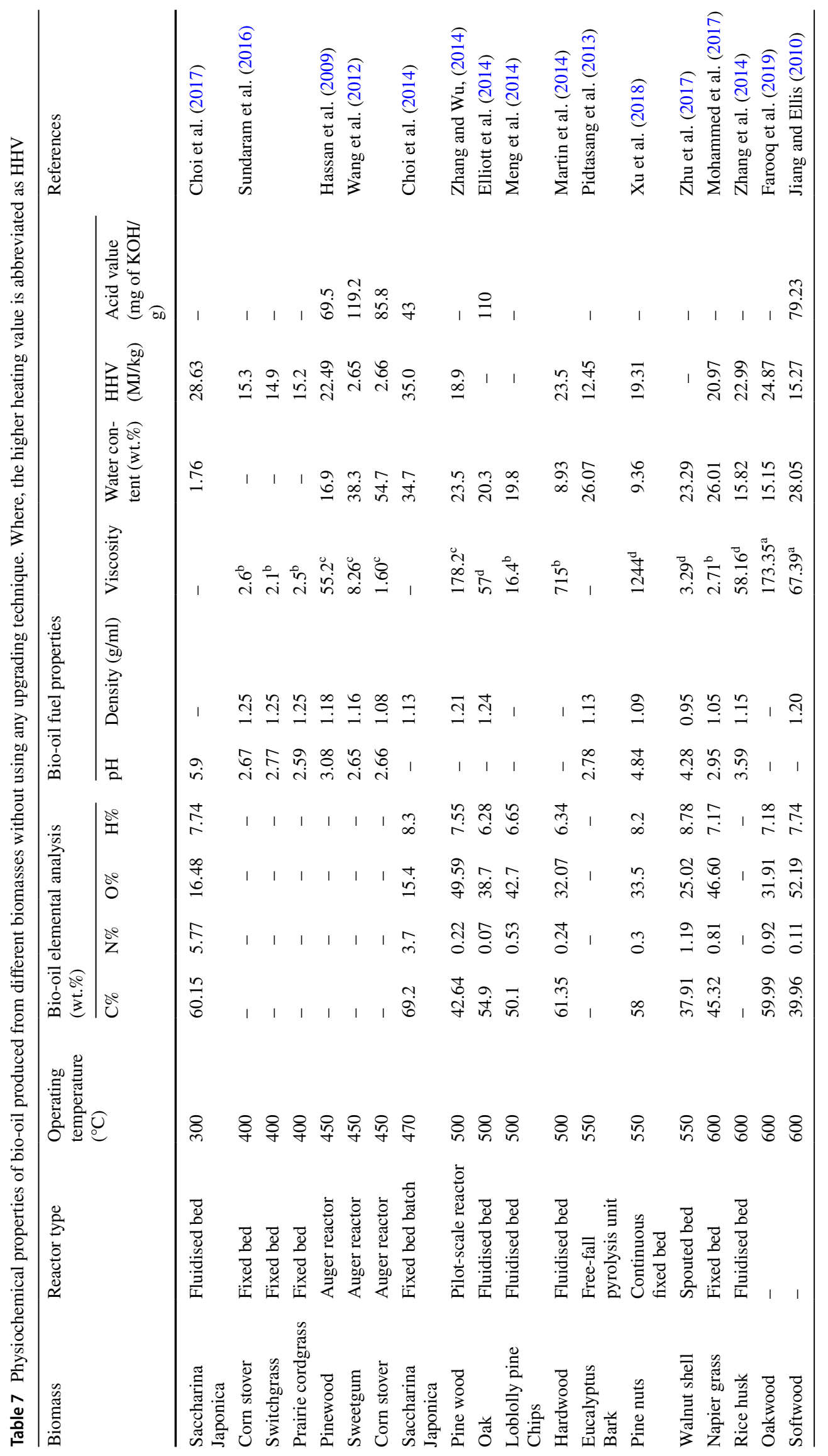




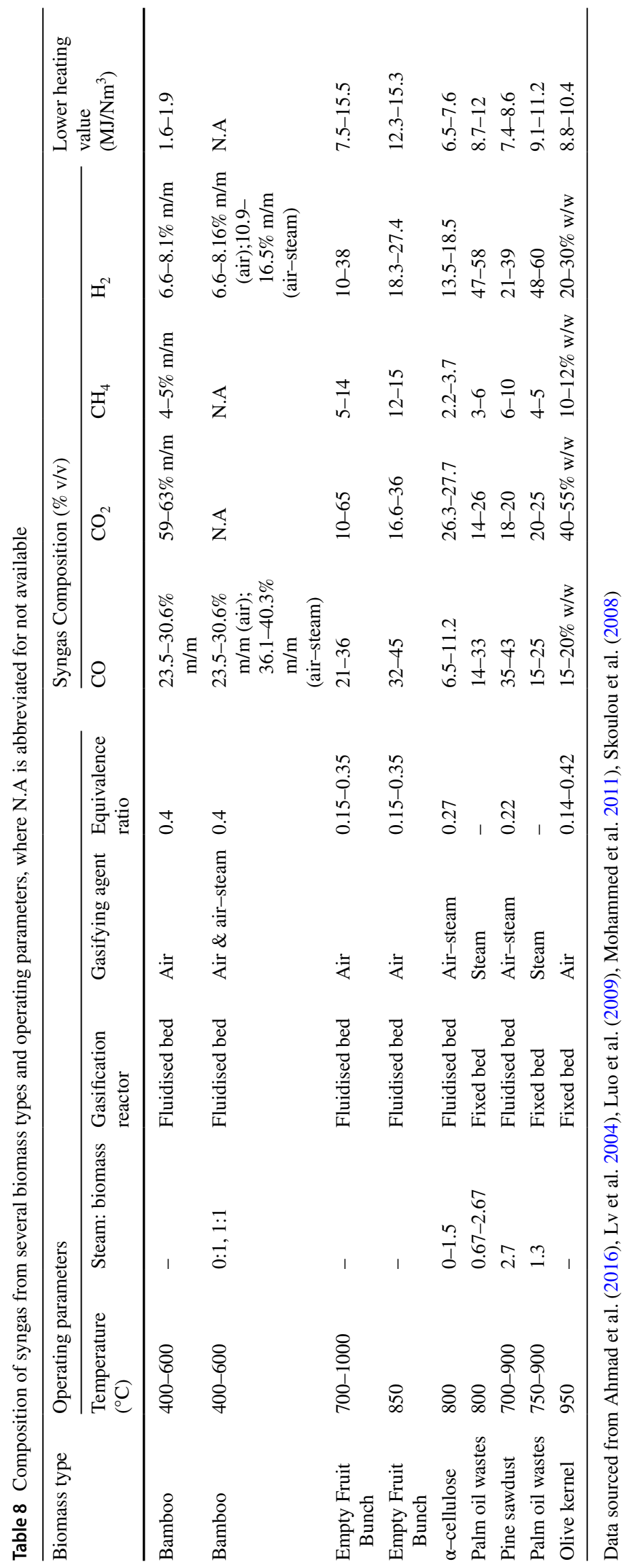


Other gasification types such as plasma, supercritical and microwave have been operated to improve gasification yields. In plasma gasification, an intense plasma thermal process is used to catalyse and ionise the organic compounds in biomass and gas, respectively, into syngas with slag using a plasma torch powered by an electric arc (over $2500{ }^{\circ} \mathrm{C}$ ). Supercritical water gasification is a type of gasification typically performed in the presence of a vast amount of water for the generation of $\mathrm{H}_{2}$ and $\mathrm{CH}_{4}$ (Rodriguez Correa and Kruse, 2018). The process yield is very high, mainly affected by different parameters such as temperature, catalyst and biomass/water ratio.

Microwave gasification is a compelling scenario for transforming biomass. This technique's benefits over the traditional methods include uniform distribution of temperature, efficacy for large particle handling and higher heating values (Chen et al. 2015). Different technologies such as scrubbers (i.e. spray, dynamic wet, cyclonic, impactor, venture and electrostatic) and filters (fabric bag, fibrous ceramic, metallic foam and granular bed) have been used to clean up the syngas from different contaminants and hence improve its quality for numerous applications. A list of global biofuel-based facilities comprising its manufacturer, country, starting-up year, feedstock composition, downstream products and asused technology is shown in Table 9.

\section{Biochemical conversion methods}

Biochemical conversion pathways such as anaerobic digestion and fermentation can be employed to generate various biofuels from waste biomass, as shown in Fig. 3. Biochemical conversion methods have numerous merits, including high product selectivity, high product yield and flexibility to be operated at ambient temperature and pressure conditions (Singh et al. 2016). Ethanol and bio-hydrogen can be produced from the fermentable biomass via alcoholic fermentation and dark fermentation/photo-biological routes, respectively, whereas biogas can be produced anaerobic digestion as follows (Osman et al. 2020).

\section{Fermentation}

Fermentation is a process by which biological activities are utilised conjugated with air existence known as aerobic fermentation or without air called anaerobic fermentation (Karimi et al. 2021). Bioconversion of biomass to biofuel comprises of sequential stages: pretreatment, hydrolysis (acid/enzymatic) and fermentation (Alvira et al. 2010).

The pretreatment step aims to damage the cell wall as well as exhibit cellulose and hemicellulose for subsequent hydrolysis. It can be classified into four main categories, including: (1) physical, e.g. grinding, (2) physicochemical, e.g. wet oxidation, (3) chemical, e.g. oxidising agents and organic solvents, and (4) biological or combination of them (Haghighi Mood et al. 2013). Secondly, pretreated biomass is decomposed into monomers by the action of acid/enzymatic hydrolysis. Lastly, the intermediate monomers are converted into alcohols using yeast/bacteria (Liu et al. 2015).

Based on the consolidation degree of the mentioned stages, ethanol production can be configured into four routes: (1) separate hydrolysis and fermentation, (2) simultaneous saccharification and fermentation, (3) simultaneous saccharification and co-fermentation and (4) consolidated bioprocessing. In separate hydrolysis and fermentation scenarios, enzyme generation, hydrolysis, hexose and pentose fermentation are employed in separate OR individual reactors. Despite execution of hydrolysis in addition to fermentation at their optimised conditions, accumulation of cellobiose and glucose enzymes during hydrolysis process negatively prohibits the efficiencies of cellulases (Margeot et al. 2009).

In the simultaneous saccharification and fermentation scenario, cellulose hydrolysis and hexose fermentation simultaneously run at the same reactor that overcomes cellulase inhibition because of instant consumption of sugars by fermenting microorganisms (Hahn-Hägerdal et al. 2007). In the simultaneous saccharification and cofermentation scenario, two genetically modified strains of Saccharomyces cerevisiae and Zymomonas mobilis are used to co-ferment glucose and xylose in the same reactor. In the consolidated bioprocessing scenario, only one microorganism is simultaneously utilised for hydrolysis and fermentation, which decreases the operation cost and enhances the process efficacy (Lin and Tanaka, 2006).

Different modes of fermentation can be briefly viewed as follows: photo-fermentation is a fermentative transformation of organic substrate to produce bio-hydrogen driven by miscellaneous groups of photosynthetic bacteria. This is occurring throughout a set of biochemical reactions in three steps like anaerobic conversion. The difference between photo-fermentation and dark fermentation is its proceeding in the presence and absence of light, respectively.

Alcoholic fermentation is another type of fermentation driven by yeast by which sugars are transformed into cellular energy associated with the generation of ethanol and carbon dioxide. Considering its occurrence in the absence of oxygen, it can be categorised as an anaerobic integration process. Heterotrophic algae or yeast can transform sugars into lipids inwards their cells associated with using suitable solvents to break down the cells (Eukajtis et al. 2018). The resultant lipids can be further purified and improved to liquid forms of transport fuels by hydro-treated vegetable oil diesel scenario, whereas genetically modified bacteria consume sugars and consequently produce short-chain gaseous 


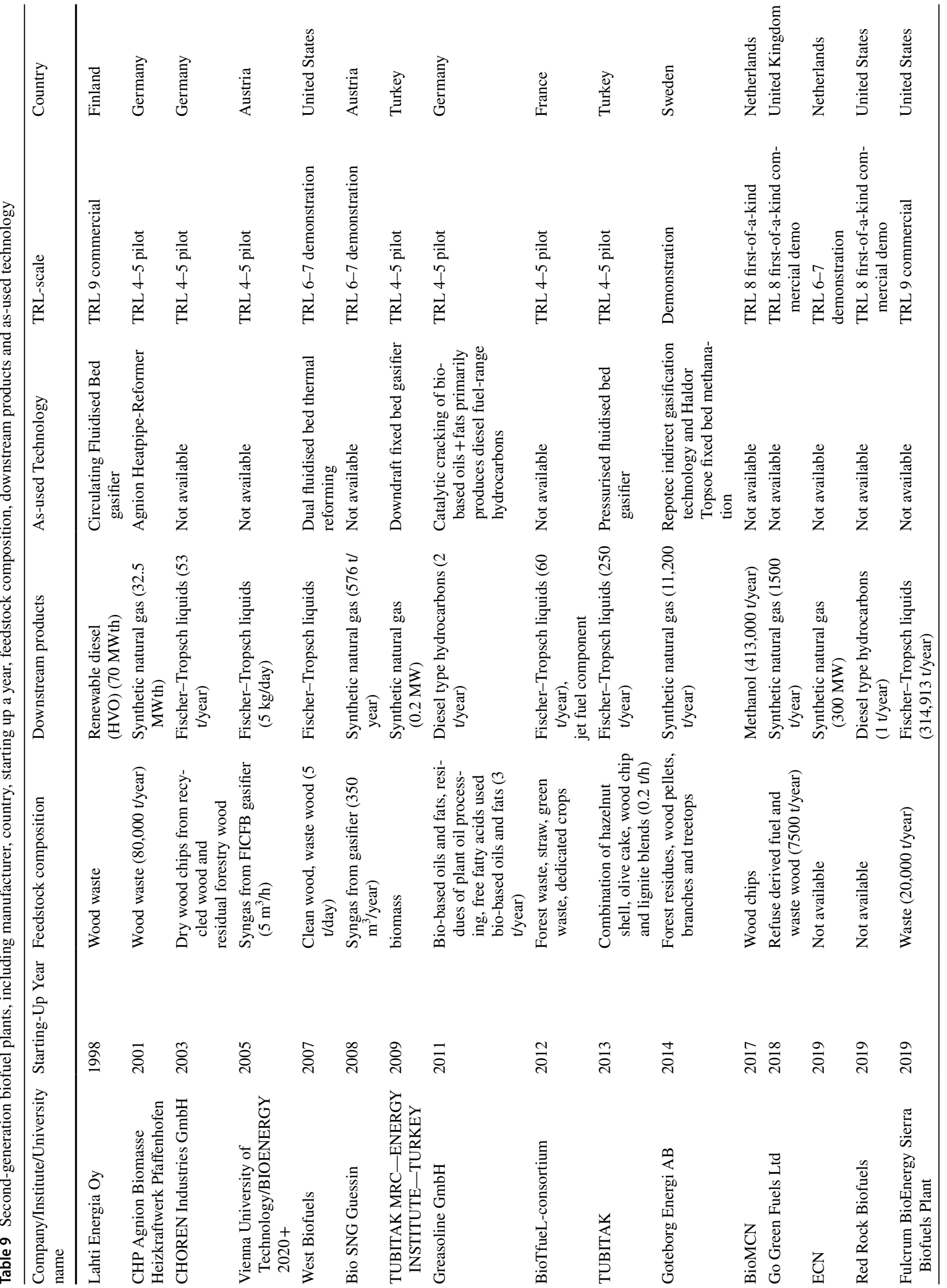


alkenes that can be transformed by oligomerisation and hydro-treatment into jet/gasoline.

Electro-fermentation is a novel fermentation pathway by which microorganisms can be induced by using an electric field that can positively: (1) stabilise and optimise metabolisms of fermentation integration process by regulating redox and $\mathrm{pH}$ imbalances, (2) stimulate whether breakdown or elongation of carbon chain via different oxidative/reduction conditions, (3) enhance the synthesis of adenosine triphosphate and upgrade the yield of microbial biomass, (4) extract purposed products via selective membranes and (5) the possibility of directing the fermentation reaction towards the manufacture of a single and specific product (Schievano et al. 2016).

\section{Anaerobic digestion}

Anaerobic digestion is a biochemical, cost-effective and environmentally sustainable approach for upcycling biomass (Al-Wahaibi et al. 2020). It is a recovery process by which biodegradable organic substrates' bioconversion into renewable biogas occurs by several anaerobic organisms in an oxygen-free environment (Kainthola et al. 2019). Typically, the produced biogas comprises $50-75 \%$ of $\mathrm{CH}_{4}, 30-50 \%$ of $\mathrm{CO}_{2},\left(0-3 \%\right.$ of $\mathrm{N}_{2}, \sim 6 \%$ of $\mathrm{H}_{2} \mathrm{O}$ and $0-1 \%$ of $\mathrm{O}_{2}$. The biogas could also contain other minor impurities such as ammonia, hydrogen, hydrogen sulphide, nitrogen and water vapours (Wainaina et al. 2020).

The growth rate of biogas production was $11.2 \%$, with approximately 58.7 billion $\mathrm{Nm}^{3}$ in 2017 . It has been investigated that the production outlay of biogas resulting from anaerobic digestion plants will be declined by about $38 \%$ in 2050 compared with 2015. Collectively, more than 17,240 operating anaerobic digestion facilities in Europe generated 63.3 TWh of electricity based on biogas, which represented about 14.6 million European households of the global consumption rate per year in 2014. The American Biogas Council announced that about 2,000 anaerobic digestion plants were operated to handle the residues from municipal wastewater treatment facilities, food waste and animal manure digestion in 2015 (Shrestha et al. 2017).

In addition to biogas energy generation, the anaerobic digestion process contributes to nutrient recovery, mitigation of greenhouse gas emissions as well as depletion of dissolved oxygen (Bharti et al. 2021). Several parameters, including alkalinity, organic loading rate, temperature, $\mathrm{pH}$, feedstock composition, hydraulic retention time and concentration of volatile fatty acids, directly affect the anaerobic digestion process and the physiochemical properties of biogas (i.e. composition and heating value). Considering the organic substrates, the anaerobic digestion process can be categorised into wet, semi-dry and dry due to varying $\%$ of total solids (Feng and Lin 2017). 


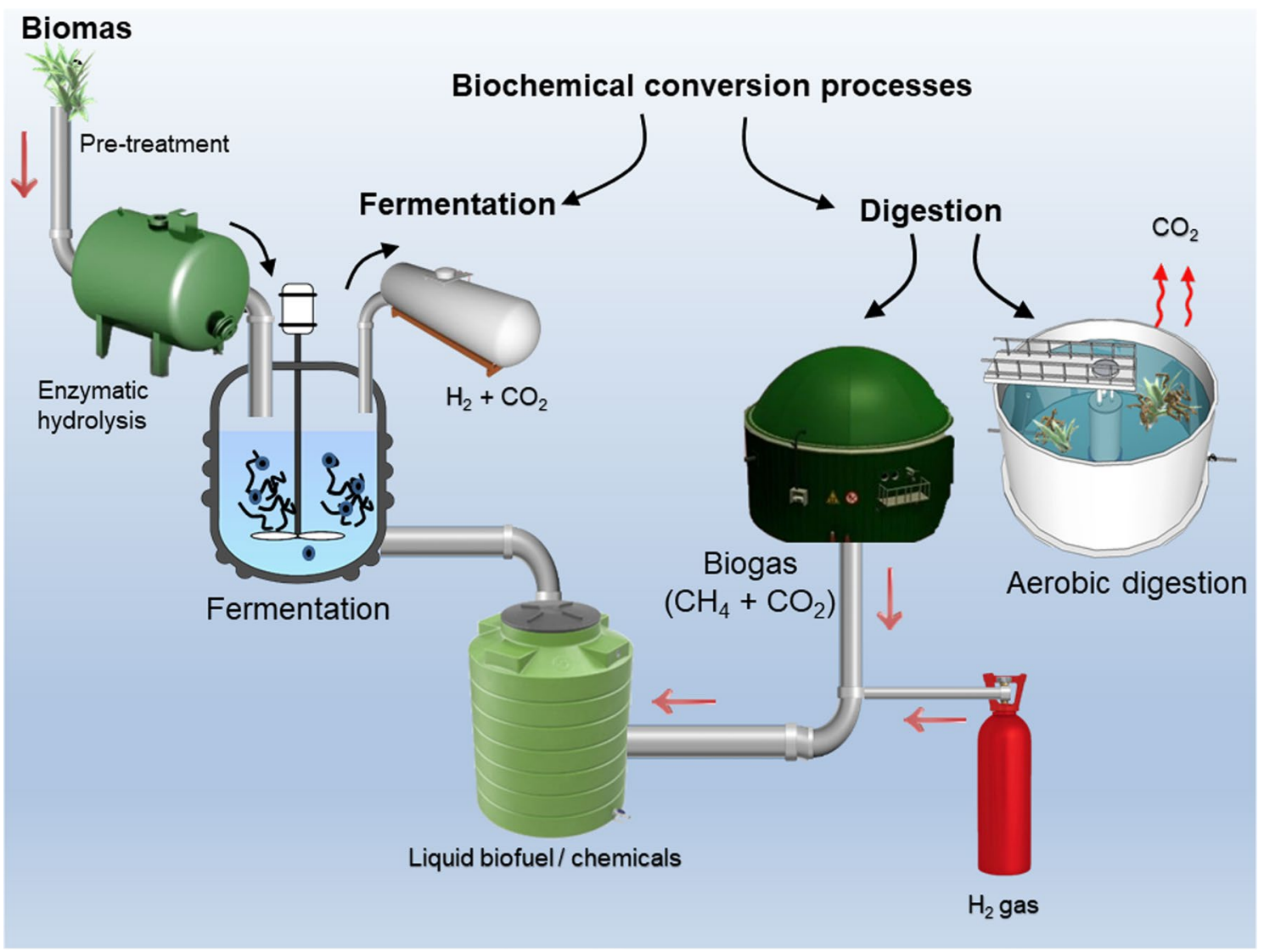

Fig. 3 Biochemical conversion route of biomass utilisation into biofuel, including fermentation and anaerobic digestion processes. Two types of digestion: aerobic digestion, which produces carbon dioxide and fertiliser, while anaerobic digestion produces biogas which in

Commonly, an anaerobic digestion scenario comprises four consecutive steps, including hydrolysis, acidogenesis, acetogenesis and methanogenesis, catalysed by different microorganisms, whereas hydrolysis is deemed as the ratedetermining step.

Hydrolysis is the first stage of anaerobic digestion at which complex biopolymers (i.e. carbohydrates, lipids, proteins, polysaccharide and nucleic acid) are converted into simple soluble compounds (i.e. amino acid, fatty acids, monomers, sugar, purines and pyrimidine) by the action of enzymes (i.e. amylases, lipases and proteases) produced from hydrolytic bacteria (Sawatdeenarunat et al. 2015).

Secondly, acidogenesis is the second stage of anaerobic digestion at which the simplified amino acids, sugar, fatty acids and monomers are converted into intermediate biomolecules (i.e. alcohols, volatile fatty acids, propionic and butyric acids) by fermentative bacteria.

Acetogenesis is the third step at which the mentioned acidogenesis products serve as a substrate to produce acetate by homoacetogens bacteria. Methanogenesis is the last step at which both acetate and carbon dioxide are directed to turn, along with hydrogen, could be converted into liquid fuel. The other route is the fermentation process, where the biomass is firstly pretreated and then followed by enzymatic hydrolysis and fermentation, and finally, the production of liquid biofuel

produce methane (biogas) by two sets of methanogens: acetoclastic and hydrogen utilising organisms (Matheri et al. 2018; Ganesh Saratale et al. 2018). The first group (acetoclastic methanogens) convert acetate into methane and carbon dioxide, while the other ones (hydrogen-utilising methanogens) generate methane by applying hydrogen and carbon dioxide as electrons donor and acceptor, respectively.

Several enhancement techniques as pretreatment steps such as: (1) physical, e.g. milling, (2) chemical, e.g. ionic liquid and surfactant, thermophysical, e.g. microwave irradiation, (3) thermochemical, e.g. supercritical $\mathrm{CO}_{2}$, ammonia fibre explosion and ammonia fibre percolation, and (4) biological (microbial and enzymatic) can precede to enhance anaerobic digestion process (Gautam et al. 2020). To upgrade the quality of biogas (impurities removing), an additional cleaning step can be added to capture $\mathrm{CO}_{2}$, $\mathrm{H}_{2} \mathrm{~S}$ and water vapours and avoid mechanical and chemical appliances throughout its utilisation. Different materials (i.e. silica gel) can be used to tackle $\mathrm{H}_{2} \mathrm{~S}$ and water vapours.

In contrast, other techniques (i.e. water scrubbing, organic scrubbing, membrane separation, cryogenic technology and 
pressure swing adsorption) can be delivered to sequester $\mathrm{CO}_{2}$ from the product and subsequently elevate its calorific value (Nag et al. 2019). The raw biogas can be used for producing electrical energy, whereas the improved biogas can be directly inserted into the natural gas grid or utilised as fuels for vehicles. From the economic point of view, two substrates can be simultaneously mixed (anaerobic codigestion) to overcome the disadvantages of mono-digestion and enhances its feasibility. Numerous types of reactors, including submerged packed beds, fluidised beds and other types, have been employed for the anaerobic digestion treatment process of wastewater with high biochemical oxygen demand (Paudel et al. 2017).

\section{Production of liquid biofuel such as methanol and bio-oil from biomass}

Historically, more than a hundred years ago, Giacomo Ciamician mentioned in his manuscript entitled 'Photochemistry of the Future' about the urgent need for the sustainable transfer from non-renewable to renewable sources (Sharma et al. 2020; Qasim et al. 2020). In 2017, the global energy consumption was rated at 13.5 billion tons of oil ( $\sim 656$ exajoules) by a yearly growth rate of $1.7 \%$. Relatedly, an increase in the uncontrolled population has directly deepened the negative effects of the ascending pressure on non-renewable resources globally (Pradhan et al. 2018). Considering the new United Nations reports, it has been stated that with an introduction of approximately 83 million people to our globe per year, the current global population of 7.6 billion is anticipated to increase to 8.6, 9.8, and 11.2 billion by 2030, 2050 and 2100, respectively. Based on the United States Energy Administration (EIA) estimations, the global energy requirement is increasing annually and projected to rise by almost $28 \%$ in 2040 ( 739 quadrillions Btus) (Sharma et al. 2020). Majorly, high pressure on energy consumption originates from countries with robust economic growth. A total enhancement in energy consumption has been investigated by non-OECD (Organisation for Economic Co-operation and Development) countries ( 473 quadrillions Btus) by 2040, compared with its counterpart of Organisation of the Petroleum Exporting Countries ( 266 quadrillions Btus) (Kumar et al. 2020).

The main route of biomass into liquid fuel 'drop-in' is through the gasification process. On a small scale, woody biomass gasification outperforms combustion and pyrolysis in terms of technological and economic impacts, while pyrolysis has been identified as the best large-scale method for upgrading woody biomass (Solarte-Toro et al. 2021). The biomass into liquid fuel such as bio-methanol starts with biomass gasification under low pressure using downdraft gasifier owing to its low tar formation along with long residence time ( $\mathrm{Li}$ et al. 2021). Where steam and oxygen (95\% vol.) are commonly the gasification agents, the heat required for the gasification is supplied by biochar combustion. The gasification gas usually has a low content of light hydrocarbon and high-water content; thus, an in situ reformer with steam is used to convert them into carbon monoxide and hydrogen, followed by cooling of the hightemperature reformer effluent gas before subjecting it to gas composition adjustment (compression and sulphur removal steps). This is then followed by the water gas shift reaction process, where steam is introduced into the unit to increase the hydrogen to carbon monoxide ratio to 2 , and then, carbon dioxide is removed before the methanol synthesis stage. Finally, the compressed synthesis gas is pre-heated before entering the methanol reactor, where carbon monoxide hydrogenation produces bio-methanol.

Interestingly, bio-methanol derived from biomass feedstocks can be used to produce light olefins of 230 million tonnes demand worldwide (Li et al. 2021). Ethylene, propylene and butylene as light olefins are commercially produced from petroleum-based hydrocarbon via steam cracking, where currently, biomass into olefins route gains interest through bio-methanol, dimethyl ether or Fischer-Tropsch process.

Bio-methanol can produce biodiesel via the transesterification process, where triglycerides/ lipids are transformed into fatty acid methyl ester using a catalyst and alcohol, mainly methanol (Al-Mawali et al. 2021; Al-Muhtaseb et al. 2021; Hazrat et al. 2021). There is also a non-catalytic route for microalgal biodiesel production via subcritical and supercritical methanol (Karpagam et al. 2021).

As a type of biomass, algae recently showed some merits in producing biofuels, such as high lipid productivity, carbon dioxide capture, high growth rate, limited land requirement and high production yields (Sekar et al. 2021; Peter et al. 2021). Then again, there are still challenges, such as the post-processing of algae and the cultivation process. Besides the biofuels mentioned earlier, microalgae can produce biooil via different processes, most commonly pyrolysis and others such as gasification and liquefaction as thermochemical routes. Pyrolysis is preferred herein due to its simplicity, speed, better yields, along with operating conditions.

Bio-oil is the main pyrolytic product in fast and flash pyrolysis, along with biochar and gaseous products (Xiao et al. 2021). However, when applying bio-oil directly in petroleum (gasoline and diesel), engines will not produce sufficient heat due to its low calorific value, a high number of oxygenated compounds ( $>300)$ and high water content (20-40 wt.\%), which is negligible in hydrocarbon fuels (gasoline and diesel) (Gupta et al. 2021). Furthermore, due to its high viscosity and the presence of acidic compounds, it will provide a flow barrier when it passes into injectors and engines, resulting in engine corrosion. Besides, crude 
bio-oil will generate coking complications in the combustion stage due to the presence of a high number of solid particles. Therefore, upgrading the bio-oil via the integrated refinery is crucial for its commercialisation and producing value-added chemicals, char utilisation and gasoline grade fuel. The bio-oil upgrading process starts with moisture separation either by distillation (fractional or azeotropic), using catalysts, additional pyrolysis or biomass pretreatment techniques (demineralisation and torrefaction). This is followed by value-added chemicals extraction from the aqueous phase (acids, ketones, alcohols, ethers and esters) to improve the overall economics of the process. Some chemicals could also be extracted from the organic phase. The final organic residue of the bio-oil is then upgraded into a transportation fuel via various techniques such as deoxygenation, emulsification, hydrocracking, esterification, catalytic cracking and heavy fuel blending.

However, there are challenges associated with the upgrading routes for bio-oil, mentioned above, as they are still not commercialised due to the high cost of the catalyst, short catalyst life and complex operating conditions (high-pressure, special reactor requirements). Furthermore, extracting the chemicals in their low concentration is expensive and will require more investigation on the low-cost solvent, catalyst and process optimisation, primarily as the physicochemical characteristics of the bio-oil rely on the catalyst used. The catalyst minimises the heteroatom content of the biooil and increases the hydrogen-to-carbon ratio (H/C). This consequently lowers the harmful emissions of $\mathrm{NO}_{X}, \mathrm{SO}_{X}$ and increases the calorific value of the bio-oil (Nagappan et al. 2021). Selling the biochar produced during pyrolysis can also increase the overall economics, which can be used in the carbon sequestration, adsorption of the contaminants, soil amendments and catalytic supports in bio-oil upgrading that enhances the circular bioeconomy of the process (Fawzy et al. 2021).

\section{Life cycle assessment of biomass to biofuel conversion processes}

Life cycle assessment is recognised as an effective framework for assessing impacts on natural environment, humans and natural resources for processes, products and systems. It provides evidence-based data to policymakers to make long-term strategic decisions and improve environmental sustainability. The four main stages defined by ISO 14,040 and IS0 14,044 for conducting LCA are: (1) goal and scope definition, (2) life cycle inventory analysis, (3) environmental impacts assessment and (4) life cycle interpretation (Lewandowski et al. 2000).

Herein, we analysed 40 LCA studies published from 2019 to 2021 on biofuels (Table 10). These studies covered a wide range of biomass feedstocks, geographical span, biofuels produced, life cycle tools and inventories used. Even if the geographical span or biomass feedstock considered was similar, no two studies were identified as identical to each other. This demonstrates that LCA practitioners and decision-makers would need to identify the routes towards environmental sustainability and energy efficiency while paying heed to the specific processes modelled in the studies.

\section{Goal and scope definition}

Goal and scope definition includes defining specific purpose, aim and objectives for conducting LCA. This stage is imperative to understand overall results and LCA findings. It incorporates defining functional unit and respective system boundaries. Functional units are quantified description of the performance requirements that the product system fulfils and are linked with functions of the product rather than with physical products. It was observed that about $32 \%$ of the reviewed studies used 'units of bioenergy in J or kWh' as the functional unit, while about $22 \%$ recorded LCA results for 'amount of biofuels produced' such as in kg (Fig. 4).

The system boundaries included in the LCA studies control what processes will be considered for computing environmental impacts. Figure 5 shows the generalised three crucial phases for biofuel production: (1) Phase 1 includes biomass cultivation, fertiliser application, impacts of fertiliser on soil, carbon emissions from land use, use of marginal and/or forest land, transportation of produced biomass to the production system, (2) Phase 2 incorporates chemical, thermal, biochemical, thermochemical processes for conversion of biomass to biofuels and related environmental impacts due to chemicals, electricity and energy procurement, upgradation of biofuels for final purpose, and (3) Phase 3 involves environmental impacts due to co-products management and emissions due to biofuel use.

The system boundaries included in the LCA studies varied for processes and systems considered. It was observed that about $90 \%$ of the reviewed studies considered Phase 1 , Phase 2 , while only $25 \%$ of the studies included Phase 3 (Fig. 6). This highlights a paucity of research in the biofuel LCA field containing a holistic approach and includes all the phases of the biofuel production chain. Even where the studies focused on Phase 3, they primarily dealt with anaerobic digestion. Most of the studies focused on specific processes of the biofuel production chain, focusing on critical areas of concern rather than evaluating the overall impacts of the entire production chain. Interestingly, use of biofuels has increasingly been recognised as a measure to reduce greenhouse gas emissions; however, very few studies addressed the use phase of biofuels and compared them to conventional sources. 


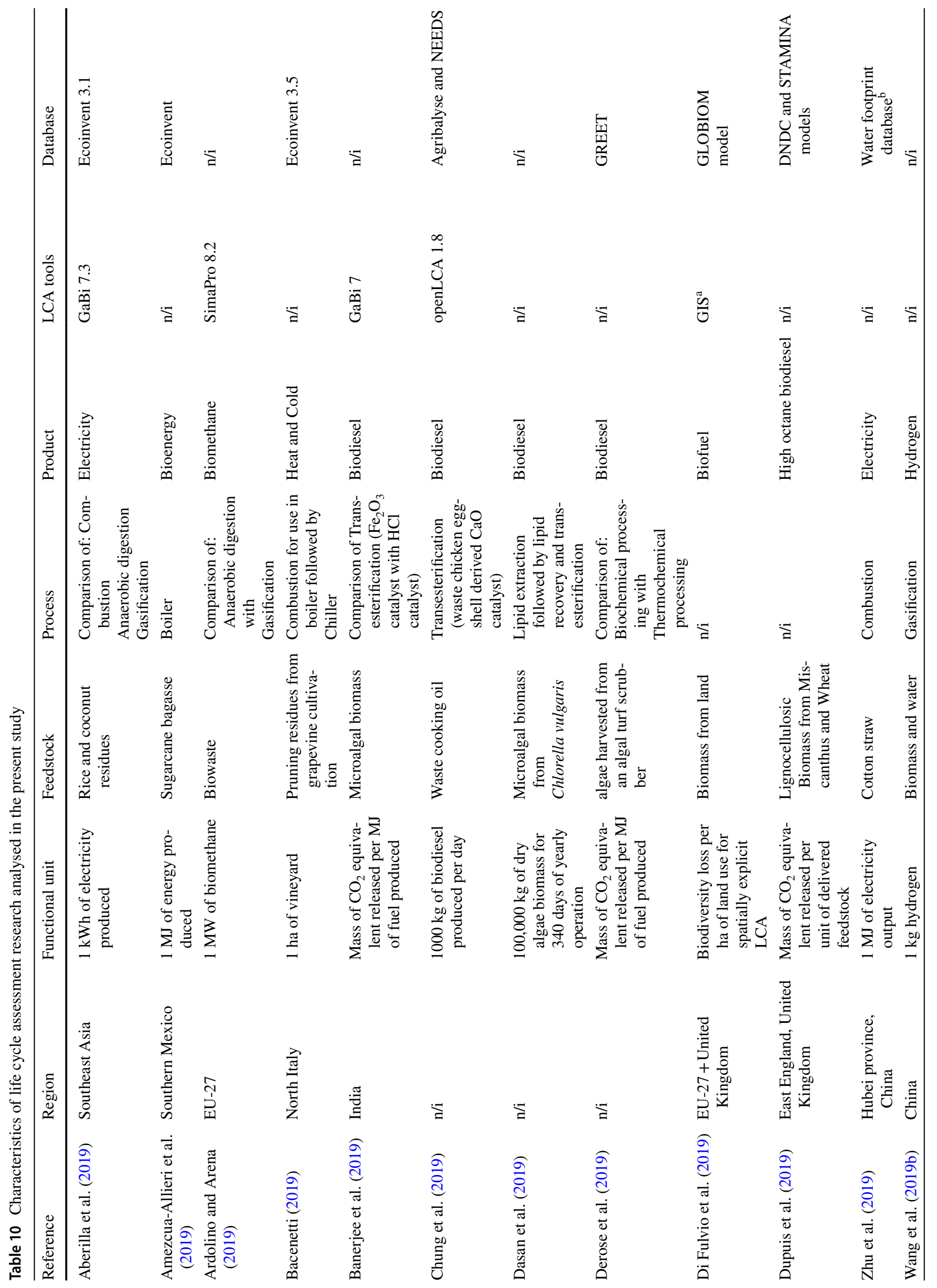




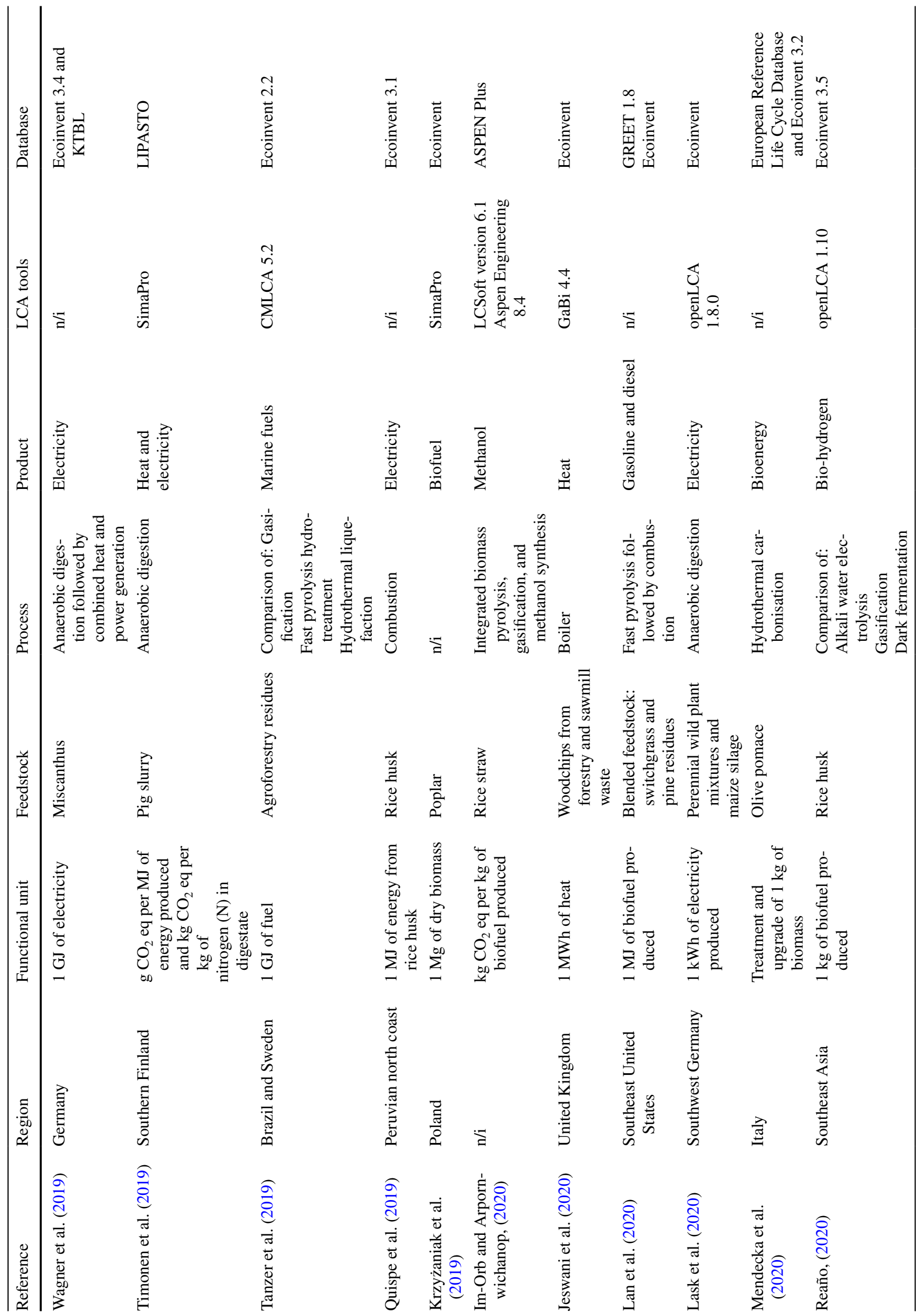




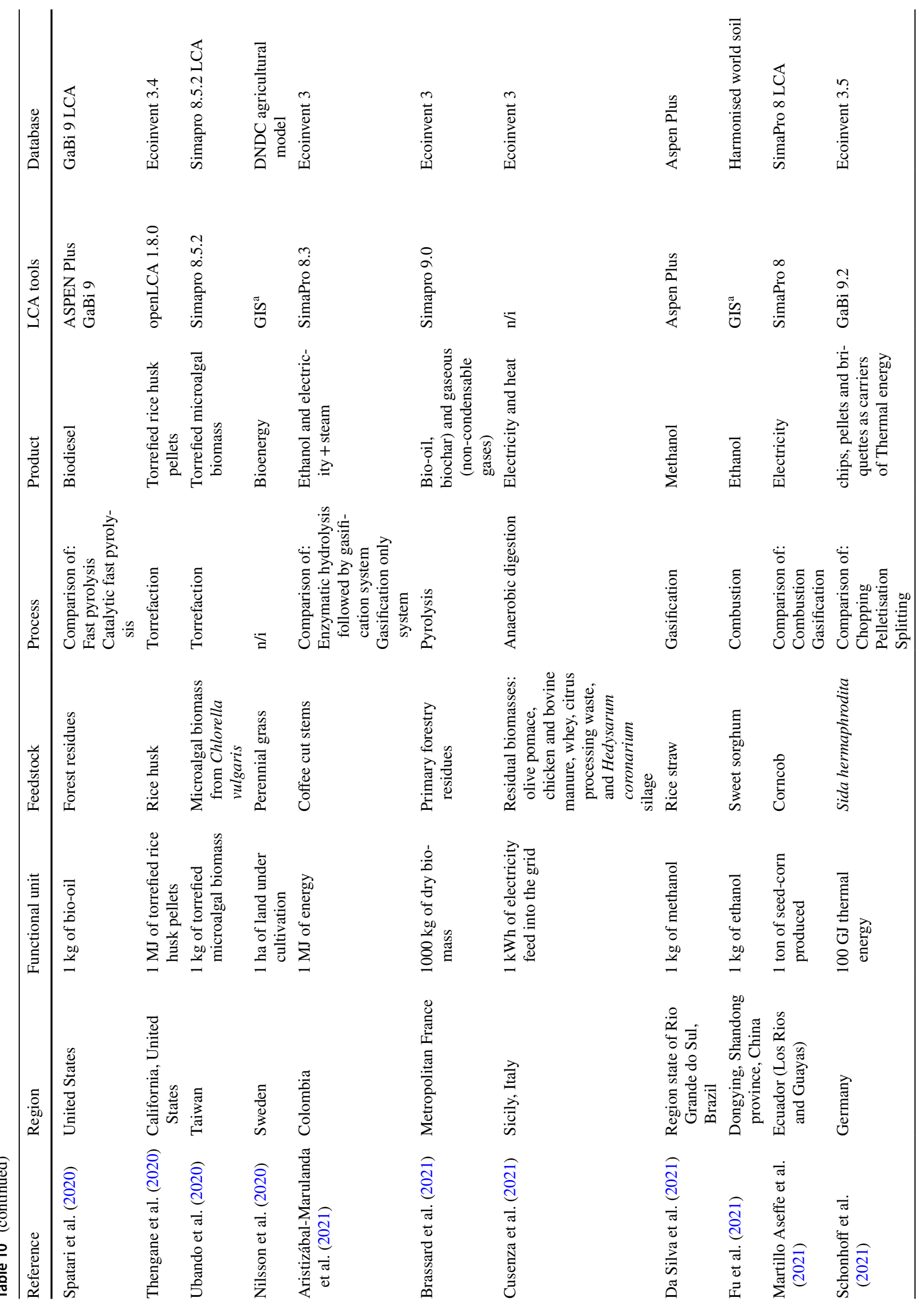




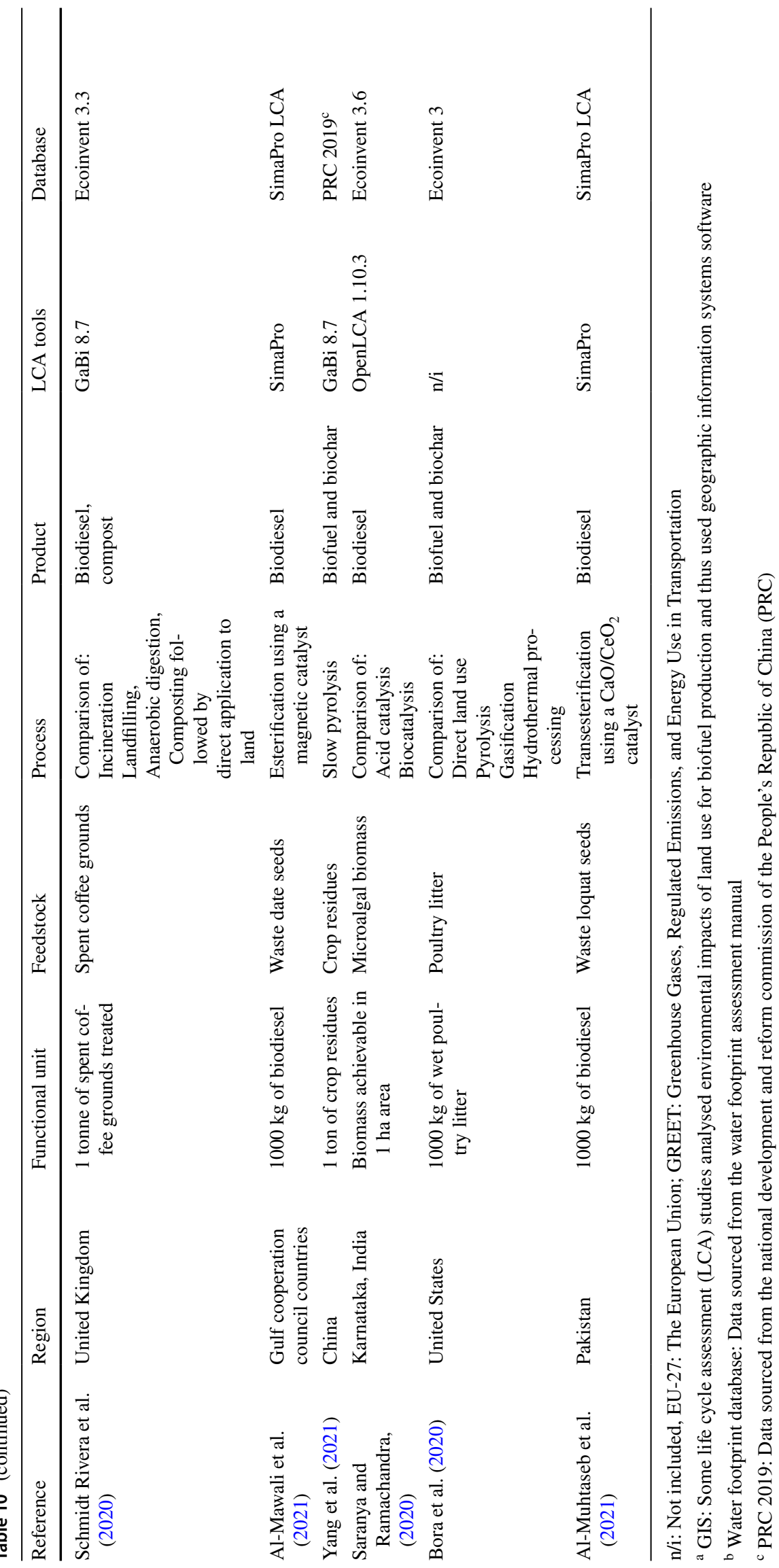


Fig. 4 Types of functional units used in the life cycle assessment studies reviewed in the present work $(N=40)$

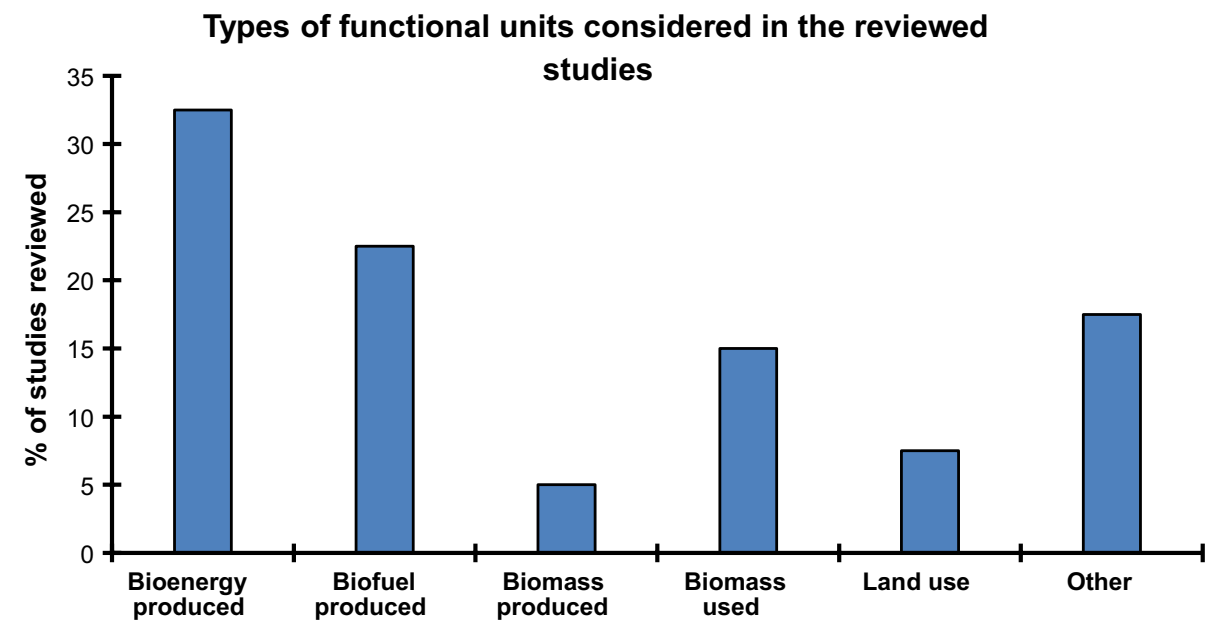

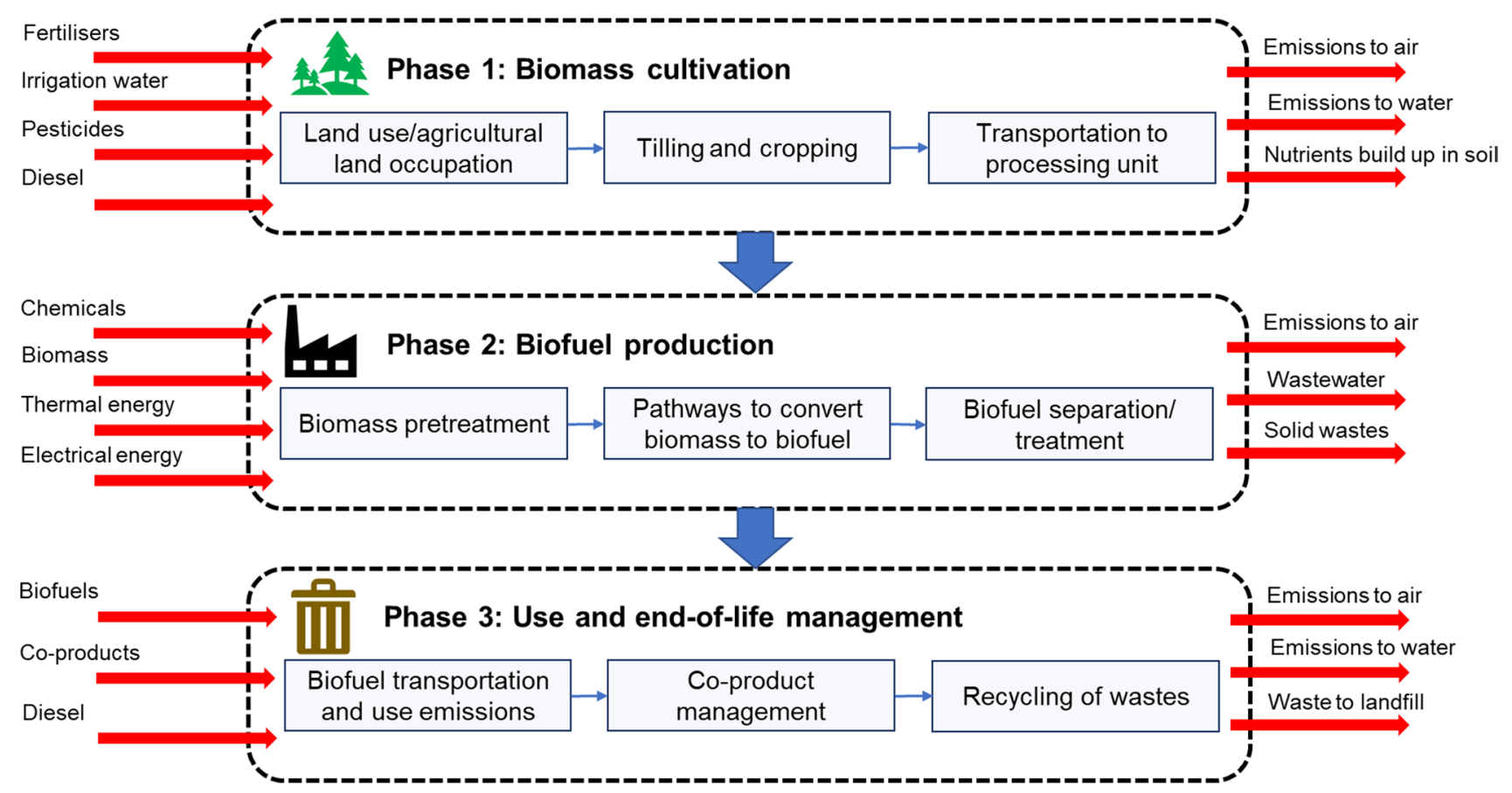

Fig. 5 General system boundary for conducting life cycle assessment of conversion of biomass feedstocks to biofuels

Fig. 6 Phases of system boundary considered for conducting life cycle assessment of converting biomass feedstocks into biofuels in the reviewed literature $(N=40)$
Phases of system boundary considered in the reviewed

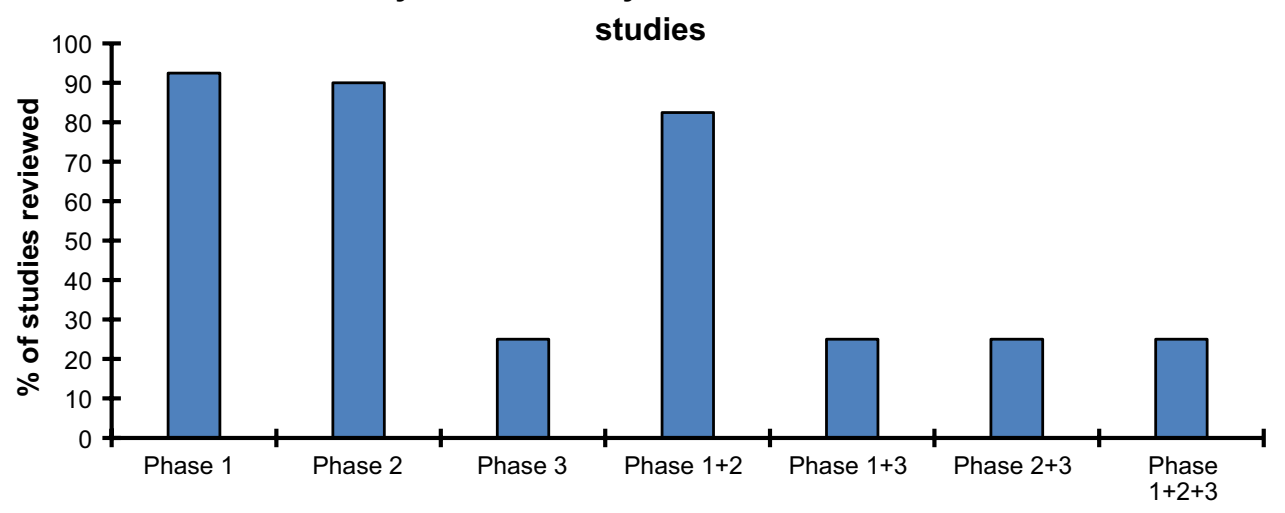




\section{Life cycle inventory analysis}

Inventory analysis involves quantifying all the inputs and outputs for the processes considered in the system boundary of the LCA. This includes raw material requirements, energy input, emissions to air, wastewater production, solid waste generation, emissions to land and others. It should be noted that more the systems involved in the system boundary, greater would be the need for data for inventory analysis, which also is explained in Fig. 6 with only some studies considering all the phases of biofuel production.

Table 10 shows databases for conducting inventory analysis, used in the reviewed studies such as SimaPro LCA databases, Ecoinvent, GREET (Greenhouse Gases, Regulated Emissions, and Energy Use in Transportation). Some LCA studies also used agricultural models for considering the impacts of land use on overall environmental sustainability, such as GLOBIOM, DNDC and STAMINA (Di Fulvio et al. 2019; Dupuis et al. 2019; Nilsson et al. 2020).

\section{Environmental impacts assessment}

\section{Mid-point indicators}

In this stage of LCA, key environmental impacts are quantified and distributed in various environmental categories depending upon the functional unit, system boundary, modelled systems and need of the decision-makers. Some studies computed net energy ratio to evaluate the usability of biofuels as energy sources (Al-Mawali et al. 2021; Al-Muhtaseb et al. 2021; Dasan et al. 2019; Im-Orb and Arpornwichanop 2020; Reaño 2020; Saranya and Ramachandra 2020), which is defined as the ratio of output energy to input energy for the overall process (Pleanjai and Gheewala 2009).

Mid-point categories used for expressing life cycle environmental impacts were: global warming potential (100 years), which includes greenhouse emissions is generally expressed as $\mathrm{kg} \mathrm{CO}_{2}$ equivalent for a time horizon of 100 years. Some studies also considered greenhouse gas emissions for a temporal scale of 20 years, in accordance with the life span of infrastructure (Aberilla et al. 2019; Cusenza et al. 2021). Abiotic depletion reported as $\mathrm{kg} \mathrm{Sb}$ equivalent corresponds to the depletion of fossil fuels, minerals, clay and peat. Abiotic depletion (fossil fuels, recorded as MJ) is linked to the depletion of fossil deposits. Ozone layer depletion ( $\mathrm{kg}$ trichlorofluoromethane equivalent) is typically accounted for a time scale of 40 years.

Ecotoxicity potential evaluated in $\mathrm{kg}$ 1,4 dichlorobenzene equivalent or cumulative toxic units is calculated in three separate categories, which examine damage to terrestrial, freshwater and marine sources for the entire production process. Photochemical oxidation recorded in kg non-methane volatile organic compounds equivalent refers to emissions of reactive substances injurious to human health and ecosystems. Acidification measured in $\mathrm{kg} \mathrm{SO}_{2}$ equivalent is caused by the emission of acidifying substances. Land use calculated in $\mathrm{m}^{2}$ is categorised as the transformation of urban land, agricultural land and natural land such as forests. Water depletion $\left(\mathrm{m}^{3}\right)$ is the use of water for the entire production chain of biofuels. Particulate matter formation expressed as PM2.5 equivalent and/or PM10 equivalent relates to the emission of PM 2.5 (particulate matter with $\leq 2.5 \mu \mathrm{m}$ in diameter) and/or PM10 (particulate matter with $\leq 10 \mu \mathrm{m}$ in diameter). Eutrophication consists of the effect of releasing an excessive amount of nutrients reported as $\mathrm{kg} \mathrm{PO}_{4}$ equivalent. Ionising radiation ( $\mathrm{kg} \mathrm{U} 235$ equivalent) transfers energy into the body tissue and may thereby interfere with the structure of molecules (Table 11).

Finally, human toxicity is recorded as $\mathrm{kg} \mathrm{1,4}$ dichlorobenzene equivalent or cumulative toxic units. Human toxicity (carcinogens) is an index that corresponds to potential harm of a unit of cancer-causing chemical released into the environment and is based on both the inherent toxicity of a compound and its potential dose. Human toxicity (non-carcinogens) index is associated with non-carcinogenic chemicals release, doses and exposure.

\section{Endpoint indicators}

The mid-point categories are aggregated to present results as endpoint categories. It is argued that the environmental impacts should be presented as mid-point categories to prevent oversimplification or misinterpretation of environmental impacts (Kalbar et al. 2017). Nevertheless, some studies did not present detailed mid-point indicator impacts but only endpoint indicators (Amezcua-Allieri et al. 2019; Martillo Aseffe et al. 2021; Bora et al. 2020).

The endpoint categories used in reviewed studies were: (1) human health (disability-adjusted life year) is related to the impacts of environmental degradation that results in an increase in and duration of loss of life years due to ill health, disability or early death, and (2) ecosystem quality (species $\times$ year) is linked to the impact of global warming potential, ozone layer depletion, acidification, ecotoxicity, eutrophication and indicates biodiversity loss. It is recorded as local species loss integrated over time, and (3) resources are related to the depletion of raw materials and energy sources expressed generally in US dollars (\$), representing the extra costs involved for future mineral and fossil resource extraction (Al-Muhtaseb et al. 2021).

\section{Uncertainty, scenario and sensitivity analysis}

Life cycle assessment (LCA) studies are models which are simplified versions of the real-world system and thus are inherently uncertain (Wang and Shen 2013). These 


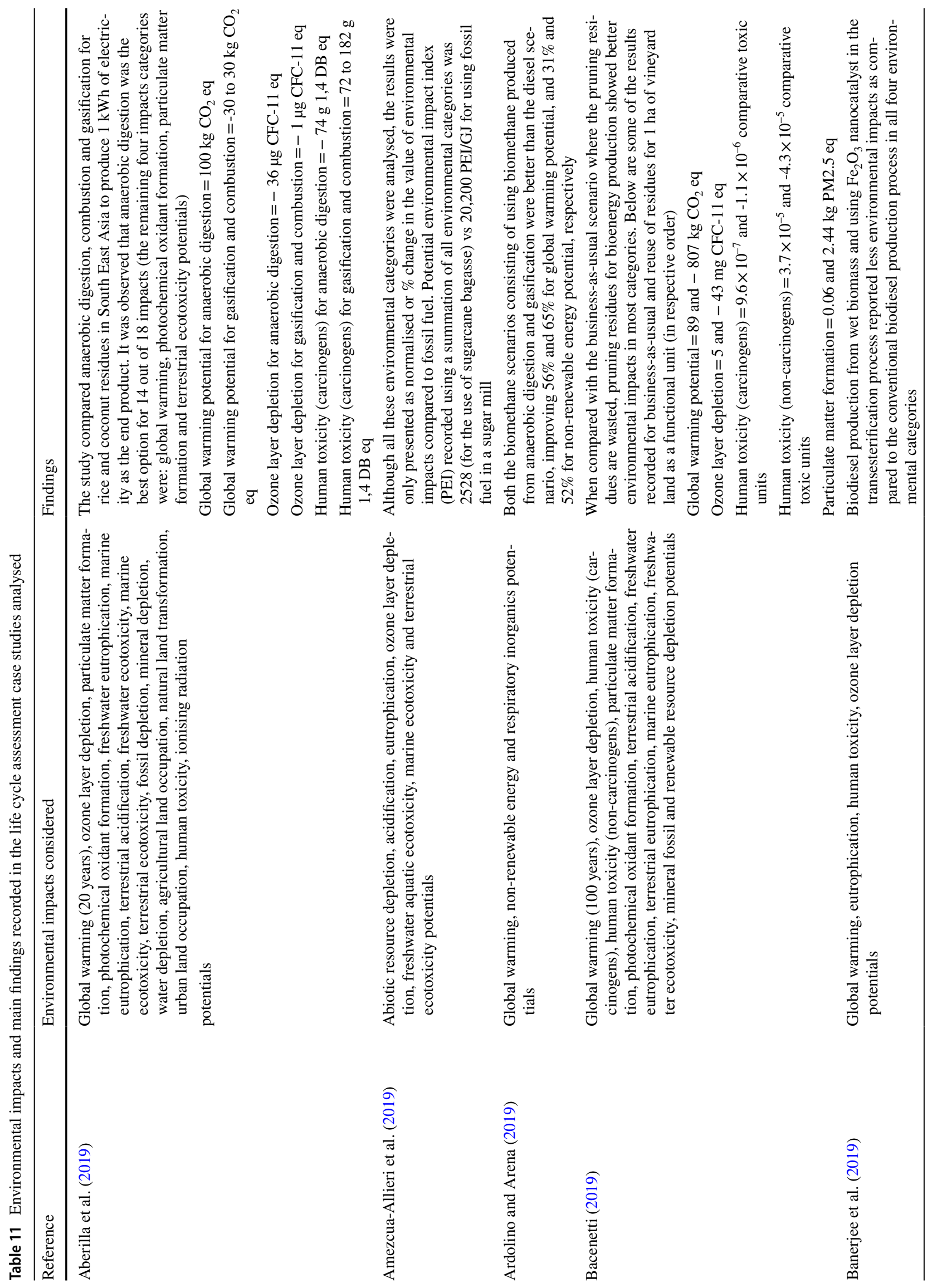




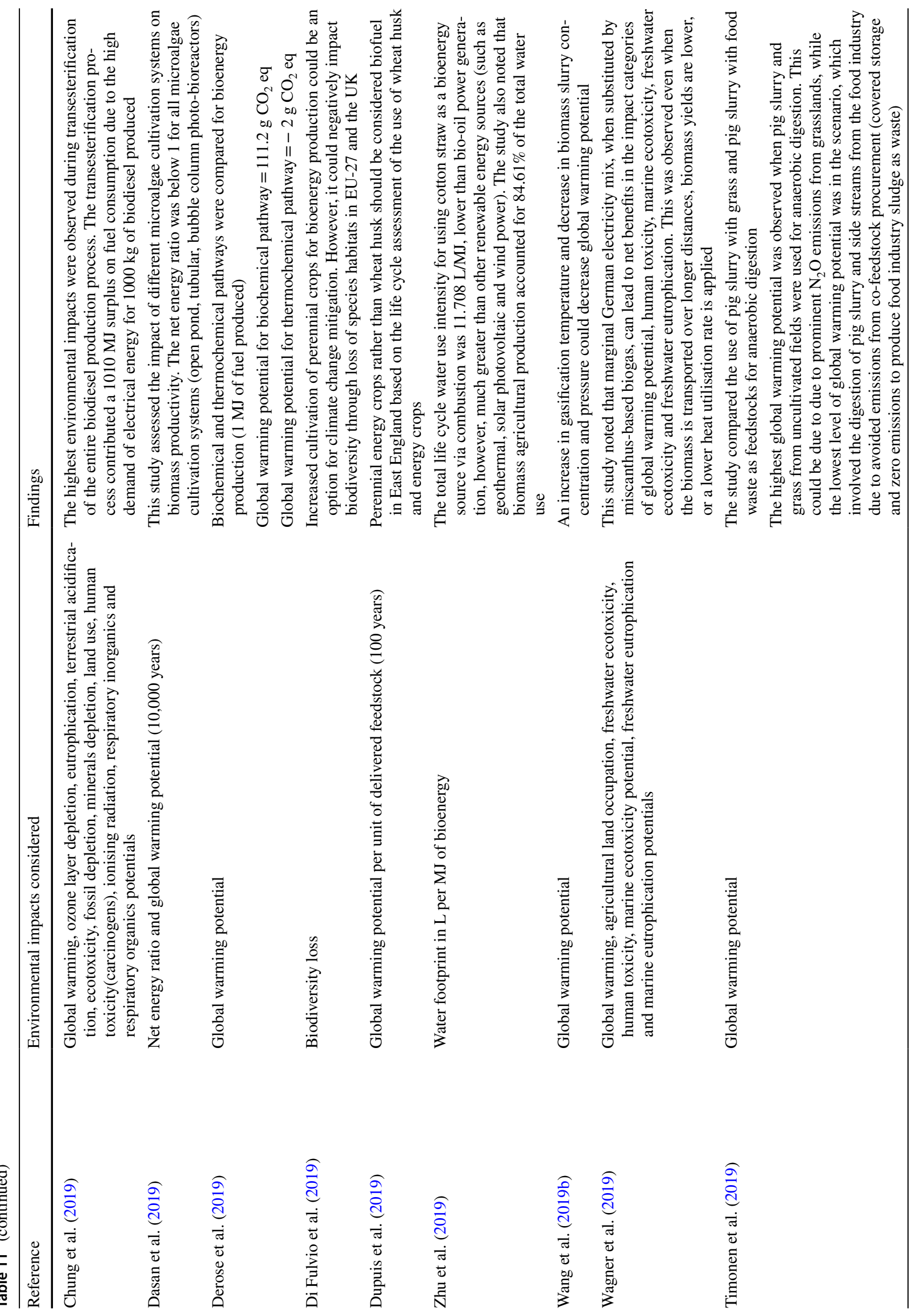




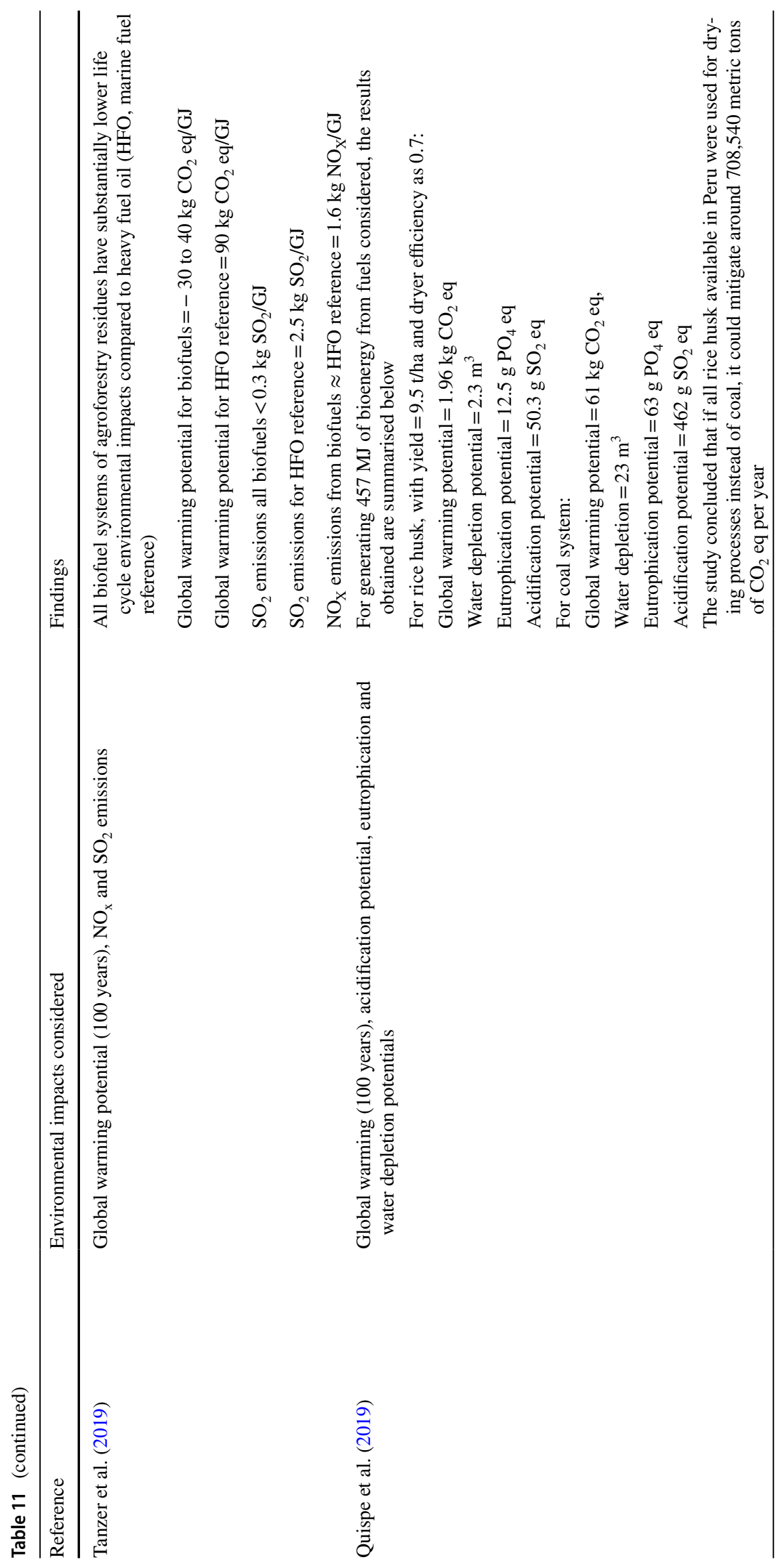




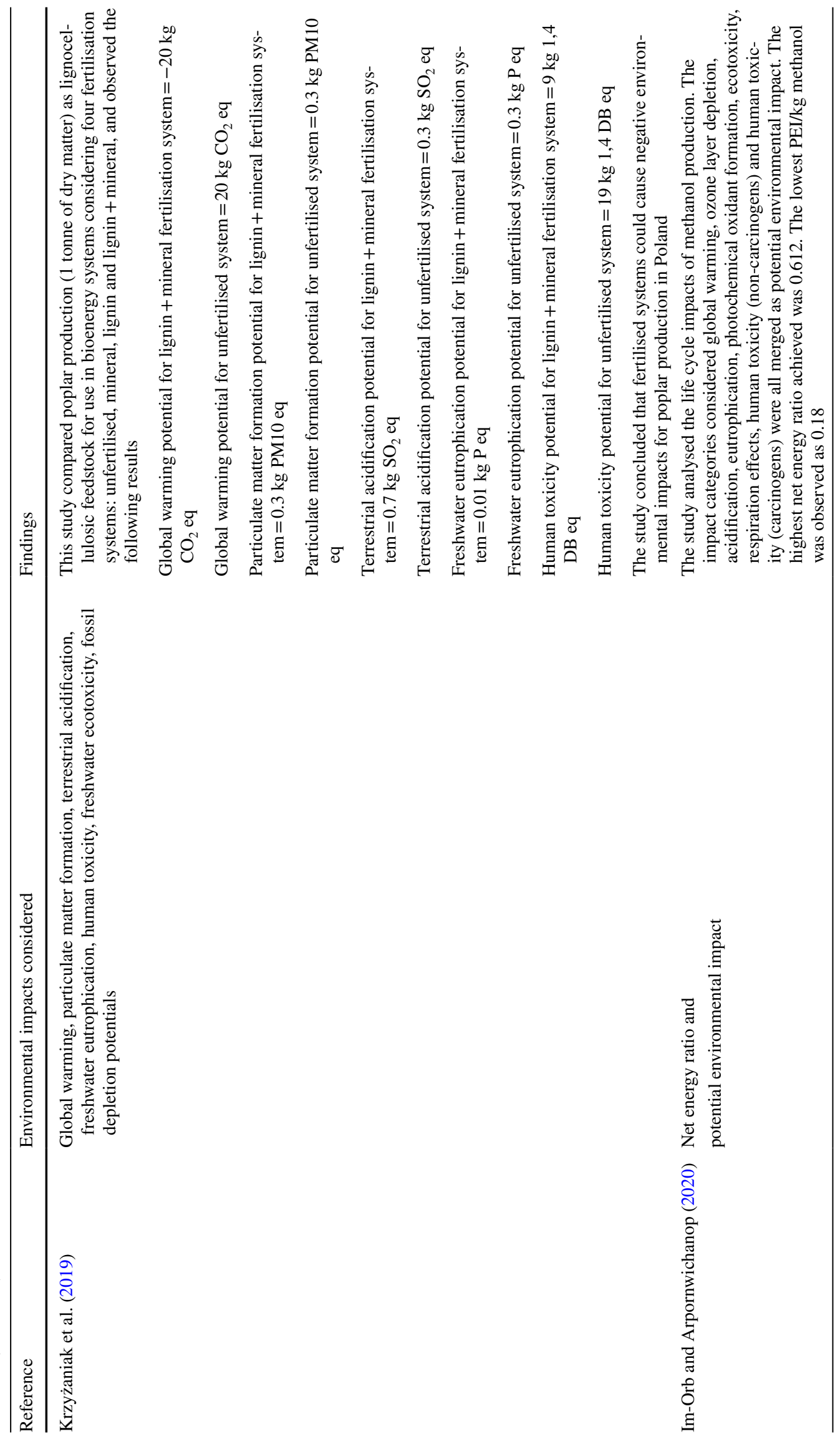




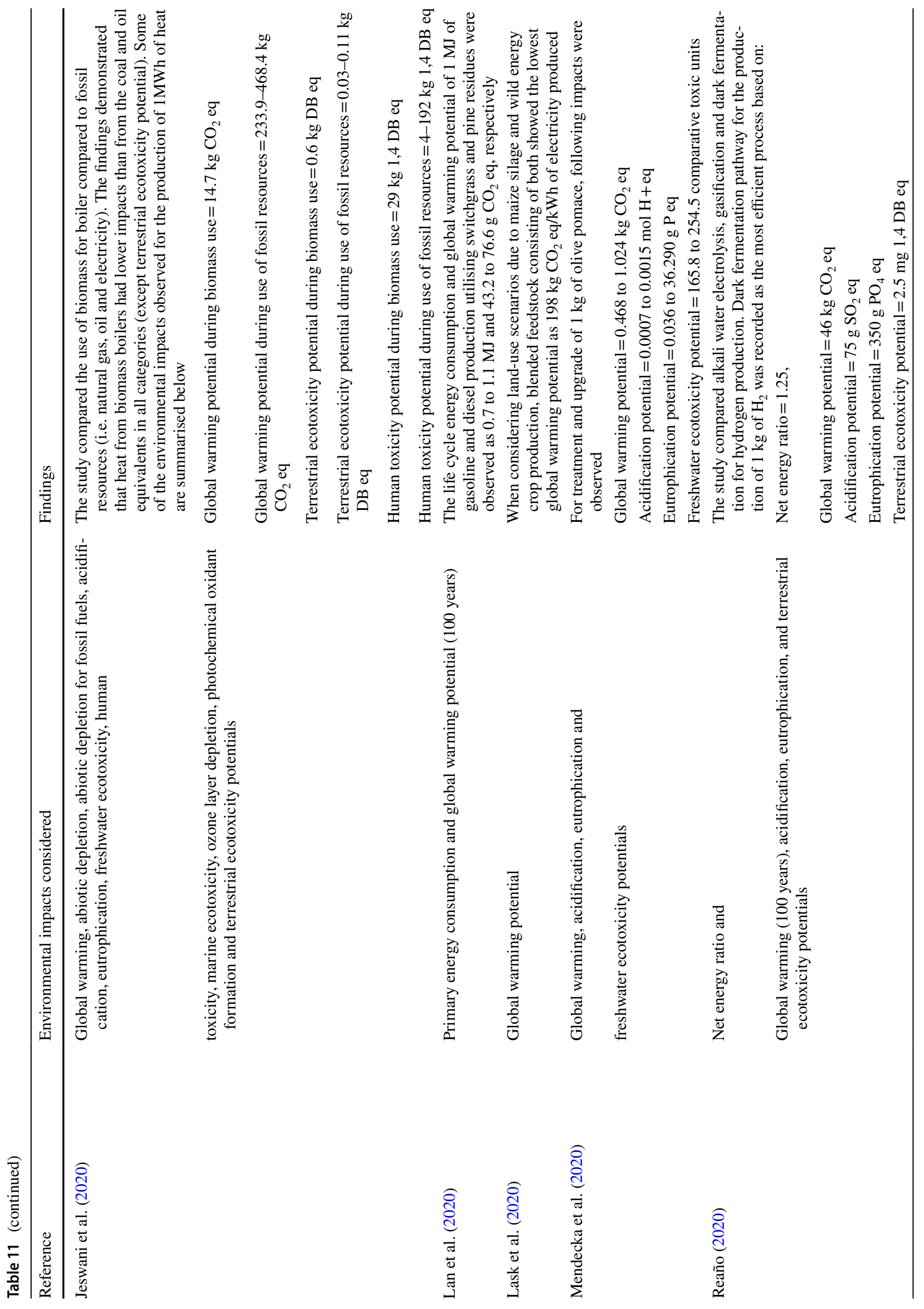




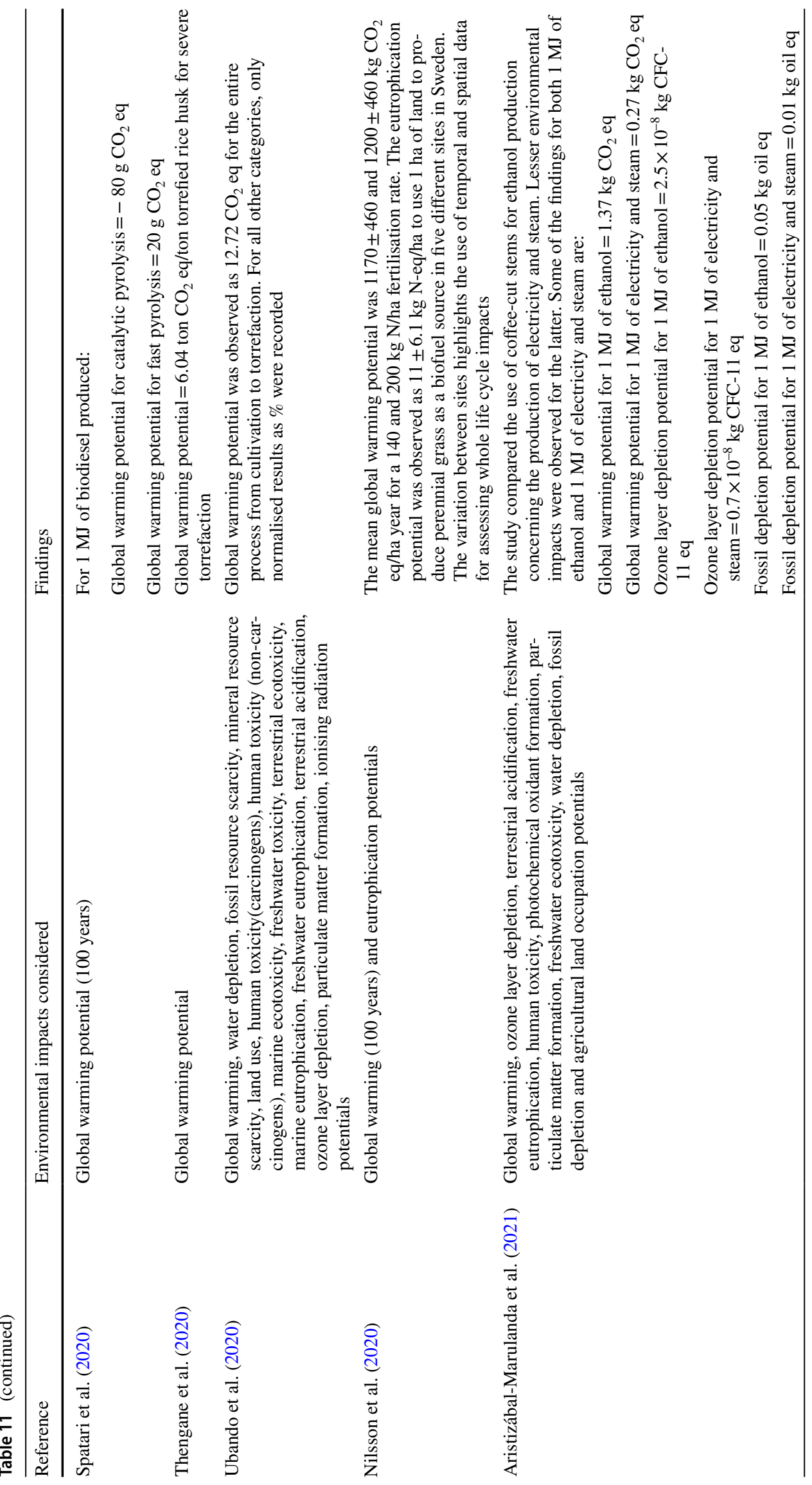




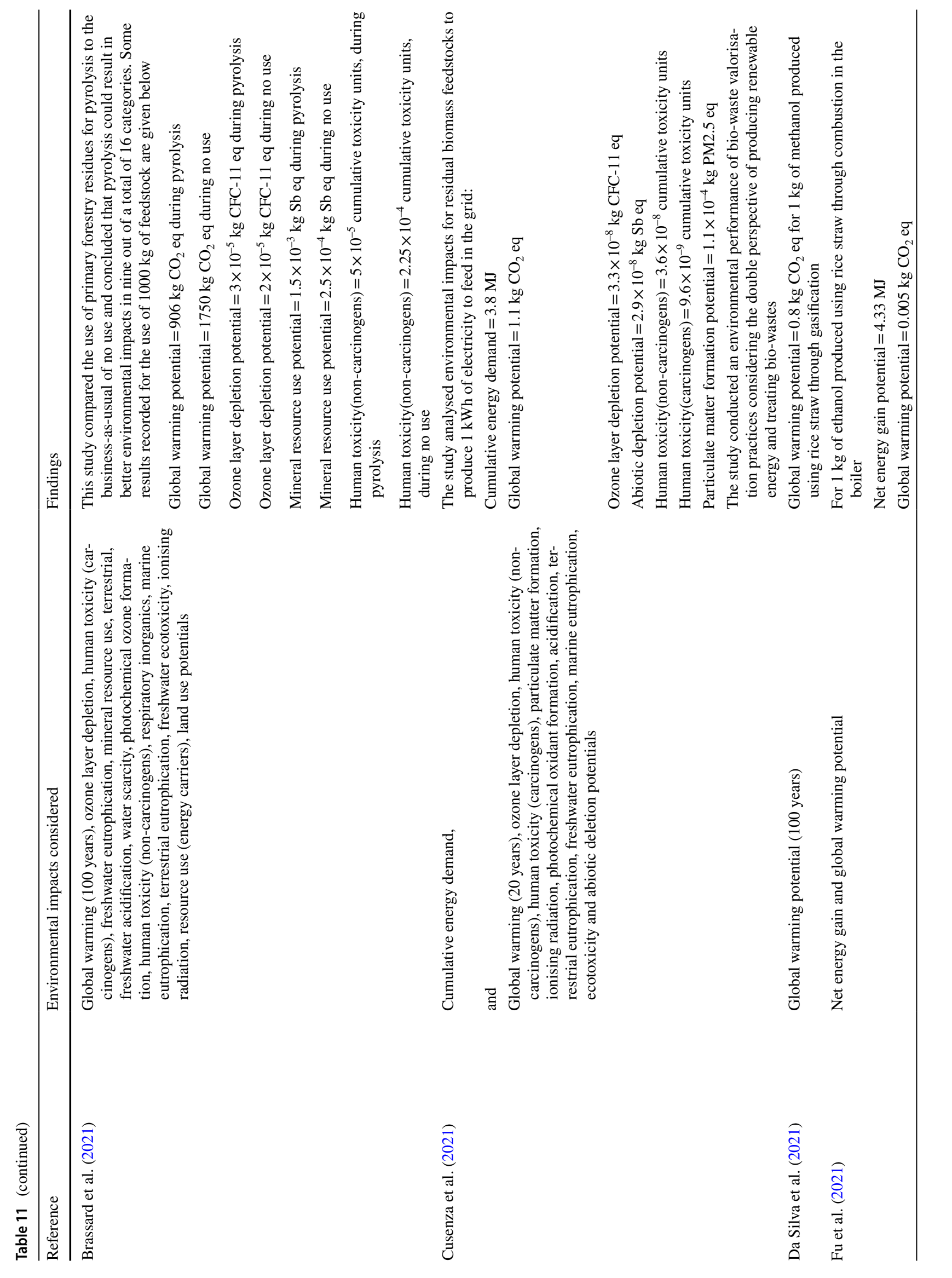




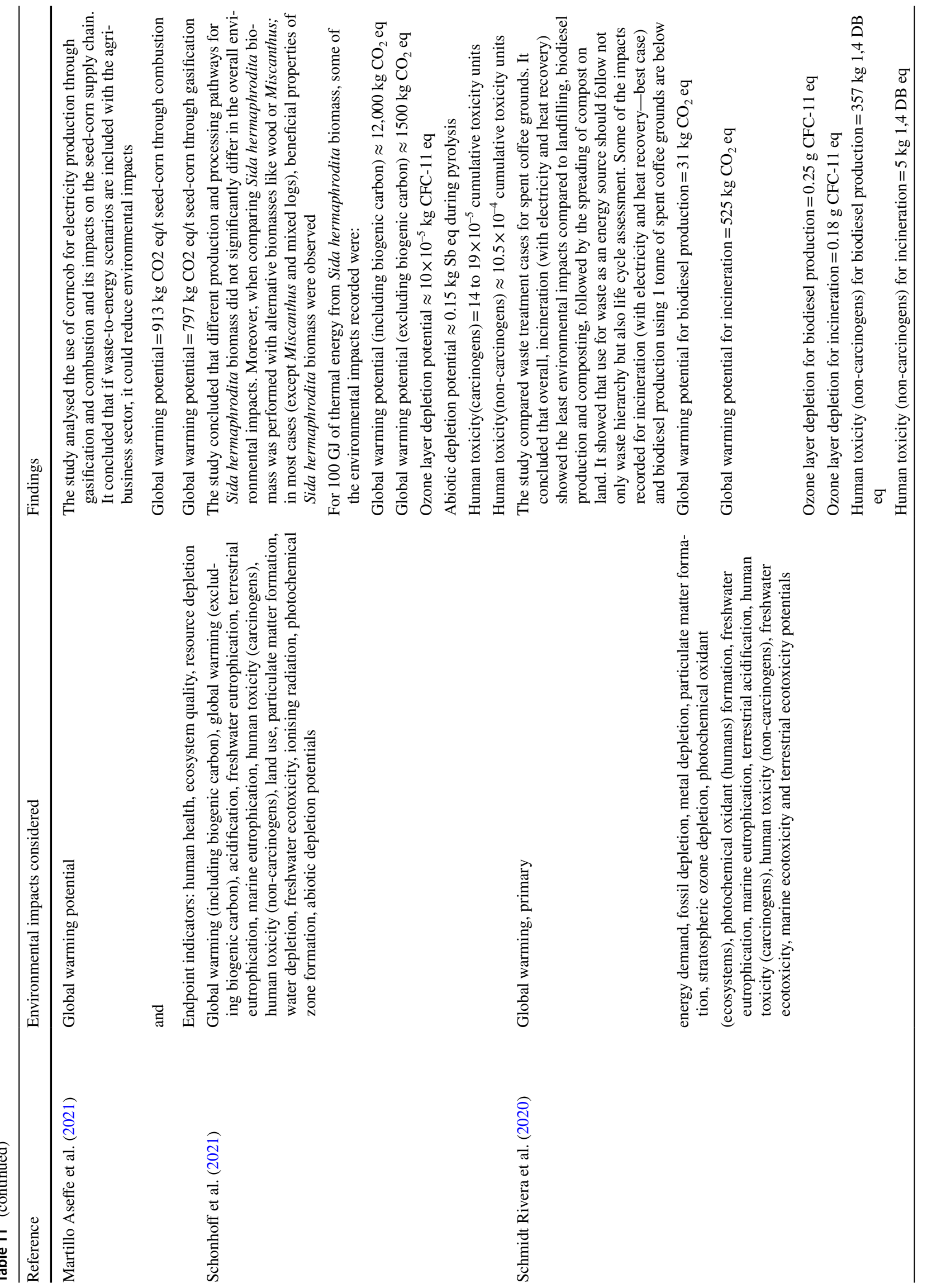




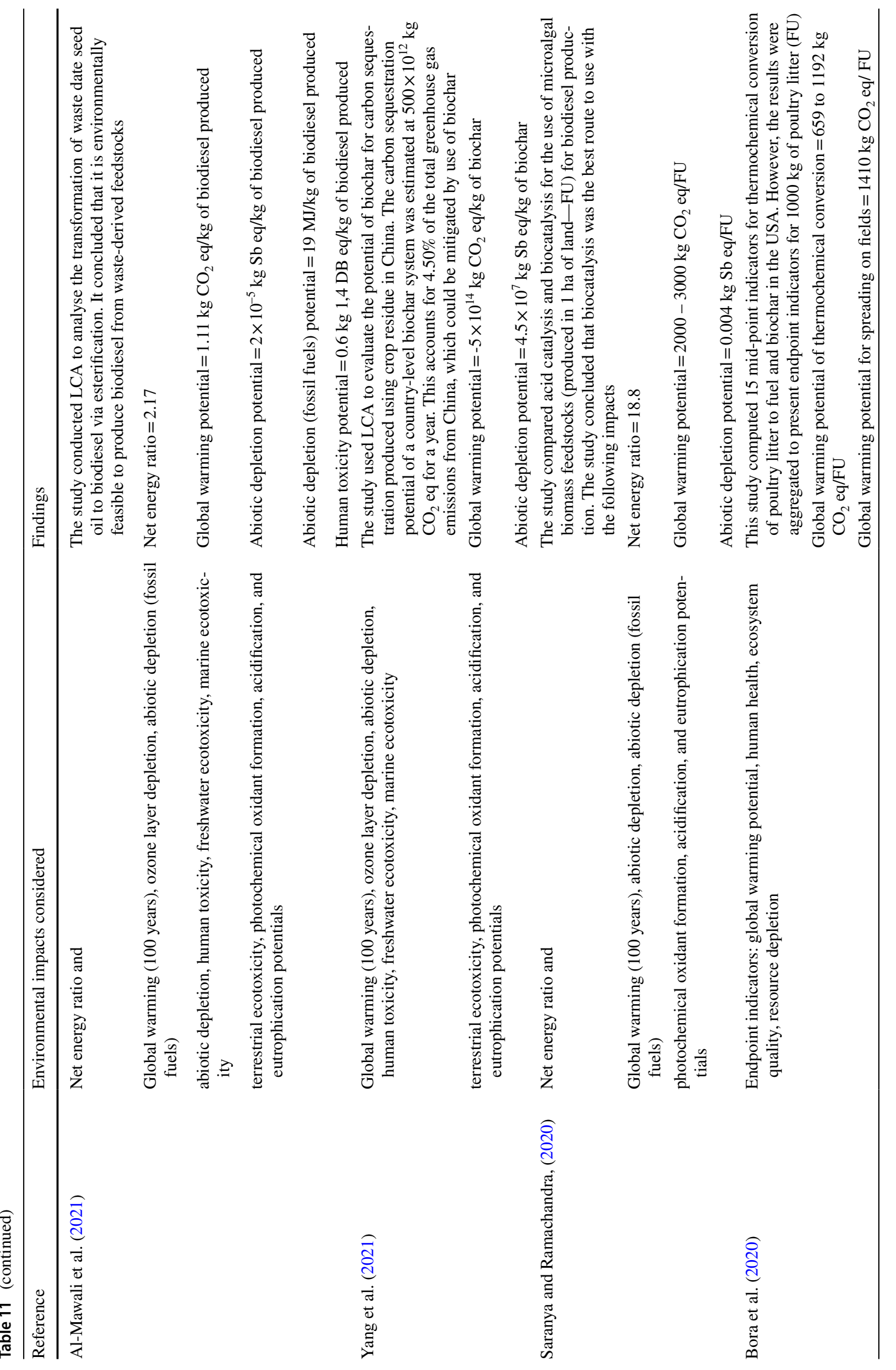


uncertainties arise due to statistical variation, subjective judgement, linguistic imprecision, variability in space and time, inherent randomness, expert disagreement and model approximations. These uncertainties can be propagated through the model using Monte Carlo simulations for parameter uncertainties or by considering different scenarios for biofuel production. Though it was noted that about $60 \%$ of the reviewed studies considered scenario analysis, only $10 \%$ of the studies did uncertainty analysis by accounting for parameter uncertainties (Fig. 7).

Sensitivity analysis identifies which process of the biodiesel production life cycle contributes directly to the burdensome environmental footprints. Relatedly, if impacts in environmental categories are to be minimised, these will be the processes where future research and development should focus on (Al-Muhtaseb et al. 2021). 50\% of the studies reviewed here conducted sensitivity analysis.

Therefore, for reliable and robust decision-making, it is necessary to analyse sensitivity and uncertainty for various scenarios. There were about ten studies identified with no analysis on sensitivity or uncertainty (due to parameters and scenarios). Moreover, the presence of only four studies with scenario, sensitivity and uncertainty analyses poses questions on the applicability of findings presented in the LCA studies. There was no study identified that included all three phases of the life cycle of biofuel production system boundary (described in Fig. 5) and uncertainty, scenario and sensitivity analyses in the 40 reviewed studies. This presents a considerable knowledge gap when it comes to the use of LCA studies for strategic decision-making.

\section{Interpretation of results}

This stage of the assessment includes making interpretations, drawing conclusions, identifying the phases or processes that can be improved in the life cycle of a biofuel production chain to improve the environmental feasibility of the environmental system. This stage could also involve presenting and communicating results to stakeholders.

\section{Key points observed in life cycle assessment studies}

We conducted an intensive critical review of 40 LCA studies, including methods and findings. In this section, we present key points observed in these studies.

There was no study identified that included all the three phases of biofuel production along with uncertainty, sensitivity and scenario analyses.

Moreover, most of the studies that computed net energy ratio (Al-Mawali et al. 2021; Al-Muhtaseb et al. 2021; Dasan et al. 2019; Im-Orb and Arpornwichanop 2020; Reaño 2020; Saranya and Ramachandra 2020), which is defined as the ratio of output energy/input energy for the overall process 
Fig. 7 Details of the scenario, sensitivity and uncertainty analyses conducted in the reviewed studies $(N=40)$
Scenario, sensitivity and uncertainty analyses conducted in the reviewed studies

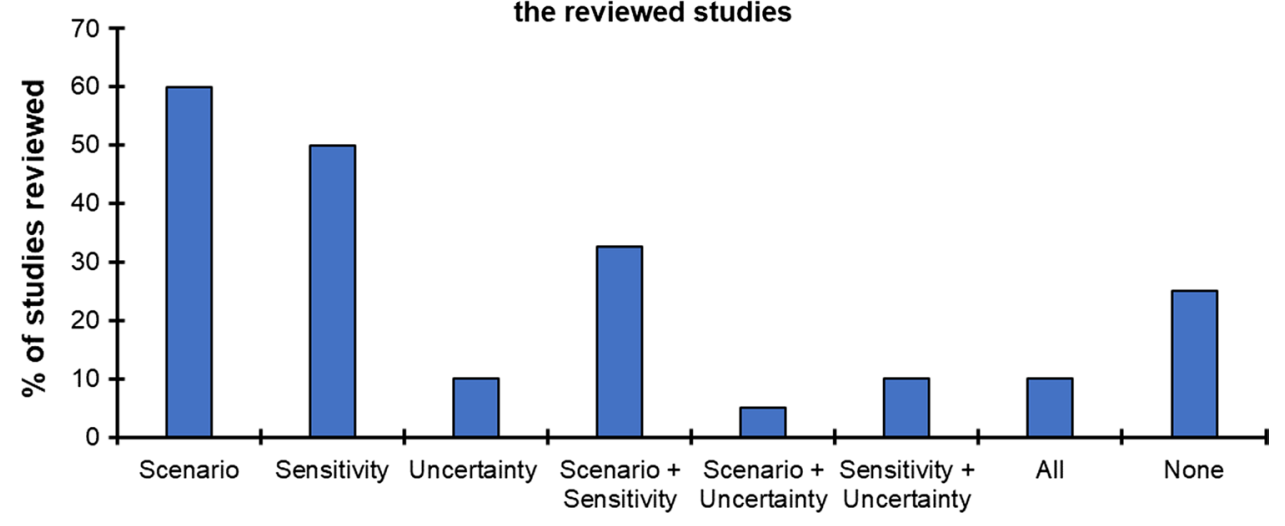

(Pleanjai and Gheewala 2009), recorded net energy ratio $>1$, showing the importance of biofuels as energy sources.

Generally recognised contentious issue to produce biofuels was land use which could occur due to natural land, agricultural and urban land transformation. This was highlighted by the fact that $7 \%$ of the studies used land use as a functional unit (Fig. 5); furthermore, about $15 \%$ of the reviewed studies analysed impacts on land use (Aberilla et al. 2019; Chung et al. 2019; Ubando et al. 2020; Aristizábal-Marulanda et al. 2021; Brassard et al. 2021; Schonhoff et al. 2021). It was also noted that the use of perennial energy crops is an interesting approach towards mitigation of greenhouse gas emissions; however, it could result in loss of biodiversity for the European Union and UK (EU-27 + UK) (Di Fulvio et al. 2019) (Table 11).

Other studies focused on water depletion and concluded that while producing biofuels can mitigate greenhouse gas emissions, it is also necessary to compute water depletion during crop production and biomass processing (Aberilla et al. 2019; Quispe et al. 2019; Ubando et al. 2020; Aristizábal-Marulanda et al. 2021; Schonhoff et al. 2021). In fact, Zhu et al. (2019) concluded that water depletion for biofuel production from cotton straws was lower than biooil power generation, however, much greater than observed for other renewable sources of energy (such as geothermal, solar photovoltaic and wind power). Most of the water use occurred due to biomass agricultural production, accounting for $84.6 \%$ of the total water use.

The impacts on land use and water depletion due to energy crop production show that waste-derived feedstocks could provide more sustainable energy sources. Waste-to-energy applications for biomass could mitigate the use of land, fertilisers and water for agriculture of energy crops. This is also in accordance with zero-waste hierarchy for management of waste biomass (Refuse/ redesign $>$ Reduce $>$ Reuse $>$ Recycle $>$ Material and chemicals recovery $>$ Residuals management $>$ Unacceptable, e.g. landfilling of non-stabilised waste/energy recovery) (Simon, 2019). In fact, there was only one study identified that highlighted that for spent coffee grounds, incineration is a better route compared to biofuel production (Schmidt Rivera et al. 2020).

Finally, focusing on the comparison of biological and thermochemical pathways, in general, it was observed in the comparative studies that thermochemical processes showed lesser environmental impacts compared to biological processes for the same biomass and geographical and temporal span (Ardolino and Arena 2019; Derose et al. 2019). Even in Aberilla et al. (2019), which showed higher environmental impacts in the thermochemical process, the greenhouse gas emissions for gasification were lower than that of anaerobic digestion for rice and coconut residues.

\section{Bibliometric analysis}

Figure 8a, b depicts the bibliometric analysis mapping originated from the Web of Science core collection for the network visualisation and density visualisation, respectively. Firstly, the data were exported 500 entries at a time of 9947 results and then were fed into the VOSviewer software that plotted the data. The type of analysis used herein was cooccurrence, and all keywords were included, as well as the fractional counting method. We observed direct clusters connecting identifiable keywords to broad topics such as thermochemical, biochemical and processes associated with those two routes (gasification, pyrolysis, hydrothermal liquefaction, combustion, torrefaction, anaerobic digestion and fermentation). This enabled the visualisation of most of the significant keywords in publications in the period of 1970-2021 that were associated with the thermochemical and biochemical conversion routes of biomass.

It is evident from Fig. 8a, b that keywords that have seen a significant increase in popularity and, as a result, progress in keyword research such as biomass gasification, pyrolysis and combustion as they part of the thermochemical route in biomass conversion. In addition, other correlated keywords 


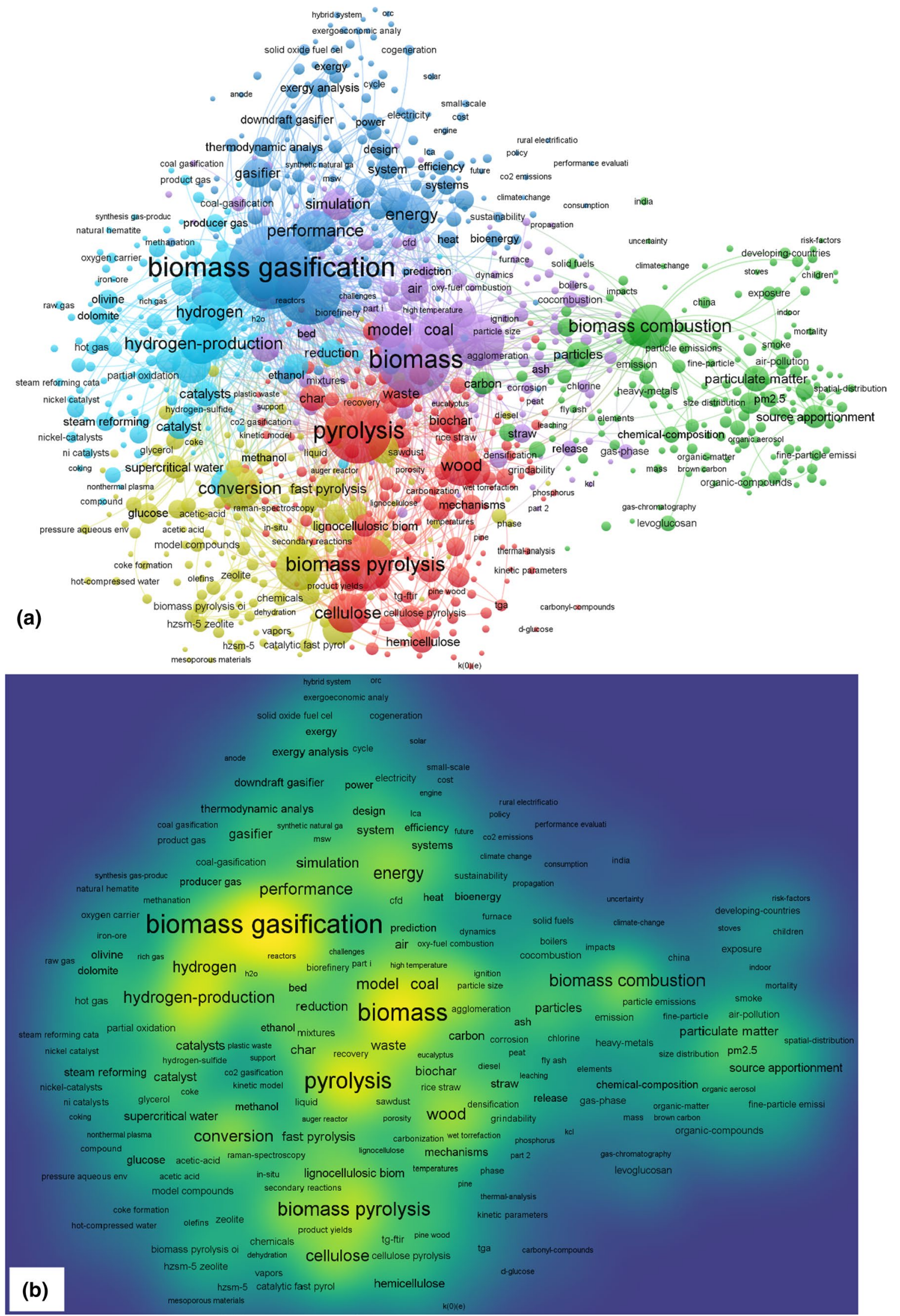


4Fig. 8 Bibliometric mapping of biomass conversion processes into biofuels a network visualisation and $\mathbf{b}$ density visualisation maps. The bibliometric mapping was performed between 1970 and 2021

have shown in the bibliometric mapping, such as hydrogen production, catalysts and fuel performance. This signifies that the process of thermochemical conversion is at a very mature stage in terms of research and development, as demonstrated by the prominence of publication keywords over the last 51 years. Because of its higher productivity, economic viability and existing infrastructure compatibility resources, it is ultimately readily available and easily scaled up for the industrial sector.

Although gasification appears to be most researched in the thermochemical route, this could be down to the fact that gasification technology has existed longer than counterpart technologies, apart from combustion. This also does not indicate that it is the most efficient thermochemical technology in process efficiency and product quality. For example, when using gasification, there is a need to remove the hydrogen sulphide and clean the synthesis gas produced and other requirements.

On the other hand, the biochemical conversion route is less favourable since it suffers from certain limitations, such as its time-consuming process and low product yield and product inhabitation. Biochemical conversion keywords are shown in Fig. 8a, b, such as ethanol production, bio-hydrogen and others.

\section{Conclusion}

Biomass as an affordable, reliable and sustainable energy source contributes $9 \%(\sim 51 \mathrm{EJ})$ of the global overall primary energy supply. Thermochemical and biochemical technologies are the two main routes employed to convert biomass into biofuels. The former route includes hydrothermal liquefaction, pyrolysis, torrefaction, gasification and combustion processes, while the latter route consists of fermentation and anaerobic digestion processes.

Herein, we critically reviewed each individual route along with the integration between hydrothermal and biochemical routes of biomass utilisation from a bioeconomy perspective. Both routes have drawbacks: the former method usually involves a high energy intake along with solvent or catalyst addition. In contrast, the latter route has a lengthy cycle period and is less efficient in breaking down recalcitrant biomass materials. Thus, combining those two routes can be promising by incorporating the benefits of both methods in biofuel processing. However, there are outstanding challenges associated with integration between those two routes. For instance, the catalysts or solvent utilisation of the thermochemical route can result in poisoning or killing the microorganism or generate various inhibitors that can affect the biological progress routes. Furthermore, this integration may lead to additional costs.

Moreover, to understand the recent advances in evaluating environmental impacts due to biofuel production, we conducted an intensive critical review of 40 life cycle assessment (LCA) studies published from the years 2019-2021, including methods and findings. The important methods and key findings observed were:

1. Only eight studies included all three phases of biofuel production (which includes biomass cultivation, biofuel production process and biofuel use and end-of-life management phase).

2. Waste-derived feedstocks could provide more sustainable energy sources by mitigating impacts on land use and water depletion incurred during the production of energy crops.

3. Focusing on thermochemical and biological processes for the same biomass feedstock and geographical and temporal span, thermochemical processes caused lesser greenhouse gas emissions compared to biological pathways.

This review has suggested interesting new avenues for evaluation of environmental impacts of the biofuel production chain and key outcomes from a range of biofuel production processes. Based on the bibliometric mapping (network and density visualisation maps) from the Web of Science core collection, we have identified that the thermochemical conversion route of biomass is more researched and far outweighed and understood than the biochemical counterpart route of research outputs. This indicates that the biochemical route suffers from specific gaps in the research, as shown from the lack of impact in the bibliometric mapping analysis, thus opening doors for a scope for further research in this area.

Funding The authors would like to thank OQ Oman for their generous financial support (project code: CR/DVC/SERC/19/01). The authors would also like to acknowledge the support of the Sustainable Energy Research Centre at Sultan Qaboos University. Ahmed Osman and David Rooney wish to acknowledge the support of The Bryden Centre project (Project ID VA5048). The Bryden Centre project is supported by the European Union's INTERREG VA Programme, managed by the Special EU Programmes Body (SEUPB). Neha Mehta acknowledges funding from the Centre for Advanced Sustainable Energy, Belfast, UK.

\section{Declarations}

Conflict of interest The authors declare no conflict of interest. 
Ethical approval The views and opinions expressed in this review do not necessarily reflect those of the European Commission or the Special EU Programmes Body (SEUPB).

Open Access This article is licensed under a Creative Commons Attribution 4.0 International License, which permits use, sharing, adaptation, distribution and reproduction in any medium or format, as long as you give appropriate credit to the original author(s) and the source, provide a link to the Creative Commons licence, and indicate if changes were made. The images or other third party material in this article are included in the article's Creative Commons licence, unless indicated otherwise in a credit line to the material. If material is not included in the article's Creative Commons licence and your intended use is not permitted by statutory regulation or exceeds the permitted use, you will need to obtain permission directly from the copyright holder. To view a copy of this licence, visit http://creativecommons.org/licenses/by/4.0/.

\section{References}

Aberilla JM et al (2019) Environmental sustainability of small-scale biomass power technologies for agricultural communities in developing countries. Renewable Energy 141:493-506. https:// doi.org/10.1016/j.renene.2019.04.036

Abou Rjeily M et al (2021) Pyrolysis-catalytic upgrading of bio-oil and pyrolysis-catalytic steam reforming of biogas: a review. Environ Chem Lett. https://doi.org/10.1007/ s10311-021-01190-2

Adelabu BA et al (2019) Bioconversion of corn straw to ethanol by cellulolytic yeasts immobilized in Mucuna urens matrix. Journal of King Saud University Science 31:136-141. https:// doi.org/10.1016/j.jksus.2017.07.005

Ahmad AA et al (2016) Assessing the gasification performance of biomass: a review on biomass gasification process conditions, optimization and economic evaluation. Renew Sustain Energy Rev 53:1333-1347. https://doi.org/10.1016/j.rser.2015.09.030

Ahmad Ansari F et al (2020) Techno-economic feasibility of algal aquaculture via fish and biodiesel production pathways: A commercial-scale application. Sci Total Environ 704:135259. https://doi.org/10.1016/j.scitotenv.2019.135259

Akalın MK et al (2017) Supercritical fluid extraction of biofuels from biomass. Environ Chem Lett 15:29-41. https://doi.org/ 10.1007/s10311-016-0593-z

Al-Mawali KS et al (2021) Life cycle assessment of biodiesel production utilising waste date seed oil and a novel magnetic catalyst: A circular bioeconomy approach. Renewable Energy 170:832-846. https://doi.org/10.1016/j.renene.2021.02.027

Al-Muhtaseb A, a. H., et al (2021) Circular economy approach of enhanced bifunctional catalytic system of $\mathrm{CaO} / \mathrm{CeO} 2$ for biodiesel production from waste loquat seed oil with life cycle assessment study. Energy Convers Manage. https://doi.org/10. 1016/j.enconman.2021.114040

Alvira P et al (2010) Pretreatment technologies for an efficient bioethanol production process based on enzymatic hydrolysis: a review. Biores Technol 101:4851-4861. https://doi.org/ 10.1016/j.biortech.2009.11.093

Al-Wahaibi A et al (2020) Techno-economic evaluation of biogas production from food waste via anaerobic digestion. Sci Rep 10:15719. https://doi.org/10.1038/s41598-020-72897-5

Amezcua-Allieri MA et al (2019) Techno-economic analysis and life cycle assessment for energy generation from sugarcane bagasse: case study for a sugar mill in Mexico. Food Bioprod Process 118:281-292. https://doi.org/10.1016/j.fbp.2019.09.014
Anastasakis K, Ross AB (2015) Hydrothermal liquefaction of four brown macro-algae commonly found on the UK coasts: an energetic analysis of the process and comparison with biochemical conversion methods. Fuel 139:546-553. https://doi. org/10.1016/j.fuel.2014.09.006

Antoniou N, Zabaniotou A (2013) Features of an efficient and environmentally attractive used tyres pyrolysis with energy and material recovery. Renew Sustain Energy Rev 20:539-558. https://doi.org/10.1016/j.rser.2012.12.005

Aravind S et al (2020) Conversion of green algal biomass into bioenergy by pyrolysis. A Review Environmental Chemistry Letters 18:829-849. https://doi.org/10.1007/s10311-020-00990-2

Ardolino F, Arena U (2019) Biowaste-to-Biomethane: an LCA study on biogas and syngas roads. Waste Manage 87:441-453. https://doi.org/10.1016/j.wasman.2019.02.030

Aristizábal-Marulanda V et al (2021) Environmental assessment of energy-driven biorefineries: the case of the coffee cutstems (CCS) in Colombia. The International Journal of Life Cycle Assessment 26:290-310. https://doi.org/10.1007/ s11367-020-01855-0

Aro EM (2016) From first generation biofuels to advanced solar biofuels. Ambio 45:24-31. https://doi.org/10.1007/ s13280-015-0730-0

Arun J et al (2021) Technical insights into the production of green fuel from $\mathrm{CO} 2$ sequestered algal biomass: a conceptual review on green energy. Sci Total Environ 755:142636-142636. https:// doi.org/10.1016/j.scitotenv.2020.142636

Astrup TF et al (2015) Life cycle assessment of thermal waste-toenergy technologies: review and recommendations. Waste Manage 37:104-115. https://doi.org/10.1016/j.wasman.2014.06.011

Atimtay AT (2010) Combustion of agro-waste with coal in a fluidized bed. Clean Technol Environ Policy 12:43-52. https://doi.org/10. 1007/s10098-009-0220-9

Aysu T et al (2016) Bio-oil production via catalytic pyrolysis of Anchusa azurea: effects of operating conditions on product yields and chromatographic characterization. Biores Technol 205:7-14. https://doi.org/10.1016/j.biortech.2016.01.015

Azizi K et al (2018) A review on bio-fuel production from microalgal biomass by using pyrolysis method. Renew Sustain Energy Rev 82:3046-3059. https://doi.org/10.1016/j.rser.2017.10.033

Bacenetti J (2019) Heat and cold production for winemaking using pruning residues: environmental impact assessment. Appl Energy 252:113464. https://doi.org/10.1016/j.apenergy.2019.113464

Bach QV, Skreiberg O (2016) Upgrading biomass fuels via wet torrefaction: A review and comparison with dry torrefaction. Renew Sustain Energy Rev 54:665-677. https://doi.org/10.1016/j.rser. 2015.10.014

Balajii M, Niju S (2019) Biochar-derived heterogeneous catalysts for biodiesel production. Environ Chem Lett 17:1447-1469. https:// doi.org/10.1007/s10311-019-00885-x

Balat $M$ et al (2008) Progress in bioethanol processing. Prog Energy Combust Sci 34:551-573. https://doi.org/10.1016/j.pecs.2007. 11.001

Banerjee $\mathrm{S}$ et al (2019) Fe2O3 nanocatalyst aided transesterification for biodiesel production from lipid-intact wet microalgal biomass: a biorefinery approach. Energy Convers Manage 195:844-853. https://doi.org/10.1016/j.enconman.2019.05.060

Barskov S et al (2019) Torrefaction of biomass: a review of production methods for biocoal from cultured and waste lignocellulosic feedstocks. Renewable Energy 142:624-642. https://doi.org/10. 1016/j.renene.2019.04.068

Beims RF et al. (2020) Hydrothermal liquefaction of biomass to fuels and value-added chemicals: Products applications and challenges to develop large-scale operations. biomass and Bioenergy. 135, 105510-105510. https://doi.org/10.1016/j.biombioe. 2020.105510 
Ben-Iwo J et al (2016) Biomass resources and biofuels potential for the production of transportation fuels in Nigeria. Renew Sustain Energy Rev 63:172-192. https://doi.org/10.1016/j.rser.2016.05. 050

Bharti MK et al (2021) Nanoferrites heterogeneous catalysts for biodiesel production from soybean and canola oil: a review. Environ Chem Lett. https://doi.org/10.1007/s10311-021-01247-2

Bora RR et al (2020) Life cycle assessment and technoeconomic analysis of thermochemical conversion technologies applied to poultry litter with energy and nutrient recovery. ACS Sustain Chem Eng 8:8436-8447. https://doi.org/10.1021/acssuschemeng.0c02860

Borjesson PII (1996) Energy analysis of biomass production and transportation. Biomass Bioenerg 11:305-318. https://doi.org/ 10.1016/0961-9534(96)00024-4

Brassard P et al (2021) Framework for consequential life cycle assessment of pyrolysis biorefineries: a case study for the conversion of primary forestry residues. Renew Sustain Energy Rev 138:110549. https://doi.org/10.1016/j.rser.2020.110549

Bridgeman TG et al (2008) Torrefaction of reed canary grass, wheat straw and willow to enhance solid fuel qualities and combustion properties. Fuel 87:844-856. https://doi.org/10.1016/j.fuel. 2007.05.041

Bridgwater AV (2012a) Review of fast pyrolysis of biomass and product upgrading. Biomass Bioenerg 38:68-94. https://doi.org/10. 1016/j.biombioe.2011.01.048

Bridgwater AV (2012b) Upgrading Biomass Fast Pyrolysis Liquids. Environ Prog Sustainable Energy 31:261-268. https://doi.org/ 10.1002/ep. 11635

Bulushev DA, Ross JRH (2011) Catalysis for conversion of biomass to fuels via pyrolysis and gasification: a review. Catal Today 171:1-13. https://doi.org/10.1016/j.cattod.2011.02.005

Cahyanti MN et al (2020) Biomass torrefaction: an overview on process parameters, economic and environmental aspects and recent advancements. Bioresour Technol 301:122737-122737. https:// doi.org/10.1016/j.biortech.2020.122737

Cai WZ et al (2019) Plastic waste fuelled solid oxide fuel cell system for power and carbon nanotube cogeneration. Int J Hydrogen Energy 44:1867-1876. https://doi.org/10.1016/j.ijhydene.2018. 11.159

Caporgno MP et al (2016) Hydrothermal liquefaction of nannochloropsis oceanica in different solvents. Biores Technol 214:404-410. https://doi.org/10.1016/j.biortech.2016.04.123

Chai $\mathrm{Y}$ et al (2020) $\mathrm{H}_{2}$ production from co-pyrolysis/gasification of waste plastics and biomass under novel catalyst $\mathrm{Ni}-\mathrm{CaO}-\mathrm{C}$. Chem Eng J 382:122947. https://doi.org/10.1016/j.cej.2019.122947

Chaluvadi S et al (2019) Effect of torrefaction prior to biomass size reduction on ethanol production. Waste Biomass Valorization 10:3567-3577. https://doi.org/10.1007/s12649-018-0389-4

Chamkalani A et al (2020) A critical review on life cycle analysis of algae biodiesel: current challenges and future prospects. Renew Sustain Energy Rev 134:110143. https://doi.org/10.1016/j.rser. 2020.110143

Chan YH et al (2019) An overview of biomass thermochemical conversion technologies in Malaysia. Sci Total Environ 680:105-123. https://doi.org/10.1016/j.scitotenv.2019.04.211

Chen WH, Kuo PC (2011) Torrefaction and co-torrefaction characterization of hemicellulose, cellulose and lignin as well as torrefaction of some basic constituents in biomass. Energy 36:803-811. https://doi.org/10.1016/j.energy.2010.12.036

Chen WH et al (2012a) An experimental analysis on property and structure variations of agricultural wastes undergoing torrefaction. Appl Energy 100:318-325. https://doi.org/10.1016/j.apene rgy.2012.05.056

Chen WH et al (2012b) Torrefied biomasses in a drop tube furnace to evaluate their utility in blast furnaces. Biores Technol 111:433438. https://doi.org/10.1016/j.biortech.2012.01.163
Chen WH et al (2013) Biomass torrefaction characteristics in inert and oxidative atmospheres at various superficial velocities. Biores Technol 146:152-160. https://doi.org/10.1016/j.biortech.2013. 07.064

Chen WH et al (2014a) Thermal decomposition dynamics and severity of microalgae residues in torrefaction. Biores Technol 169:258 264. https://doi.org/10.1016/j.biortech.2014.06.086

Chen WH et al (2014b) Thermal characterization of oil palm fiber and eucalyptus in torrefaction. Energy 71:40-48. https://doi.org/10. 1016/j.energy.2014.03.117

Chen WH et al (2014c) Non-oxidative and oxidative torrefaction characterization and SEM observations of fibrous and ligneous biomass. Appl Energy 114:104-113. https://doi.org/10.1016/j.apene rgy.2013.09.045

Chen P et al (2015) Microwave-assisted thermochemical conversion of biomass for biofuel production. Biofuels and Biorefineries 3:83-98. https://doi.org/10.1007/978-94-017-9612-5_5

Chen WH et al (2021) Progress in biomass torrefaction: principles, applications and challenges. Prog Energy Combust Sci 82:100887-100887. https://doi.org/10.1016/j.pecs.2020.100887

Chiaramonti D et al (2011) 2nd generation lignocellulosic bioethanol: is torrefaction a possible approach to biomass pretreatment? Biomass Conversion and Biorefinery 1:9-15. https://doi.org/10. 1007/s13399-010-0001-z

Chintala V (2018) Production, upgradation and utilization of solar assisted pyrolysis fuels from biomass - a technical review. Renew Sustain Energy Rev 90:120-130. https://doi.org/10.1016/j.rser. 2018.03.066

Choi J et al (2014) Production of brown algae pyrolysis oils for liquid biofuels depending on the chemical pretreatment methods. Energy Convers Manage 86:371-378. https://doi.org/10.1016/j. enconman.2014.04.094

Choi JH et al (2017) Effects of water-washing Saccharina japonica on fast pyrolysis in a bubbling fluidized-bed reactor. Biomass Bioenerg 98:112-123. https://doi.org/10.1016/j.biombioe.2017.01.006

Chung ZL et al (2019) Life cycle assessment of waste cooking oil for biodiesel production using waste chicken eggshell derived $\mathrm{CaO}$ as catalyst via transesterification. Biocatal Agric Biotechnol 21:101317. https://doi.org/10.1016/j.bcab.2019.101317

Collotta $\mathrm{M}$ et al (2019) Critical indicators of sustainability for biofuels: an analysis through a life cycle sustainabilty assessment perspective. Renew Sustain Energy Rev 115:109358. https://doi.org/10. 1016/j.rser.2019.109358

Cusenza MA et al (2021) Energy and environmental assessment of residual bio-wastes management strategies. J Clean Prod 285:124815. https://doi.org/10.1016/j.jclepro.2020.124815

Da Silva MG et al (2021) Greenhouse gas emissions of rice strawto-methanol chain in Southern Brazil. J Environ Chem Eng 9:105202. https://doi.org/10.1016/j.jece.2021.105202

Dabros TMH et al (2018) Transportation fuels from biomass fast pyrolysis, catalytic hydrodeoxygenation, and catalytic fast hydropyrolysis. Prog Energy Combust Sci 68:268-309. https://doi.org/ 10.1016/j.pecs.2018.05.002

Dasan YK et al (2019) Life cycle evaluation of microalgae biofuels production: effect of cultivation system on energy, carbon emission and cost balance analysis. Sci Total Environ 688:112-128. https://doi.org/10.1016/j.scitotenv.2019.06.181

Demirbas A (2001) Yields of hydrogen-rich gaseous products via pyrolysis from selected biomass samples. Fuel 80:1885-1891. https://doi.org/10.1016/S0016-2361(01)00070-9

Demirbas A (2004) Combustion characteristics of different biomass fuels. Prog Energy Combust Sci 30:219-230. https://doi.org/10. 1016/j.pecs.2003.10.004

Demirbas A (2005) Potential applications of renewable energy sources, biomass combustion problems in boiler power systems and 
combustion related environmental issues. Prog Energy Combust Sci 31:171-192. https://doi.org/10.1016/j.pecs.2005.02.002

Demirbas T, Demirbas AH (2010) Bioenergy, green energy. biomass and biofuels. Energy Sources Part a-Recovery Utilization and Environmental Effects 32:1067-1075. https://doi.org/10.1080/ 15567030903058600

Derose K et al (2019) Integrated techno economic and life cycle assessment of the conversion of high productivity, low lipid algae to renewable fuels. Algal Res 38:101412. https://doi.org/10.1016/j. algal.2019.101412

Di Fulvio F et al (2019) Spatially explicit LCA analysis of biodiversity losses due to different bioenergy policies in the European Union. Sci Total Environ 651:1505-1516. https://doi.org/10.1016/j.scito tenv.2018.08.419

Díaz González CA, Pacheco Sandoval L (2020) Sustainability aspects of biomass gasification systems for small power generation. Renew Sustain Energy Rev 134:110180-110180. https://doi. org/10.1016/j.rser.2020.110180

Dupuis DP et al (2019) High-Octane Gasoline from biomass: experimental, economic, and environmental assessment. Appl Energy 241:25-33. https://doi.org/10.1016/j.apenergy.2019.02.064

Elliott DC et al (2014) Hydrocarbon liquid production from biomass via hot-vapor-filtered fast pyrolysis and catalytic hydroprocessing of the bio-oil. Energy Fuels 28:5909-5917. https://doi.org/ $10.1021 / \mathrm{ef} 501536 \mathrm{j}$

Erol M et al (2010) Calorific value estimation of biomass from their proximate analyses data. Renewable Energy 35:170-173. https:// doi.org/10.1016/j.renene.2009.05.008

Ertas M, Alma MH (2010) Pyrolysis of laurel (Laurus nobilis L.) extraction residues in a fixed-bed reactor: characterization of bio-oil and bio-char. J Anal Appl Pyrol 88:22-29. https://doi. org/10.1016/j.jaap.2010.02.006

Farooq A et al (2019) Enhanced stability of bio-oil and diesel fuel emulsion using Span 80 and Tween 60 emulsifiers. J Environ Manage 231:694-700. https://doi.org/10.1016/j.jenvman.2018. 10.098

Farrell C et al (2019) Assessment of the energy recovery potential of waste Photovoltaic (PV) modules. Sci Rep 9:5267. https://doi. org/10.1038/s41598-019-41762-5

Farrell CC et al (2020) Technical challenges and opportunities in realising a circular economy for waste photovoltaic modules. Renewable Sustain Energy Rev. https://doi.org/10.1016/j.rser. 2020.109911

Fawzy S et al (2020) Strategies for mitigation of climate change: a review. Environ Chem Lett 18:2069-2094. https://doi.org/10. 1007/s10311-020-01059-w

Fawzy $S$ et al (2021) Industrial biochar systems for atmospheric carbon removal: a review. Environ Chem Lett. https://doi.org/10.1007/ s10311-021-01210-1

Feng Q, Lin Y (2017) Integrated processes of anaerobic digestion and pyrolysis for higher bioenergy recovery from lignocellulosic biomass: a brief review. Renew Sustain Energy Rev 77:1272-1287. https://doi.org/10.1016/j.rser.2017.03.022

Ferrera-Lorenzo N et al (2014) Pyrolysis characteristics of a macroalgae solid waste generated by the industrial production of AgarAgar. J Anal Appl Pyrol 105:209-216. https://doi.org/10.1016/j. jaap.2013.11.006

Fouilland T et al (2010) Recent advances in fluidized bed technology in biomass processes. Biofuels 1:409-433. https://doi.org/10. $4155 / \mathrm{bfs} .10 .20$

Friedl A et al (2005) Prediction of heating values of biomass fuel from elemental composition. Anal Chim Acta 544:191-198. https:// doi.org/10.1016/j.aca.2005.01.041

Fu J et al (2021) Assessing the sweet sorghum-based ethanol potential on saline-alkali land with DSSAT model and LCA approach. Biotechnol Biofuels. https://doi.org/10.1186/ s13068-021-01896-z

Ganesh Saratale R et al (2018) A critical review on anaerobic digestion of microalgae and macroalgae and co-digestion of biomass for enhanced methane generation. Bioresour Technol 262:319-332. https://doi.org/10.1016/j.biortech.2018.03.030

Gautam P et al (2020) Bio-methanol as a renewable fuel from waste biomass: current trends and future perspective. Fuel 273:117783117783. https://doi.org/10.1016/j.fuel.2020.117783

Gollakota ARK et al (2018) A review on hydrothermal liquefaction of biomass. Renew Sustain Energy Rev 81:1378-1392. https://doi. org/10.1016/j.rser.2017.05.178

Gunarathne V et al (2019) Biochar from municipal solid waste for resource recovery and pollution remediation. Environ Chem Lett 17:1225-1235. https://doi.org/10.1007/s10311-019-00866-0

Guo, Y., et al. A review of bio-oil production from hydrothermal liquefaction of algae. Vol. 48. Elsevier Ltd, 2015, pp. 776-790. https:// doi.org/10.1016/j.rser.2015.04.049

Guo, K., et al. 2019. Mechanism of preparation of platform compounds from lignocellulosic biomass liquefaction catalyzed by bronsted acid: a review. J Biores Bioproducts. 4, 202-213. https://doi.org/ 10.12162/jbb.v4i4.009

Gupta $S$ et al (2021) Advances in upgradation of pyrolysis bio-oil and biochar towards improvement in bio-refinery economics: A comprehensive review. Environ Technol Innovation. https://doi.org/ 10.1016/j.eti.2020.101276

Haghighi Mood S et al (2013) Lignocellulosic biomass to bioethanol, a comprehensive review with a focus on pretreatment. Renew Sustain Energy Rev 27:77-93. https://doi.org/10.1016/j.rser. 2013.06.033

Hagner M et al (2020) Performance of liquids from slow pyrolysis and hydrothermal carbonization in plant protection. Waste and Biomass Valorization 11:1005-1016. https://doi.org/10.1007/ s12649-018-00545-1

Hahn-Hägerdal B et al (2007) Towards industrial pentose-fermenting yeast strains. Appl Microbiol Biotechnol 74:937-953. https://doi. org/10.1007/s00253-006-0827-2

Hanchate $\mathrm{N}$ et al (2021) Biomass gasification using dual fluidized bed gasification systems: A review. J Clean Prod 280:123148123148. https://doi.org/10.1016/j.jclepro.2020.123148

Hassan EBM et al (2009) Characterization of fast pyrolysis bio-oils produced from pretreated pine wood. Appl Biochem Biotechnol 154:182-192. https://doi.org/10.1007/s12010-008-8445-3

Hassan NS et al (2020) Biofuels and renewable chemicals production by catalytic pyrolysis of cellulose: a review. Environ Chem Lett 18:1625-1648. https://doi.org/10.1007/s10311-020-01040-7

Haykiri-Acma H (2003) Combustion characteristics of different biomass materials. Energy Conversion Manage. https://doi.org/10. 1016/S0196-8904(01)00200-X

Hazrat MA et al (2021) Techniques to improve the stability of biodiesel: a review. Environ Chem Lett. https://doi.org/10.1007/ s10311-020-01166-8

Henrich E et al (2016) Fast pyrolysis of lignocellulosics in a twin screw mixer reactor. Fuel Process Technol 143:151-161. https://doi. org/10.1016/j.fuproc.2015.11.003

Hsu TC et al (2018) Upgrading of Jatropha-seed residue after mechanical extraction of oil via torrefaction. Energy 142:773-781. https://doi.org/10.1016/j.energy.2017.10.046

Igalavithana AD et al (2017) Heavy metal immobilization and microbial community abundance by vegetable waste and pine cone biochar of agricultural soils. Chemosphere 174:593-603. https:// doi.org/10.1016/j.chemosphere.2017.01.148

Im-Orb K, Arpornwichanop A (2020) Process and sustainability analyses of the integrated biomass pyrolysis, gasification, and 
methanol synthesis process for methanol production. Energy 193:116788. https://doi.org/10.1016/j.energy.2019.116788

ISO 14040:2006. Environmental management-Life cycle assessmentPrinciples and framework. https://www.iso.org/standard/37456. html

ISO 14044:2006. Environmental management-Life cycle assessmentRequirements and guidelines. https://www.iso.org/standard/ 38498.html

Izquierdo M, Querol X (2012) Leaching behaviour of elements from coal combustion fly ash: an overview. Int J Coal Geol 94:54-66. https://doi.org/10.1016/j.coal.2011.10.006

Jeswani HK et al (2020) Environmental and economic sustainability of biomass heat in the UK. Energ Technol 8:1901044. https://doi. org/10.1002/ente.201901044

Jiang X, Ellis N (2010) Upgrading bio-oil through emulsification with biodiesel: mixture production. Energy Fuels 24:1358-1364. https://doi.org/10.1021/ef9010669

Kainthola J et al (2019) A review on enhanced biogas production from anaerobic digestion of lignocellulosic biomass by different enhancement techniques. Process Biochem 84:81-90. https://doi. org/10.1016/j.procbio.2019.05.023

Kalbar PP et al (2017) Weighting and aggregation in life cycle assessment: do present aggregated single scores provide correct decision support? J Ind Ecol 21:1591-1600. https://doi.org/10.1111/ jiec. 12520

Kaloudas D et al (2021) Lignocellulose, algal biomass, biofuels and biohydrogen: a review. Environ Chem Lett. https://doi.org/10. 1007/s10311-021-01213-y

Kargbo H et al (2021) "Drop-in" fuel production from biomass: critical review on techno-economic feasibility and sustainability. Renew Sustain Energy Rev 135:110168-110168. https://doi.org/10. 1016/j.rser.2020.110168

Karimi S et al (2021) Processes and separation technologies for the production of fuel-grade bioethanol: a review. Environ Chem Lett. https://doi.org/10.1007/s10311-021-01208-9

Karpagam R et al (2021) Review on integrated biofuel production from microalgal biomass through the outset of transesterification route: a cascade approach for sustainable bioenergy. Sci Total Environ. https://doi.org/10.1016/j.scitotenv.2020.144236

Kasmuri NH et al (2017) Process system engineering aspect of bioalcohol fuel production from biomass via pyrolysis: an overview. Renew Sustain Energy Rev 79:914-923. https://doi.org/ 10.1016/j.rser.2017.05.182

Khodaei $\mathrm{H}$ et al (2015) An overview of processes and considerations in the modelling of fixed-bed biomass combustion. Energy 88:946972. https://doi.org/10.1016/j.energy.2015.05.099

Krzyżaniak M et al (2019) Life cycle assessment of poplar production: Environmental impact of different soil enrichment methods. J Clean Prod 206:785-796. https://doi.org/10.1016/j.jclepro.2018. 09.180

Kumar R et al (2020) Lignocellulose biomass pyrolysis for bio-oil production: a review of biomass pre-treatment methods for production of drop-in fuels. Renew Sustain Energy Rev. https://doi. org/10.1016/j.rser.2020.109763

Kwon, E. E., et al. 2019. Pyrolysis of waste feedstocks in $\mathrm{CO}_{2}$ for effective energy recovery and waste treatment. Journal of $\mathrm{CO}_{2}$ Utilization. 31, 173-180. https://doi.org/10.1016/j.jcou.2019.03.015

Lan K et al (2020) Life cycle analysis of decentralized preprocessing systems for fast pyrolysis biorefineries with blended feedstocks in the southeastern united states. Energ Technol 8:1900850. https:// doi.org/10.1002/ente. 201900850

Lask J et al (2020) Comparative environmental and economic life cycle assessment of biogas production from perennial wild plant mixtures and maize ( Zea mays L.) in southwest Germany. GCB Bioenergy 12:571-585. https://doi.org/10.1111/gcbb.12715
Lavanya M et al (2016) Hydrothermal liquefaction of freshwater and marine algal biomass: A novel approach to produce distillate fuel fractions through blending and co-processing of biocrude with petrocrude. Biores Technol 203:228-235. https://doi.org/ 10.1016/j.biortech.2015.12.013

Lewandowski I et al (2000) Miscanthus: European experience with a novel energy crop. Biomass Bioenergy 19:209-227. https://doi. org/10.1016/S0961-9534(00)00032-5

Li B et al (2016) Preparation and characterization of bark-derived phenol formaldehyde foams. RSC Adv 6:40975-40981. https://doi. org/10.1039/c6ra05392k

Li HW et al (2017) Highly efficient liquefaction of wheat straw for the production of bio-polyols and bio-based polyurethane foams. Ind Crops Prod 109:426-433. https://doi.org/10.1016/j.indcrop. 2017.08.060

Li Y et al (2021) Exergy analysis of renewable light olefin production system via biomass gasification and methanol synthesis. Int $\mathrm{J}$ Hydrogen Energy 46:3669-3683. https://doi.org/10.1016/j.ijhyd ene.2020.10.213

Lin Y, Tanaka S (2006) Ethanol fermentation from biomass resources: Current state and prospects. Appl Microbiol Biotechnol 69:627642. https://doi.org/10.1007/s00253-005-0229-x

Liu K et al (2015) Butanol production from hydrothermolysis-pretreated switchgrass: quantification of inhibitors and detoxification of hydrolyzate. Biores Technol 189:292-301. https://doi.org/ 10.1016/j.biortech.2015.04.018

López Barreiro D et al (2015) Hydrothermal liquefaction of microalgae: effect on the product yields of the addition of an organic solvent to separate the aqueous phase and the biocrude oil. Algal Res 12:206-212. https://doi.org/10.1016/j.algal.2015.08.025

Łukajtis R et al (2018) Hydrogen production from biomass using dark fermentation. Renewable Sustain Energy Rev. 91:665-694. https://doi.org/10.1016/j.rser.2018.04.043

Luo $\mathrm{S}$ et al (2009) Hydrogen-rich gas from catalytic steam gasification of biomass in a fixed bed reactor: influence of particle size on gasification performance. Int J Hydrogen Energy 34:1260-1264. https://doi.org/10.1016/j.ijhydene.2008.10.088

Lv PM et al (2004) An experimental study on biomass air-steam gasification in a fluidized bed. Biores Technol 95:95-101. https://doi. org/10.1016/j.biortech.2004.02.003

Lynam JG et al (2011) Acetic acid and lithium chloride effects on hydrothermal carbonization of lignocellulosic biomass. Biores Technol 102:6192-6199. https://doi.org/10.1016/j.biortech.2011. 02.035

Marcilla A et al (2013) A review of thermochemical conversion of microalgae. Renew Sustain Energy Rev 27:11-19. https://doi. org/10.1016/j.rser.2013.06.032

Margeot A et al (2009) New improvements for lignocellulosic ethanol. Curr Opin Biotechnol 20:372-380. https://doi.org/10.1016/j.copbio.2009.05.009

Martillo Aseffe JA et al (2021) The corn cob gasification-based renewable energy recovery in the life cycle environmental performance of seed-corn supply chain: an Ecuadorian case study. Renewable Energy 163:1523-1535. https://doi.org/10.1016/j.renene.2020. 10.053

Martin MA (2010) First generation biofuels compete. New Biotechnol 27:596-608. https://doi.org/10.1016/j.nbt.2010.06.010

Martin JA et al (2014) Maximizing the stability of pyrolysis oil/diesel fuel emulsions. Energy Fuels 28:5918-5929. https://doi.org/10. $1021 /$ ef5015583

Martin-Lara MA et al (2017) Torrefaction of olive tree pruning: effect of operating conditions on solid product properties. Fuel 202:109-117. https://doi.org/10.1016/j.fuel.2017.04.007

Matheri AN et al (2018) Quantitative characterization of carbonaceous and lignocellulosic biomass for anaerobic digestion. Renew 
Sustain Energy Rev 92:9-16. https://doi.org/10.1016/j.rser.2018. 04.070

Mehrpooya M et al (2018) Model development and energy and exergy analysis of the biomass gasification process (Based on the various biomass sources). Renew Sustain Energy Rev 91:869-887. https://doi.org/10.1016/j.rser.2018.04.076

Mendecka B et al (2020) Energy recovery from olive pomace by hydrothermal carbonization on hypothetical industrial scale: a LCA perspective. Waste and Biomass Valorization 11:5503-5519. https://doi.org/10.1007/s12649-020-01212-0

Meng JJ et al (2014) Toward understanding of bio-oil aging: accelerated aging of bio-oil fractions. ACS Sustain Chem Eng 2:20112018. https://doi.org/10.1021/sc500223e

Mika LT et al (2018) Catalytic conversion of carbohydrates to initial platform chemicals: chemistry and sustainability. Chem Rev 118:505-613. https://doi.org/10.1021/acs.chemrev.7b00395

Mladenović M et al (2018) Denitrification techniques for biomass combustion. Renew Sustain Energy Rev 82:3350-3364. https://doi. org/10.1016/j.rser.2017.10.054

Mohammed MAA et al (2011) Air gasification of empty fruit bunch for hydrogen-rich gas production in a fluidized-bed reactor. Energy Convers Manage 52:1555-1561. https://doi.org/10.1016/j.encon man.2010.10.023

Mohammed IY et al (2017) Effects of pretreatments of napier grass with deionized water, sulfuric acid and sodium hydroxide on pyrolysis oil characteristics. Waste and Biomass Valorization 8:755-773. https://doi.org/10.1007/s12649-016-9594-1

Molino A et al (2018) Biofuels Production by Biomass Gasification: A Review. Energies. https://doi.org/10.3390/En11040811

Nag, R., et al. 2019. Anaerobic digestion of agricultural manure and biomass - Critical indicators of risk and knowledge gaps. science of the Total Environment. 690, 460-479. https://doi.org/ 10.1016/j.scitotenv.2019.06.512

Nagappan S et al (2021) Catalytic hydrothermal liquefaction of biomass into bio-oils and other value-added products - A review. Fuel. https://doi.org/10.1016/j.fuel.2020.119053

Nam H, Capareda S (2015) Experimental investigation of torrefaction of two agricultural wastes of different composition using RSM (response surface methodology). Energy 91:507-516. https://doi. org/10.1016/j.energy.2015.08.064

Nilsson, J., et al. 2020. Assessing the climate and eutrophication impacts of grass cultivation at five sites in Sweden. Acta Agriculturae Scandinavica, Section B - Soil \& Plant Science. 70, 605-619. https://doi.org/10.1080/09064710.2020.1822436

Ogura $\mathrm{T}$ et al (2016) Improvement of physical, chemical, and biological properties of aridisol from Botswana by the incorporation of torrefied biomass. Sci Rep. https://doi.org/10.1038/Srep28011

Osman AI et al (2020) Critical challenges in biohydrogen production processes from the organic feedstocks. Biomass Conver Biorefinery. https://doi.org/10.1007/s13399-020-00965-x

Osman AI et al (2021) Recent advances in carbon capture storage and utilisation technologies: a review. Environ Chem Lett 19:797849. https://doi.org/10.1007/s10311-020-01133-3

Osman AI (2020) Mass spectrometry study of lignocellulosic biomass combustion and pyrolysis with NOx removal. Renewable Energy 146:484-496. https://doi.org/10.1016/j.renene.2019.06.155

Osman AI et al (2019) Reusing, recycling and up-cycling of biomass: a review of practical and kinetic modelling approaches. Fuel Process Technol 192:179-202. https://doi.org/10.1016/j.fuproc. 2019.04.026

Paudel SR et al (2017) Pretreatment of agricultural biomass for anaerobic digestion: current state and challenges. Bioresour Technol 245:1194-1205. https://doi.org/10.1016/j.biortech.2017.08.182

Pedersen TH et al (2016) Continuous hydrothermal co-liquefaction of aspen wood and glycerol with water phase recirculation. Appl
Energy 162:1034-1041. https://doi.org/10.1016/j.apenergy.2015. 10.165

Peng L et al (2020) Biofuel production from microalgae: a review. Environ Chem Lett 18:285-297. https://doi.org/10.1007/ s10311-019-00939-0

Perkins G et al (2018) Process development status of fast pyrolysis technologies for the manufacture of renewable transport fuels from biomass. Renew Sustain Energy Rev 90:292-315. https:// doi.org/10.1016/j.rser.2018.03.048

Perkins G et al (2019) Recent advances in liquefaction technologies for production of liquid hydrocarbon fuels from biomass and carbonaceous wastes. Renew Sustain Energy Rev 115:109400109400. https://doi.org/10.1016/j.rser.2019.109400

Peter AP et al (2021) Microalgae for biofuels, wastewater treatment and environmental monitoring. Environ Chem Lett. https://doi. org/10.1007/s10311-021-01219-6

Pidtasang B et al (2013) Influence of alcohol addition on properties of bio-oil produced from fast pyrolysis of eucalyptus bark in a free-fall reactor. J Ind Eng Chem 19:1851-1857. https://doi.org/ 10.1016/j.jiec.2013.02.031

Pleanjai S, Gheewala SH (2009) Full chain energy analysis of biodiesel production from palm oil in Thailand. Appl Energy 86:S209S214. https://doi.org/10.1016/j.apenergy.2009.05.013

Plis A et al (2015) Thermochemical and kinetic analysis of the pyrolysis process in Cladophora glomerata algae. J Anal Appl Pyrol 115:166-174. https://doi.org/10.1016/j.jaap.2015.07.013

Pradhan P et al (2018) Production and utilization of fuel pellets from biomass: a review. Fuel Process Technol. https://doi.org/10. 1016/j.fuproc.2018.09.021

Priharto N et al (2020) Fast pyrolysis with fractional condensation of lignin-rich digested stillage from second-generation bioethanol production. J Anal Appl Pyrol. https://doi.org/10.1016/J.Jaap. 2019.104756

Qasim U et al (2020) Renewable cellulosic nanocomposites for food packaging to avoid fossil fuel plastic pollution: a review. Environ Chem Lett. https://doi.org/10.1007/s10311-020-01090-x

Quereshi, S., et al. 1 - Overview of sustainable fuel and energy technologies. In: S. Dutta, C. Mustansar Hussain, Eds.), Sustainable Fuel Technologies Handbook. Academic Press, 2021, pp. 3-25.https://doi.org/10.1016/B978-0-12-822989-7.00001-9

Quispe I et al (2019) Life Cycle Assessment of rice husk as an energy source. a Peruvian case study. J Clean Prod 209:1235-1244. https://doi.org/10.1016/j.jclepro.2018.10.312

Raheem A et al (2015) Thermochemical conversion of microalgal biomass for biofuel production. Renew Sustain Energy Rev 49:990999. https://doi.org/10.1016/j.rser.2015.04.186

Raveendran K, Ganesh A (1996) Heating value of biomass and biomass pyrolysis products. Fuel 75:1715-1720. https://doi.org/10.1016/ S0016-2361(96)00158-5

Reaño RL (2020) Assessment of environmental impact and energy performance of rice husk utilization in various biohydrogen production pathways. Biores Technol 299:122590. https://doi.org/ 10.1016/j.biortech.2019.122590

Rodriguez Correa C, Kruse A (2018) Supercritical water gasification of biomass for hydrogen production - review. The Journal of Supercritical Fluids 133:573-590. https://doi.org/10.1016/j.supflu.2017.09.019

Ross AB et al (2008) Classification of macroalgae as fuel and its thermochemical behaviour. Biores Technol 99:6494-6504. https:// doi.org/10.1016/j.biortech.2007.11.036

Sahu SG et al (2014) Coal-biomass co-combustion: An overview. Renew Sustain Energy Rev 39:575-586. https://doi.org/10. 1016/j.rser.2014.07.106

Salapa, I., et al. Torrefaction of Barley Straw for the Co-Production of Energy and Adsorbent Materials. Proceedings of the 4th World 
Congress on Mechanical, Chemical, and Material Engineering (MCM'18) Madrid, Spain - August 16 - 18, 2018 Paper No. ICCPE 108. 2018. https://doi.org/10.11159/iccpe18.108

Sami M et al (2001) Co-firing of coal and biomass fuel blends. Prog Energy Combust Sci 27:171-214. https://doi.org/10.1016/S03601285(00)00020-4

Saranya G, Ramachandra TV (2020) Life cycle assessment of biodiesel from estuarine microalgae. Energy Conversion and Management: x 8:100065. https://doi.org/10.1016/j.ecmx.2020.100065

Sawatdeenarunat C et al (2015) Anaerobic digestion of lignocellulosic biomass: Challenges and opportunities. Bioresour Technol 178:178-186. https://doi.org/10.1016/j.biortech.2014.09.103

Scarsella, M., et al. 2020. Heterogeneous catalysts for hydrothermal liquefaction of lignocellulosic biomass: A review. biomass and Bioenergy. 140, 105662-105662. https://doi.org/10.1016/j.biomb ioe. 2020.105662

Schievano A et al (2016) Electro-fermentation - merging electrochemistry with fermentation in industrial applications. Trends Biotechnol 34:866-878. https://doi.org/10.1016/j.tibtech.2016. 04.007

Schmidt Rivera XC et al (2020) Life cycle environmental sustainability of valorisation routes for spent coffee grounds: from waste to resources. Resour Conserv Recycl 157:104751. https://doi.org/ 10.1016/j.resconrec.2020.104751

Schonhoff A et al (2021) Environmental competitiveness evaluation by life cycle assessment for solid fuels generated from Sida hermaphrodita biomass. Biomass Bioenerg 145:105966. https://doi. org/10.1016/j.biombioe.2021.105966

Sekar M et al (2021) A review on the pyrolysis of algal biomass for biochar and bio-oil - Bottlenecks and scope. Fuel. https://doi. org/10.1016/j.fuel.2020.119190

Shahabuddin M et al (2020) A review on the production of renewable aviation fuels from the gasification of biomass and residual wastes. Bioresour Technol 312:123596-123596. https://doi.org/ 10.1016/j.biortech.2020.123596

Sharma, H. B., et al. Hydrothermal carbonization of renewable waste biomass for solid biofuel production: A discussion on process mechanism, the influence of process parameters, environmental performance and fuel properties of hydrochar. Vol. 123. Renewable and Sustainable Energy Reviews 2020, pp. 109761-109761. https://doi.org/10.1016/j.rser.2020.109761

Sheikh MMI et al (2013) Effect of torrefaction for the pretreatment of rice straw for ethanol production. J Sci Food Agric 93:31983204. https://doi.org/10.1002/jsfa.6155

Shen Y, Yoshikawa K (2013) Recent progresses in catalytic tar elimination during biomass gasification or pyrolysis - a review. Renew Sustain Energy Rev 21:371-392. https://doi.org/10.1016/j.rser. 2012.12.062

Shrestha S et al (2017) Biological strategies for enhanced hydrolysis of lignocellulosic biomass during anaerobic digestion: current status and future perspectives. Bioresour Technol 245:1245-1257. https://doi.org/10.1016/j.biortech.2017.08.089

Shrivastava P et al (2019) An experimental evaluation of engine performance and emisssion characteristics of $\mathrm{CI}$ engine operated with Roselle and Karanja biodiesel. Fuel. https://doi.org/10.1016/J. Fuel.2019.115652

Simon, J. M., 2019. A Zero Waste hierarchy for Europe. New tools for new times. From waste management to resource management.

Singh R et al (2016) Strategies for selection of thermo-chemical processes for the valorisation of biomass. Renewable Energy 98:226-237. https://doi.org/10.1016/j.renene.2016.03.023

Situmorang YA et al (2020) Small-scale biomass gasification systems for power generation $(<200 \mathrm{~kW}$ class): a review. Renew Sustain Energy Rev 117:109486-109486. https://doi.org/10.1016/j.rser. 2019.109486
Skoulou V et al (2008) Syngas production from olive tree cuttings and olive kernels in a downdraft fixed-bed gasifier. Int J Hydrogen Energy 33:1185-1194. https://doi.org/10.1016/j.ijhydene.2007. 12.051

Slade R et al (2014) Global bioenergy resources. Nature. Clim Change 4:99-105. https://doi.org/10.1038/nclimate2097

Solarte-Toro JC et al (2021) Thermochemical processing of woody biomass: A review focused on energy-driven applications and catalytic upgrading. Renew Sustain Energy Rev. https://doi.org/ 10.1016/j.rser.2020.110376

Song B et al (2021) Recent advances and challenges of inter-disciplinary biomass valorization by integrating hydrothermal and biological techniques. Renewable Sustain Energy Rev. https:// doi.org/10.1016/j.rser.2020.110370

Spatari S et al (2020) Environmental, exergetic and economic tradeoffs of catalytic- and fast pyrolysis-to-renewable diesel. Renewable Energy 162:371-380. https://doi.org/10.1016/j.renene.2020.08. 042

Sundaram V et al (2016) Understanding the impacts of AFEX TM pretreatment and densification on the fast pyrolysis of corn stover, prairie cord grass, and switchgrass. Appl Biochem Biotechnol 181:1060-1079. https://doi.org/10.1007/s12010-016-2269-3

Tanzer SE et al (2019) Lignocellulosic marine biofuel: technoeconomic and environmental assessment for production in Brazil and Sweden. J Clean Prod 239:117845. https://doi.org/10.1016/j.jclepro. 2019.117845

Thanapal SS et al (2014) Carbon dioxide torrefaction of woody biomass. Energy Fuels 28:1147-1157. https://doi.org/10.1021/ef402 2625

Thengane SK et al (2020) Life cycle assessment of rice husk torrefaction and prospects for decentralized facilities at rice mills. J Clean Prod 275:123177. https://doi.org/10.1016/j.jclepro.2020. 123177

Thomson R et al (2020) Clean syngas from small commercial biomass gasifiers; a review of gasifier development, recent advances and performance evaluation. Int J Hydrogen Energy 45:2108721111. https://doi.org/10.1016/j.jhydene.2020.05.160

Timonen K et al (2019) LCA of anaerobic digestion: emission allocation for energy and digestate. J Clean Prod 235:1567-1579. https://doi.org/10.1016/j.jclepro.2019.06.085

Toor SS et al (2011) Hydrothermal liquefaction of biomass: a review of subcritical water technologies. Energy 36:2328-2342. https:// doi.org/10.1016/j.energy.2011.03.013

Toor SS et al (2013) Hydrothermal liquefaction of Spirulina and Nannochloropsis salina under subcritical and supercritical water conditions. Biores Technol 131:413-419. https://doi.org/10.1016/j. biortech.2012.12.144

Ubando AT et al (2020) Life cycle assessment of torrefied microalgal biomass using torrefaction severity index with the consideration of up-scaling production. Renewable Energy 162:1113-1124. https://doi.org/10.1016/j.renene.2020.08.068

Ullah K et al (2015) Assessing the potential of algal biomass opportunities for bioenergy industry: A review. Fuel 143:414-423. https://doi.org/10.1016/j.fuel.2014.10.064

Vardon DR et al (2011) Chemical properties of biocrude oil from the hydrothermal liquefaction of Spirulina algae, swine manure, and digested anaerobic sludge. Biores Technol 102:8295-8303. https://doi.org/10.1016/j.biortech.2011.06.041

Variny, M., et al. 2021. Advances in Biomass Co-Combustion with Fossil Fuels in the European Context: A Review. Processes. 9, $100 \mathrm{https}: / / w w w . m d p i . c o m / 2227-9717 / 9 / 1 / 100$

Vassilev SV et al (2013) An overview of the composition and application of biomass ash. Part 1. phase-mineral and chemical composition and classification. Fuel 105:40-76. https://doi.org/10. 1016/j.fuel.2012.09.041 
Vicente ED, Alves CA (2018) An overview of particulate emissions from residential biomass combustion. Atmos Res 199:159-185. https://doi.org/10.1016/j.atmosres.2017.08.027

Volpe $M$ et al (2015) Upgrade of citrus waste as a biofuel via slow pyrolysis. J Anal Appl Pyrol 115:66-76. https://doi.org/10. 1016/j.jaap.2015.06.015

Wagner $\mathrm{M}$ et al (2019) Economic and environmental performance of miscanthus cultivated on marginal land for biogas production. GCB Bioenergy 11:34-49. https://doi.org/10.1111/gcbb.12567

Wainaina $S$ et al (2020) Resource recovery and circular economy from organic solid waste using aerobic and anaerobic digestion technologies. Bioresour Technol 301:122778-122778. https://doi. org/10.1016/j.biortech.2020.122778

Wang E, Shen Z (2013) A hybrid Data Quality Indicator and statistical method for improving uncertainty analysis in LCA of complex system - application to the whole-building embodied energy analysis. J Clean Prod 43:166-173. https://doi.org/10.1016/j. jclepro.2012.12.010

Wang H et al (2012) Effect of Acid, Steam Explosion, and Size Reduction Pretreatments on Bio-oil Production from Sweetgum, Switchgrass, and Corn Stover. Appl Biochem Biotechnol 167:285-297. https://doi.org/10.1007/s12010-012-9678-8

Wang $\mathrm{F}$ et al (2019a) Enhancing hydrogen production from biomass pyrolysis by dental-wastes-derived sodium zirconate. Int J Hydrogen Energy 44:23846-23855. https://doi.org/10.1016/j. ijhydene.2019.07.095

Wang C et al (2019b) Thermodynamics and LCA analysis of biomass supercritical water gasification system using external recycle of liquid residual. Renewable Energy 141:1117-1126. https://doi. org/10.1016/j.renene.2019.03.129

Wang C et al (2020a) A review of conversion of lignocellulose biomass to liquid transport fuels by integrated refining strategies. Fuel Process Technol 208:106485-106485. https://doi.org/10.1016/j. fuproc.2020.106485

Wang $\mathrm{G}$ et al (2020b) A review of recent advances in biomass pyrolysis. Energy Fuels 34:15557-15578. https://doi.org/10.1021/acs. energyfuels.0c03107

Xiao L et al (2021) Biochar promotes methane production during anaerobic digestion of organic waste. Environ Chem Lett. https:// doi.org/10.1007/s10311-021-01251-6

Xiu SN et al (2010) Effectiveness and mechanisms of crude glycerol on the biofuel production from swine manure through hydrothermal pyrolysis. J Anal Appl Pyrol 87:194-198. https://doi.org/10. 1016/j.jaap.2009.12.002
Xu XW et al (2018) High-quality fuel from the upgrading of heavy bio-oil by the combination of ultrasonic treatment and mutual solvent. Energy Fuels 32:3477-3487. https://doi.org/10.1021/ acs.energyfuels.7b03483

Yang LX et al (2016) Hydrothermal liquefaction of spent coffee grounds in water medium for bio-oil production. Biomass Bioenerg 86:191-198. https://doi.org/10.1016/j.biombioe.2016.02.005

Yang J et al (2019) A review on hydrothermal co-liquefaction of biomass. Appl Energy 250:926-945. https://doi.org/10.1016/j.apene rgy.2019.05.033

Yang W et al (2020) An overview of inorganic particulate matter emission from coal/biomass/MSW combustion: Sampling and measurement, formation, distribution, inorganic composition and influencing factors. Fuel Process Technol 213:106657-106657. https://doi.org/10.1016/j.fuproc.2020.106657

Yang Q et al (2021) Country-level potential of carbon sequestration and environmental benefits by utilizing crop residues for biochar implementation. Appl Energy 282:116275. https://doi.org/ 10.1016/j.apenergy.2020.116275

Zhang LH et al (2010) Overview of recent advances in thermo-chemical conversion of biomass. Energy Convers Manage 51:969-982. https://doi.org/10.1016/j.enconman.2009.11.038

Zhang L et al (2014) Optimization of a mixed additive and its effect on physicochemical properties of bio-oil. Chem Eng Technol 37:1181-1190. https://doi.org/10.1002/ceat.201300786

Zhang, M., Wu, H., 2014. Phase behavior and fuel properties of biooil/glycerol/methanol blends. energy and Fuels. 28, 4650-4656. https://doi.org/10.1021/ef501176z

Zhu L et al (2017) Upgrading the storage properties of bio-oil by adding a compound additive. Energy Fuels 31:6221-6227. https:// doi.org/10.1021/acs.energyfuels.7b00864

Zhu Y et al (2019) Water use of a biomass direct-combustion power generation system in China: a combination of life cycle assessment and water footprint analysis. Renew Sustain Energy Rev 115:109396. https://doi.org/10.1016/j.rser.2019.109396

Publisher's Note Springer Nature remains neutral with regard to jurisdictional claims in published maps and institutional affiliations. 